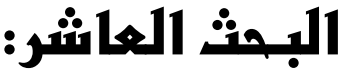

أساليب التنشئة الاجتهاعية الأسرية وعلاقتها بدافع الإنجاز لدى عينة هن

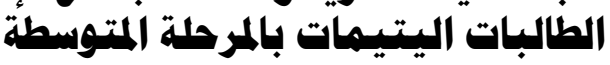

\section{: إلحاكاك}

د داطمتة بنت علي ناصرالدوسري

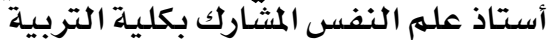

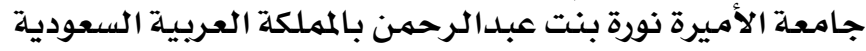





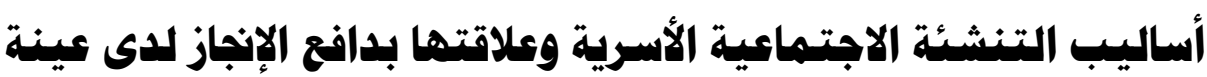

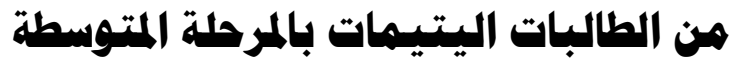

\author{
د/ فاطمت بنت علمي ناصر الللوسري

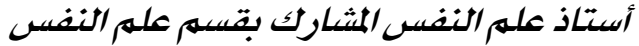

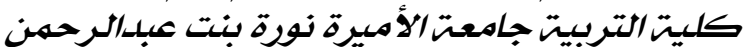

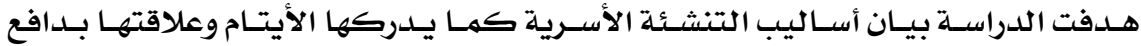

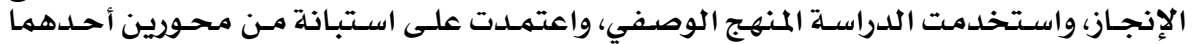

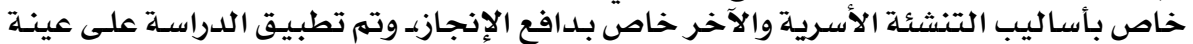

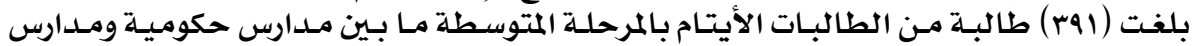

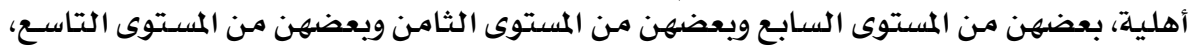

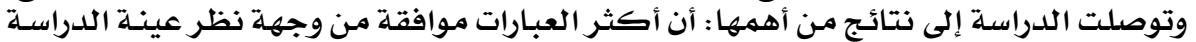

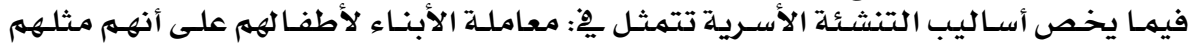

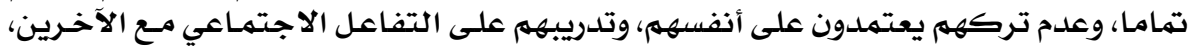

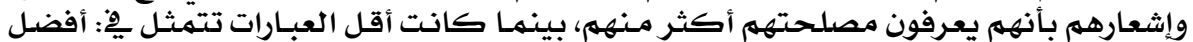

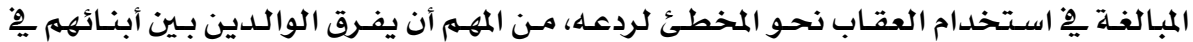

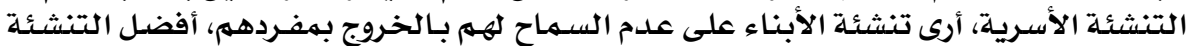

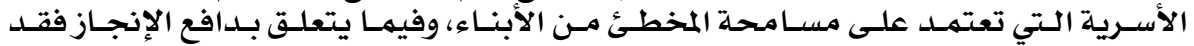

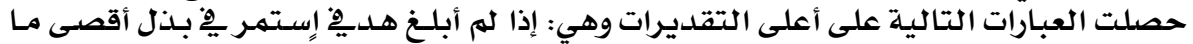

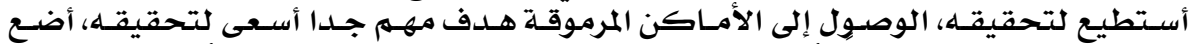

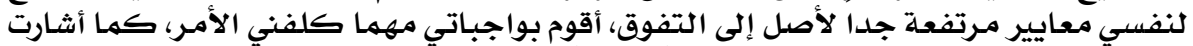

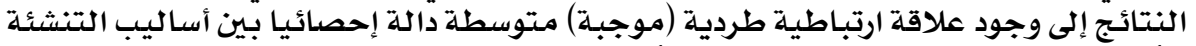

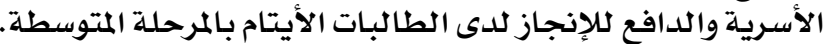

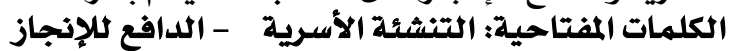

\section{Methods of Family Upbringing as Perceived by Orphans and Their Relation to Motivation of Achievement a Field Study on Middle School Students}

Dr. Fatima bint Ali Nasser Al-Dossary

\section{Abstract:}

The study aimed at explaining methods family upbringing as understood by orphans and their relation to motivation of achievement. The study used the descriptive method, and relied on a two-pronged questionnaire: one on methods of family upbringing and the other on motivation of achievement. The study was applied on a sample of (391) female students of middle school, between government schools and private schools: some of them are from the seventh level, some are from the eighth level and some are from the ninth level. The study reached the following results: The most agreeable statements from the point of view of the sample of the study regarding the methods of family upbringing are: the treatment of parents to their children as completely like them, not to be self-reliant, and to train them to socialize with others and to inform them that they know their best interest. The lesser

\section{rq 1}


words are: I prefer overuse the punishment towards the wrong to deter him, it is important for parents to distinguish between their children in family upbringing, I prefer in the upbringing of children not to let them out on their own, I prefer family upbringing based on the forgiveness of the sinner of children, For the sake of achievement, the following statements have the highest ratings: If I do not achieve my goal, I continue to do my utmost to reach the prestigious places, access to prestigious places is a very important goal I seek to achieve, I set myself very high standards of excellence, I do my duties whatever I need, I am trying to be distinguished among my classmates. The following statements have the lowest estimates: I plan constantly for my future, I identify constantly the weaknesses in my performance to treat them. Results indicate a positive statistically significant correlation between methods of family upbringing and motivation of achievement among middle school female orphans.

Keywords: Family Upbringing - Motivation of Achievement.

\section{•الرقدهمة:}

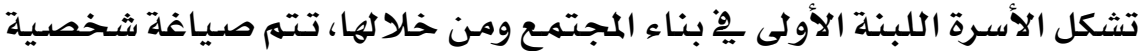

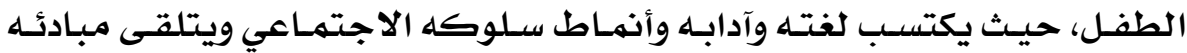

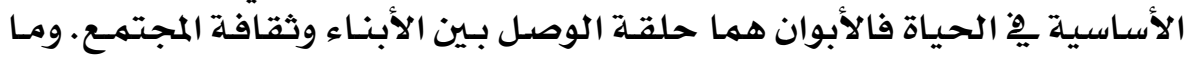

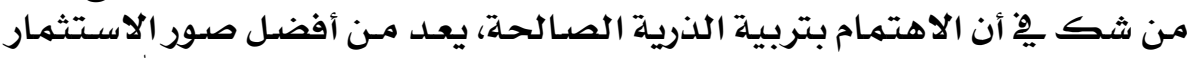

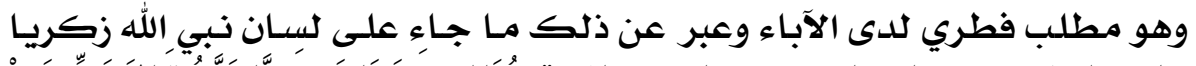

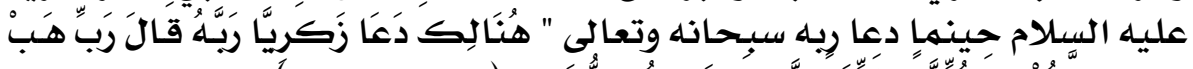

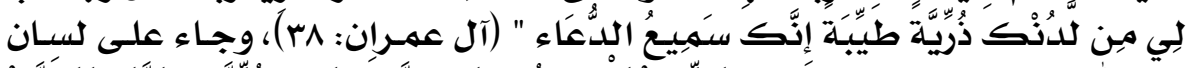

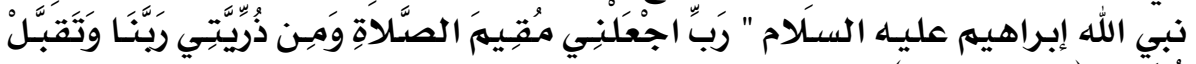
دُعَاًء " (إبراهيهم: •ع ).

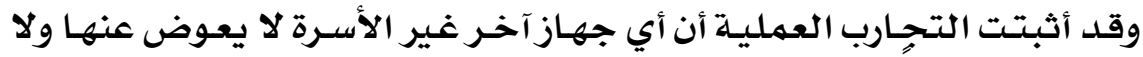

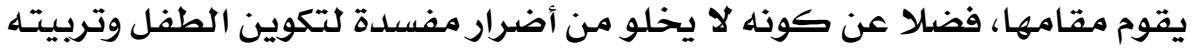

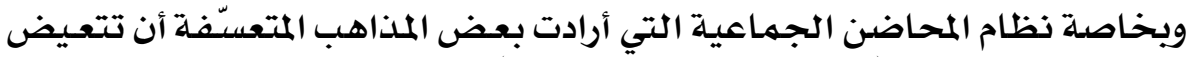

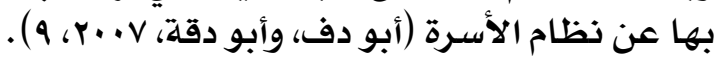

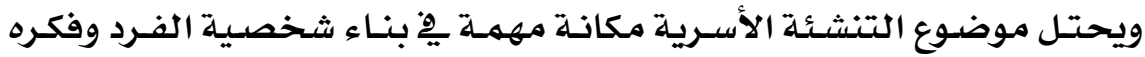

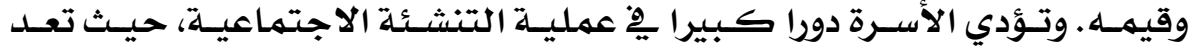

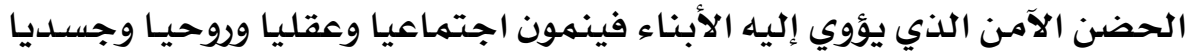

$$
\text { وعاطفيا يِ مختلف سني حياتهم. }
$$

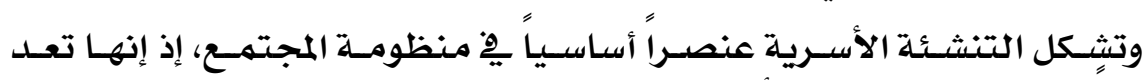

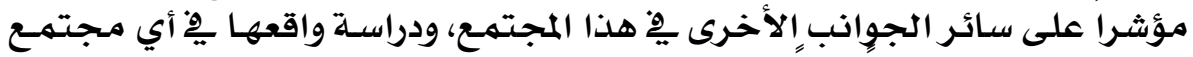

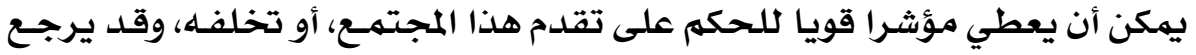

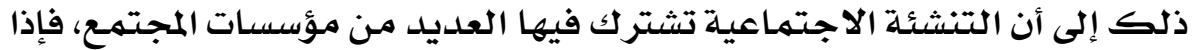




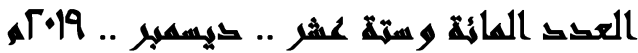

تحققت أهدافها وأعدت الشخهصية القادرة على مواجهة المتخيرات المختلفة، كان

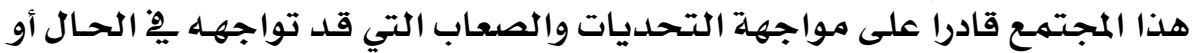

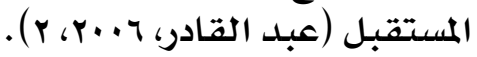

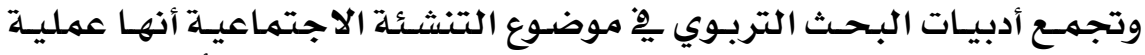

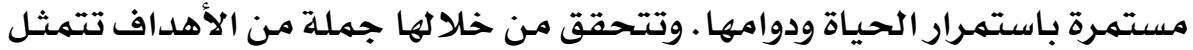

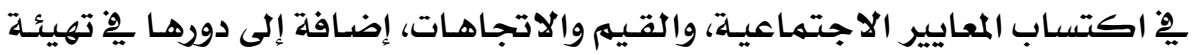

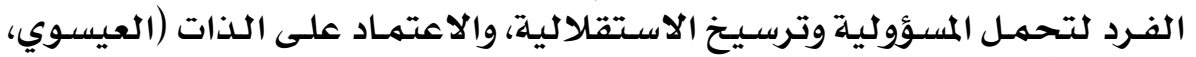
. $(\varepsilon r, r \cdot r$

وتعد الرعاية الوالدية لـلأبناء من أهم الأسـاليب التي يعتمد عليها يخ تأهيلهم

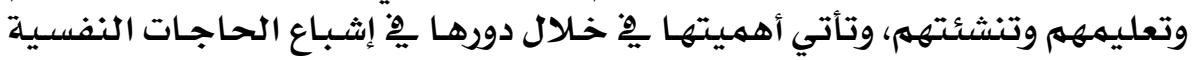

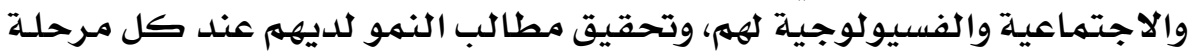

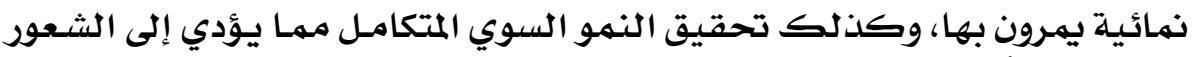

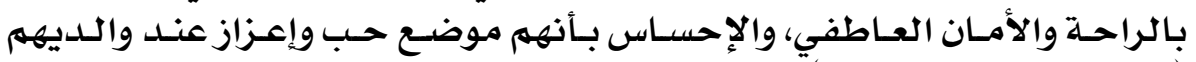

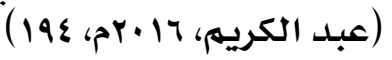

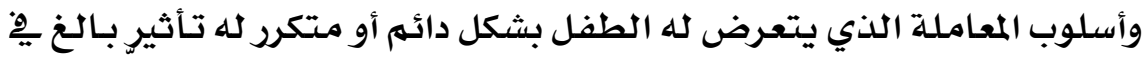

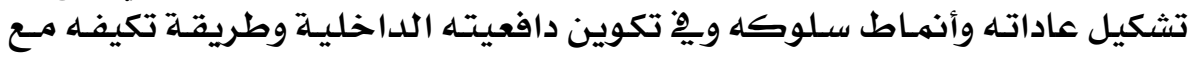

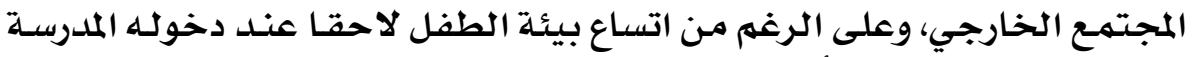

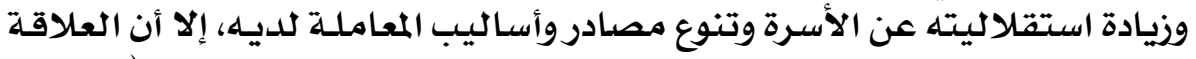

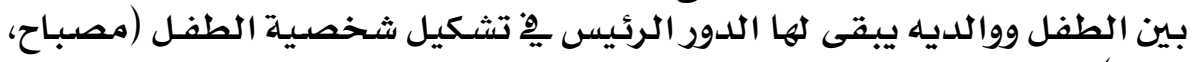
(r..)

ويهكن القـول بـأن الأسـرة تسـتخدم يخ عمليـة التتشـئهة الاجتهماعيـة لأطفا لها

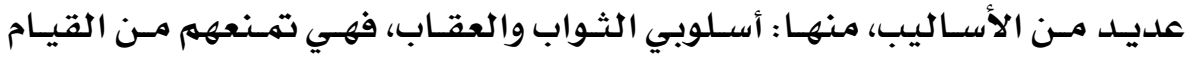

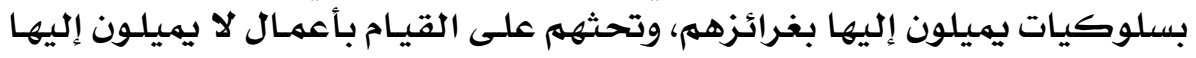

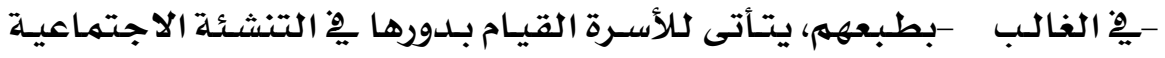

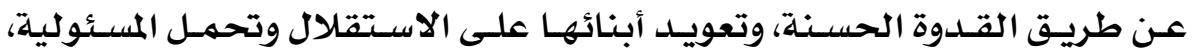

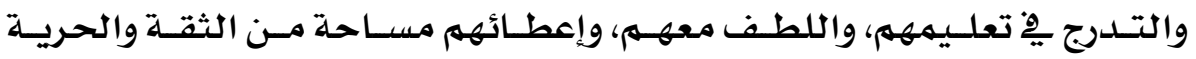

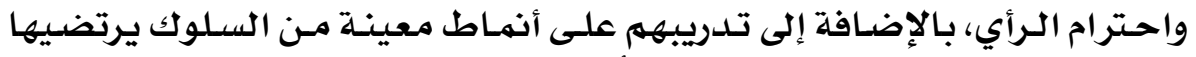

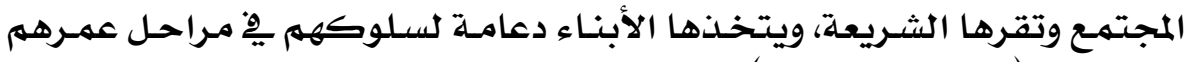

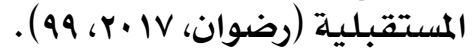

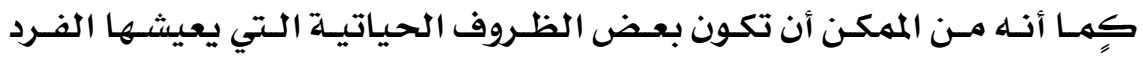

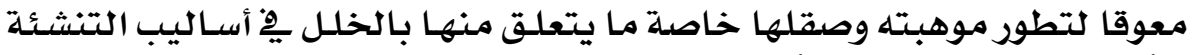

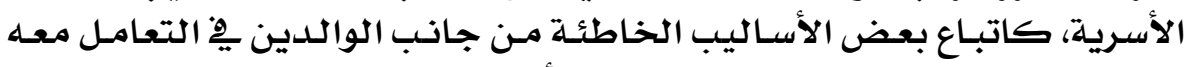

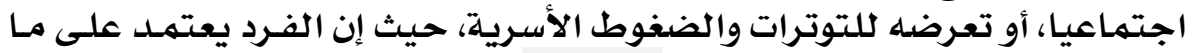




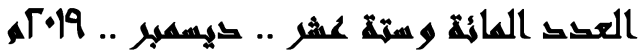

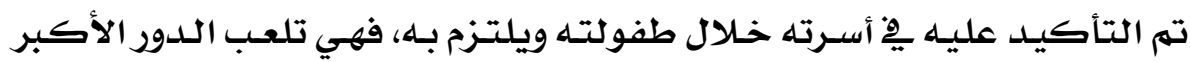

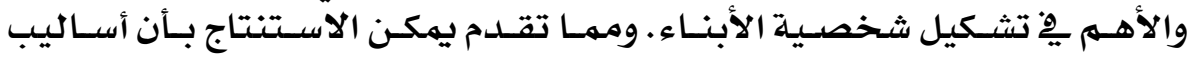

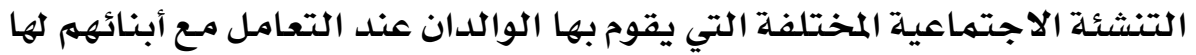

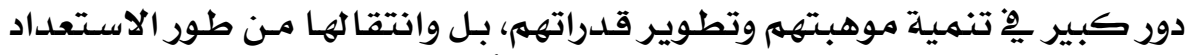

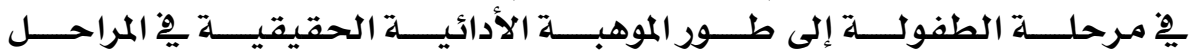

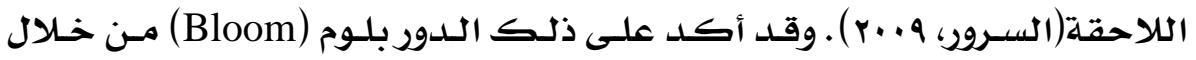

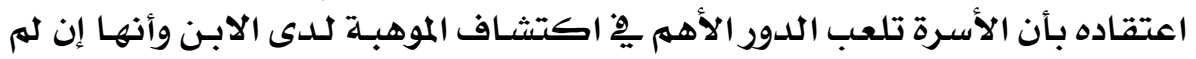

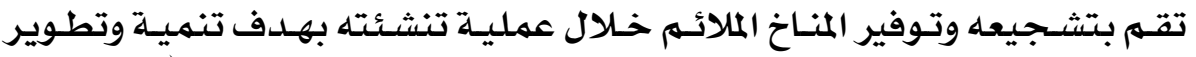

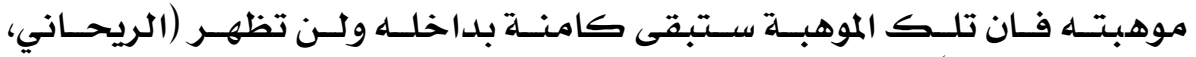

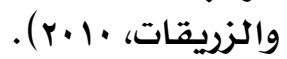

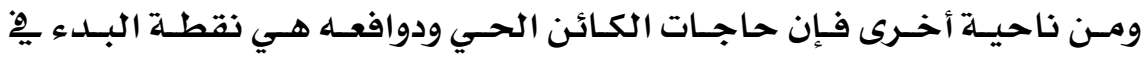

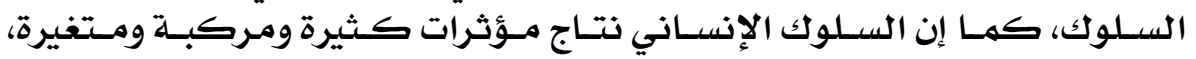

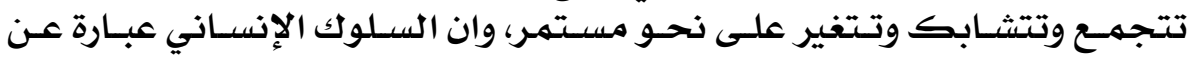

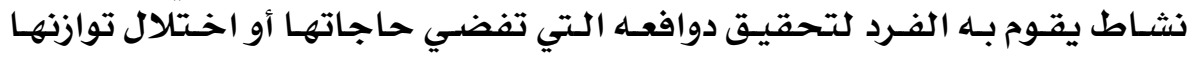

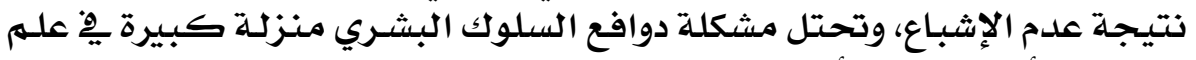

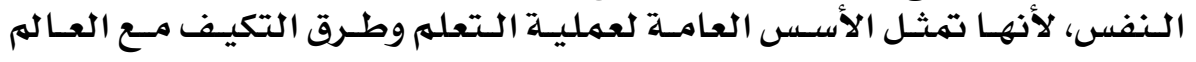

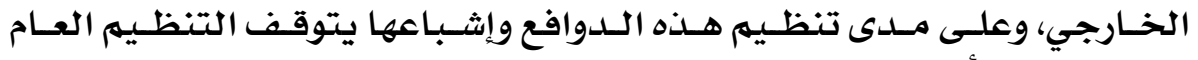

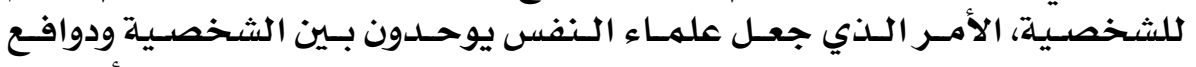

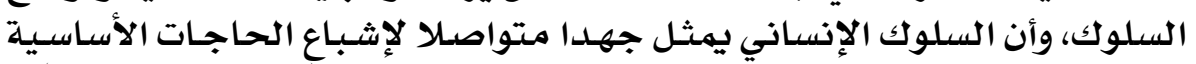

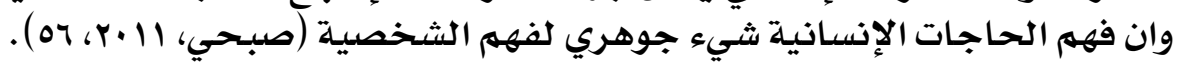

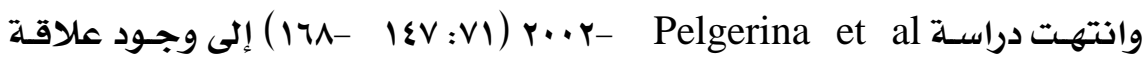

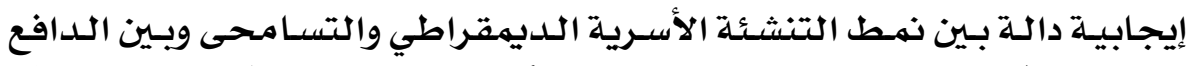

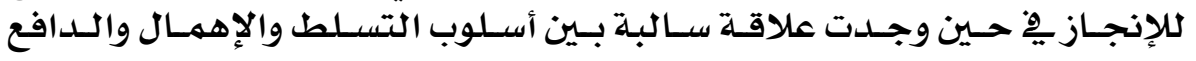
للإنجاز.

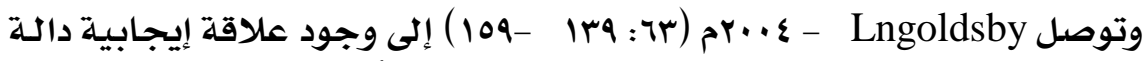

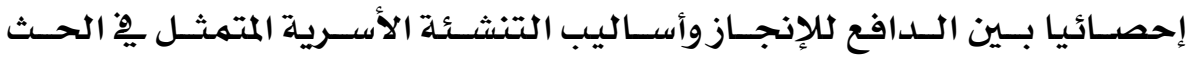

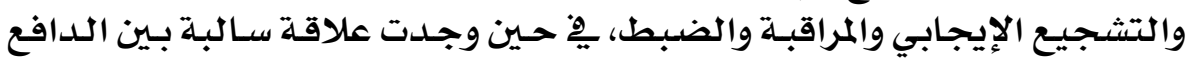

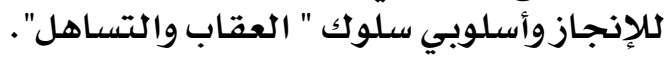

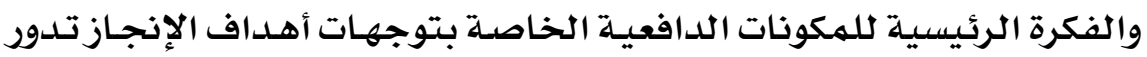

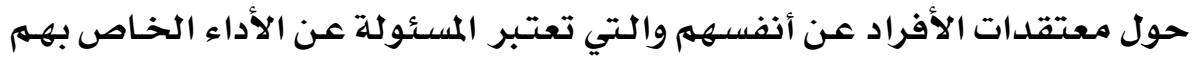

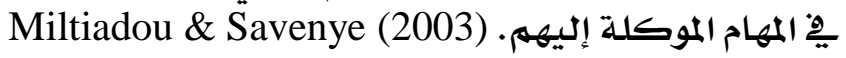

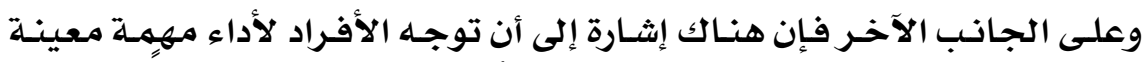

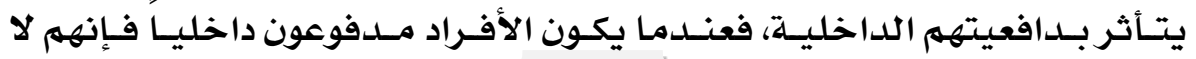


يحتاجون إلى محفزات لأن أداء العمل نفسـه ِِّهذ هذه الحالة يعتبر نوع من المكافأة

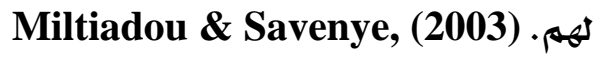

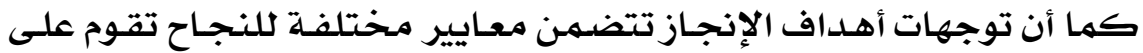

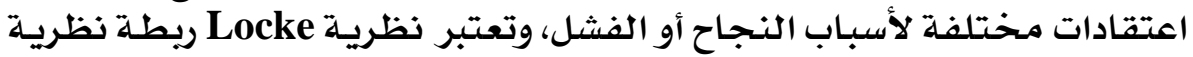

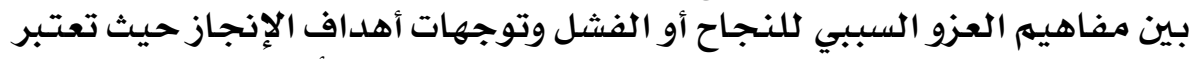

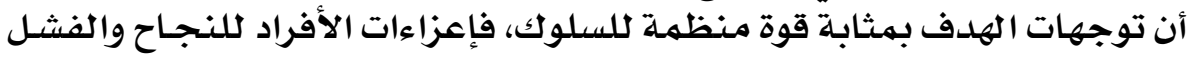

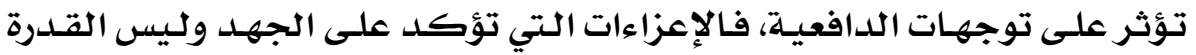

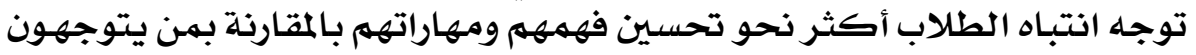

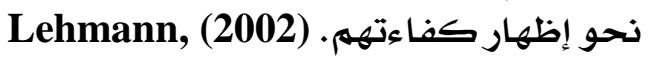

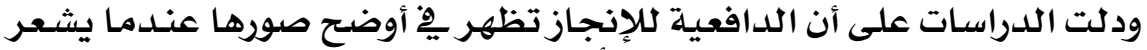

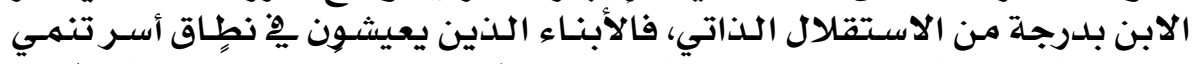

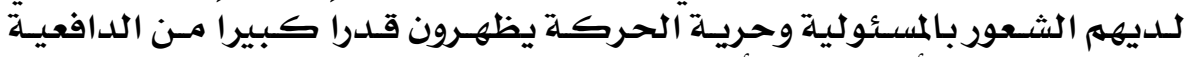

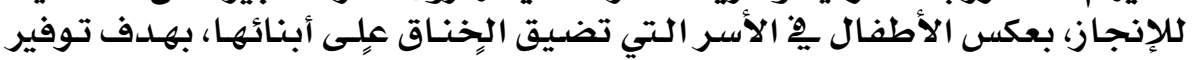

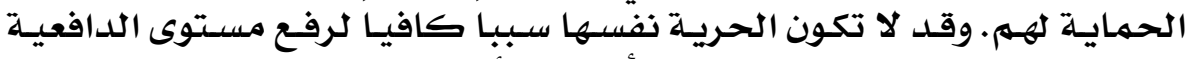

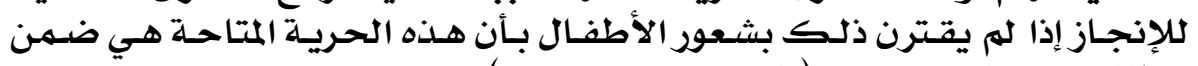

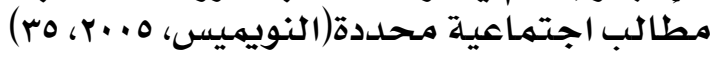

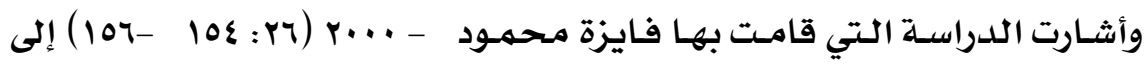

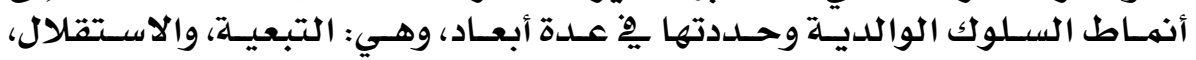

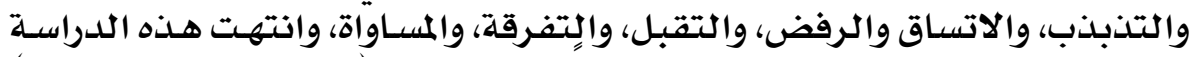

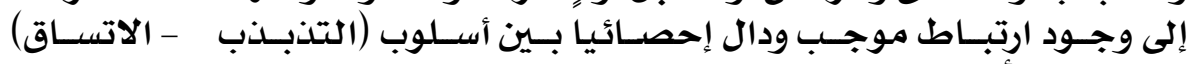

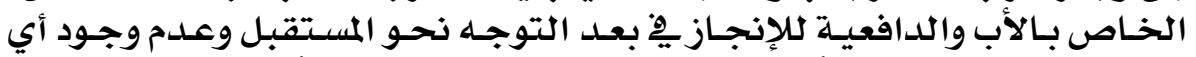

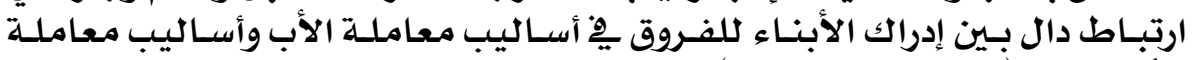

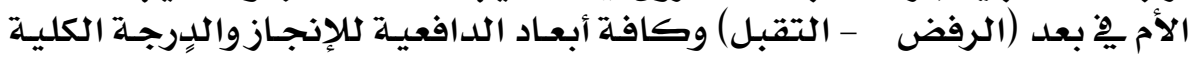

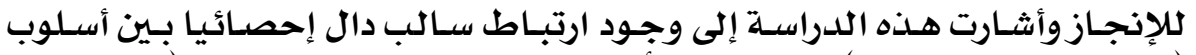

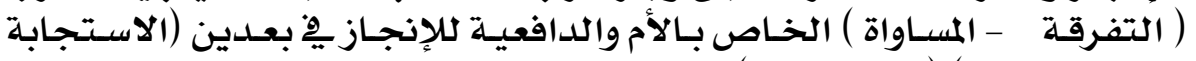
للنجاح، الفشل) (الاستقلاولية).

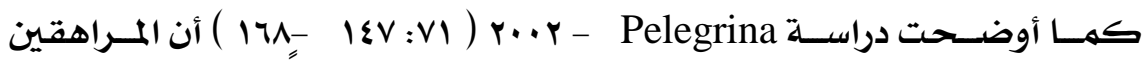

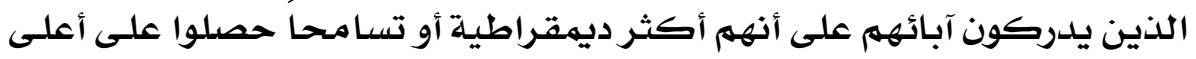

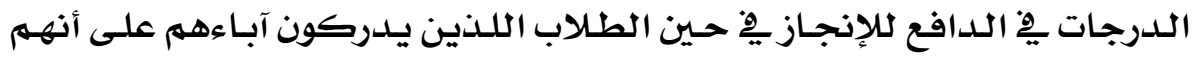

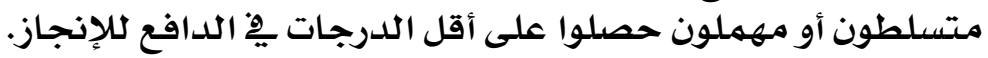

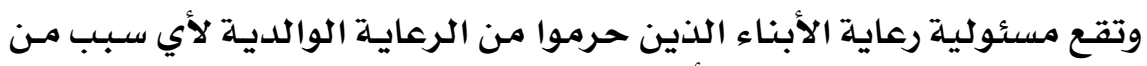

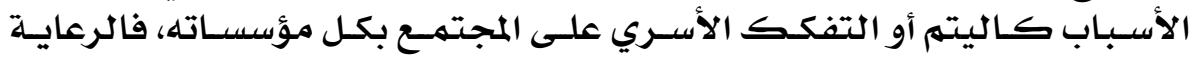

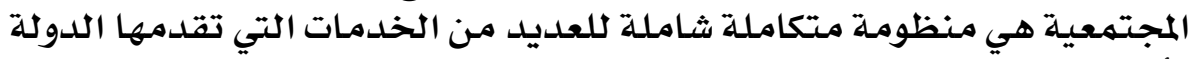

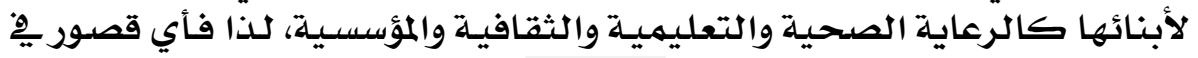




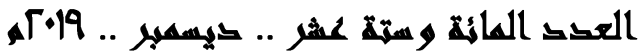

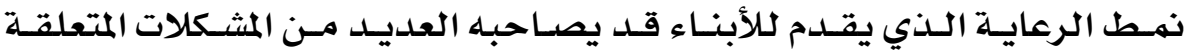

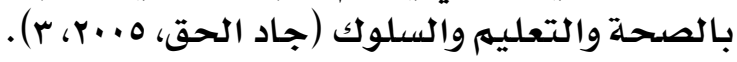

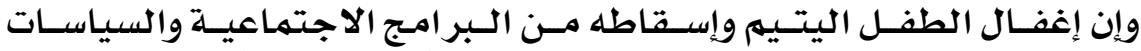

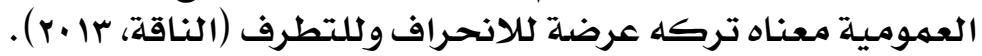

\section{• مشكلة الدراسة:}

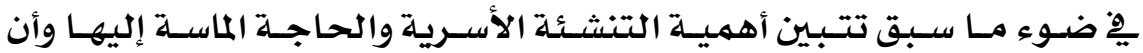

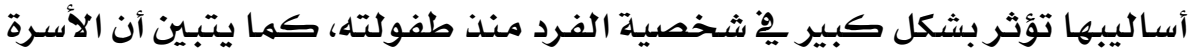

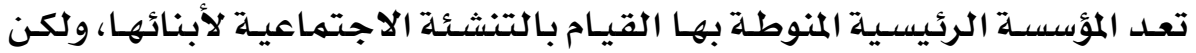

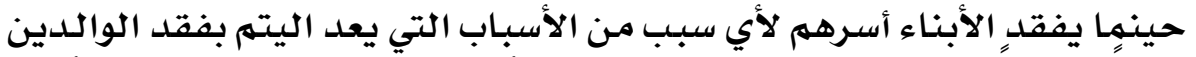

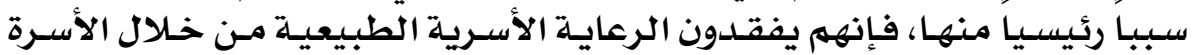

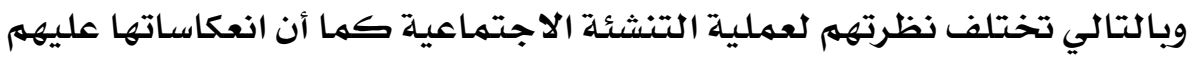

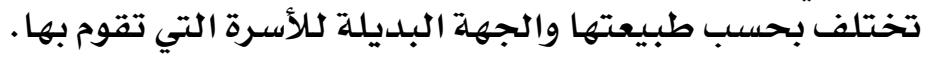

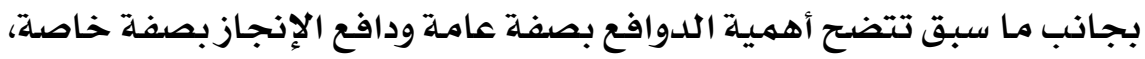

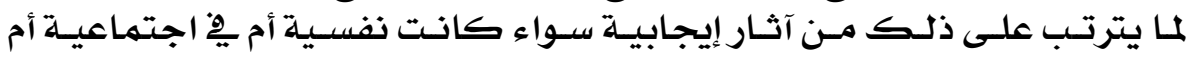

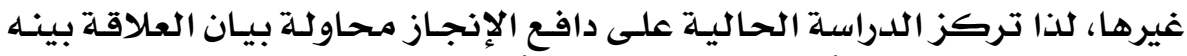

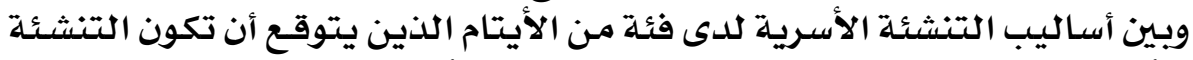

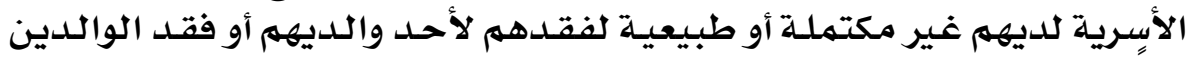
معا.

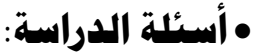

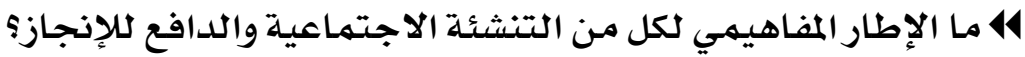

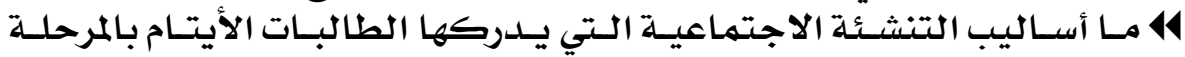

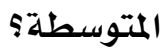

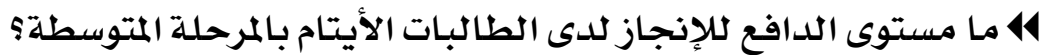
14

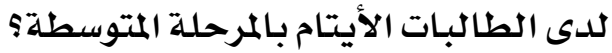

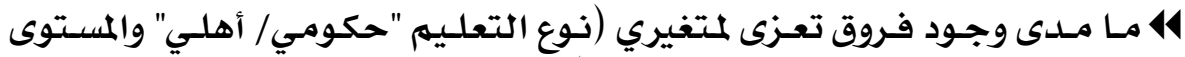

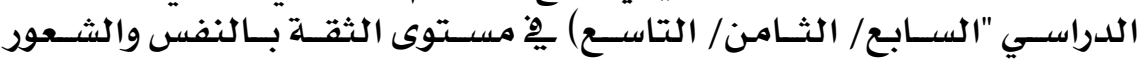

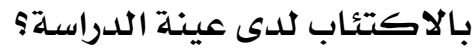
• أهداف الدراسة:

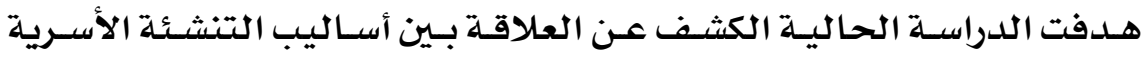

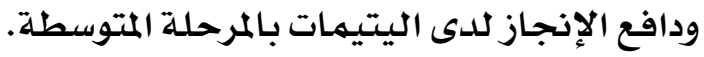

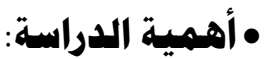
تنطلق أهمية الدراسة مـن عدة اعتبارات أهمها ما يلي: 
14 ندرة الدراسـات التي ريطت بين كل من أسـاليب التنشئية الاجتمهاعيـة والدافع

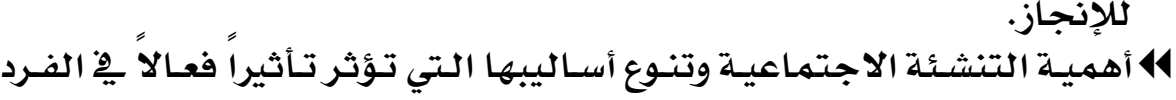

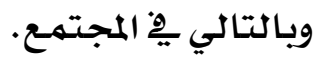

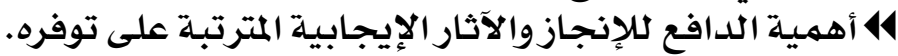

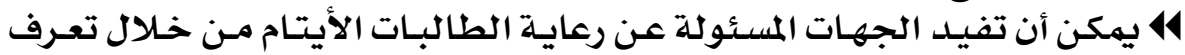

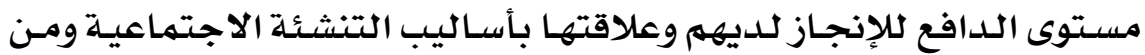

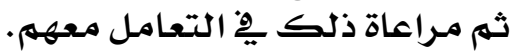

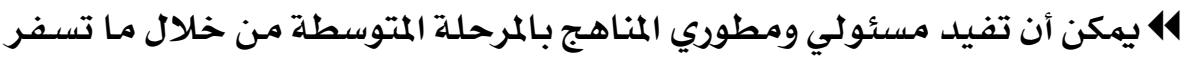

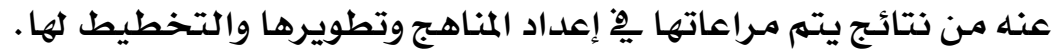

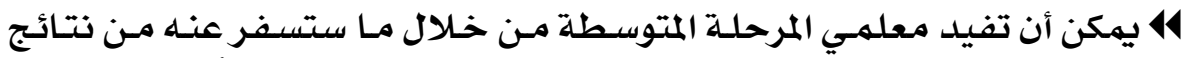

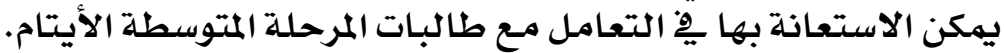

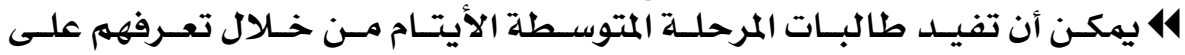

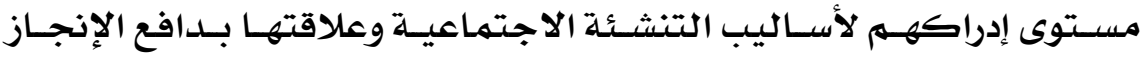

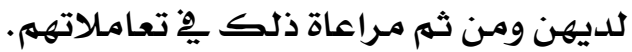

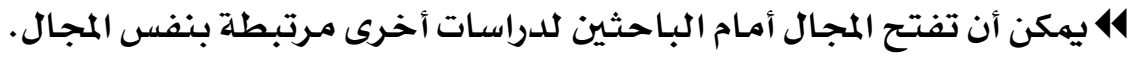
• مصالمات الدراسة: • التنشئة الأسرية:

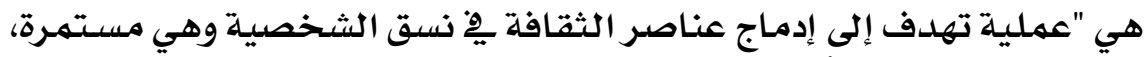

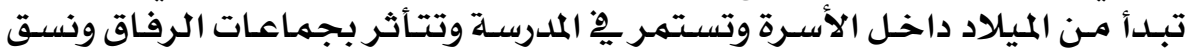

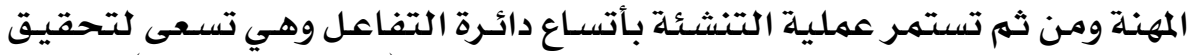

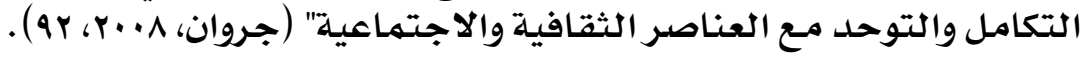

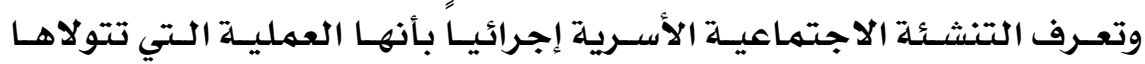

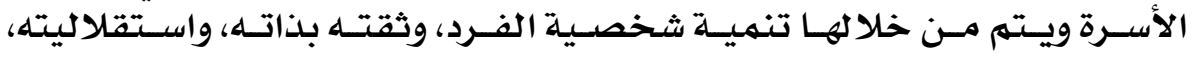

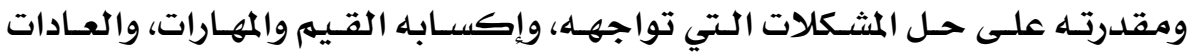

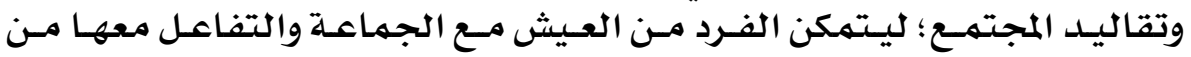

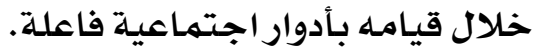

• أساليب التنشئة الأسرية:

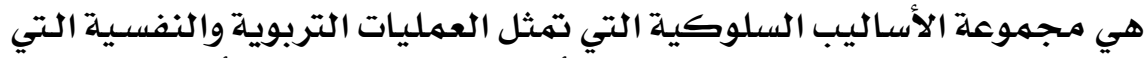

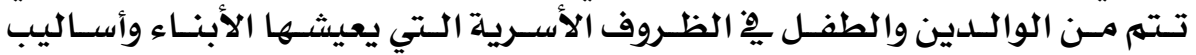

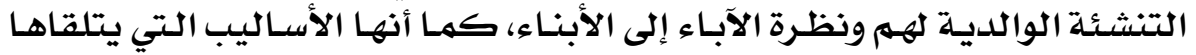

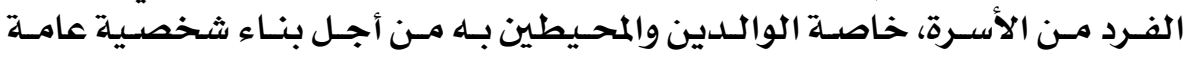

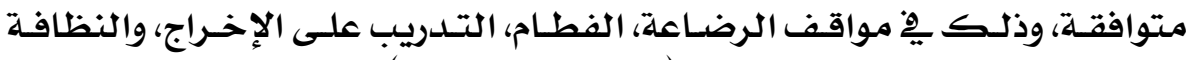

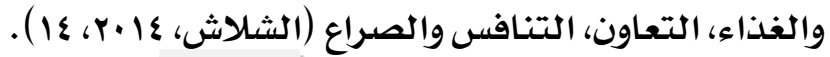




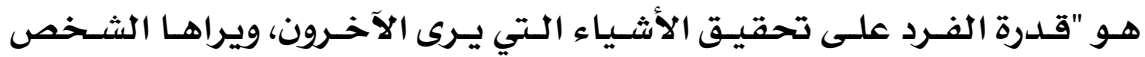

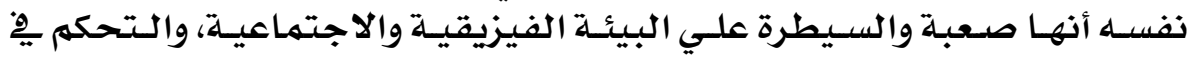

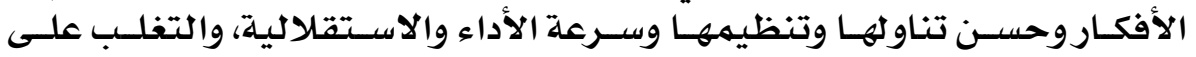

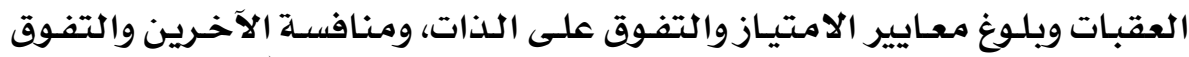

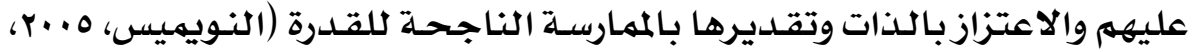

• الطالبات اليتيسمات بالمرحلة المتوسطة:

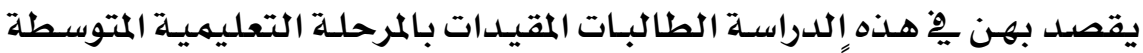

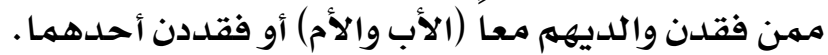
• عدود الدراسة:

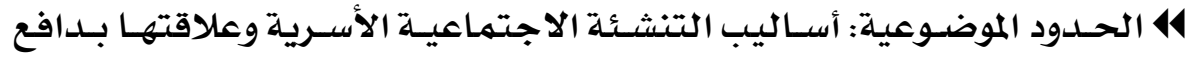
الإنجاز.

41 الحدود البشرية: طالبـات المرحلة المتوسطة الأيتام المحلددين بعينة الدراسلة.

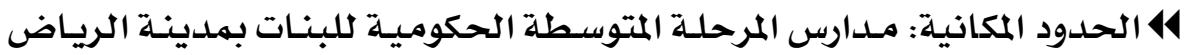

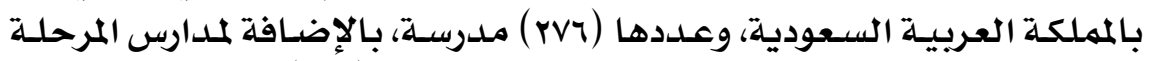

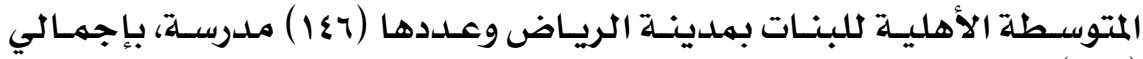

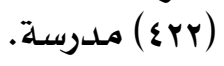

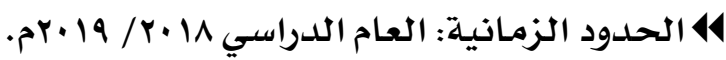
• دراسات سابقة:

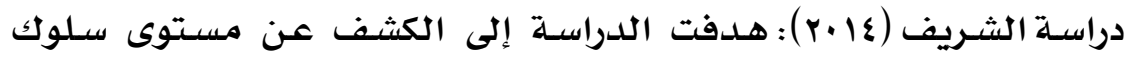

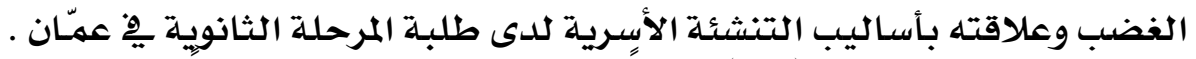

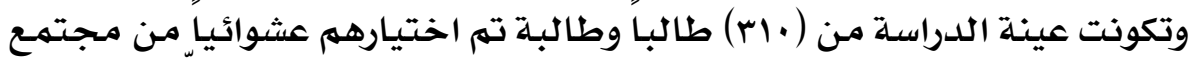

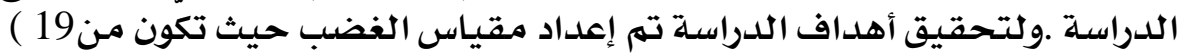

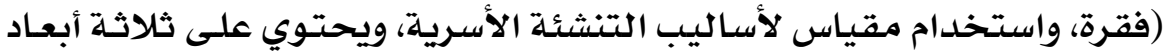

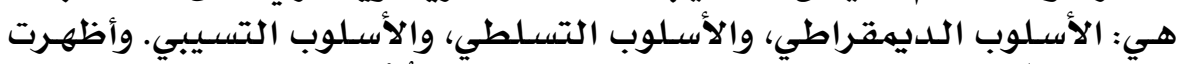

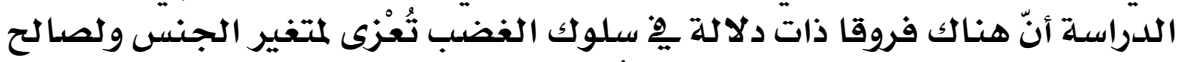

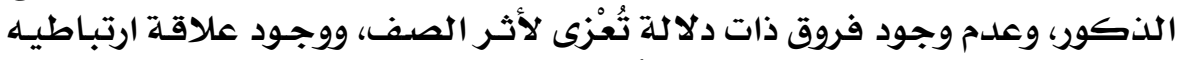

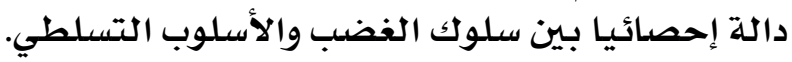

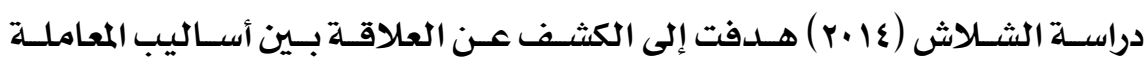

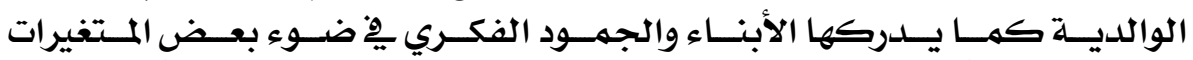

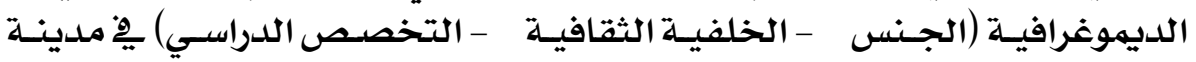

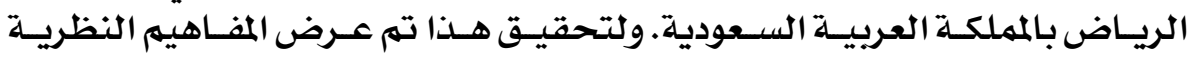

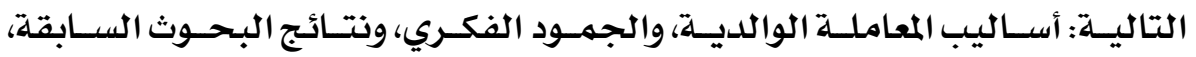




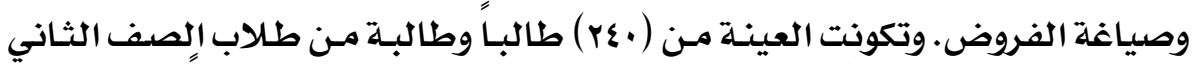

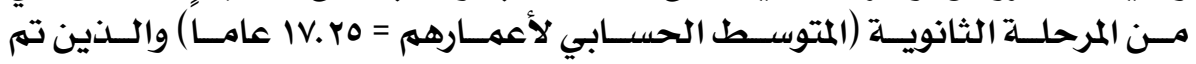

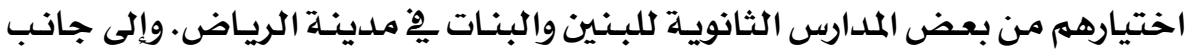

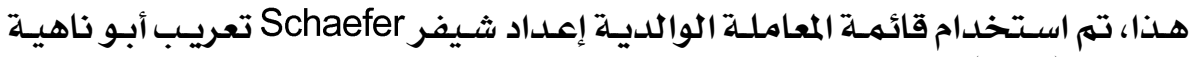

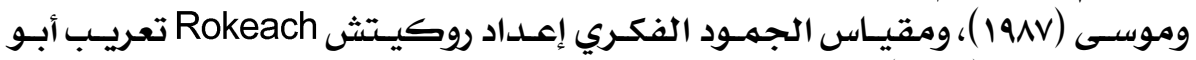

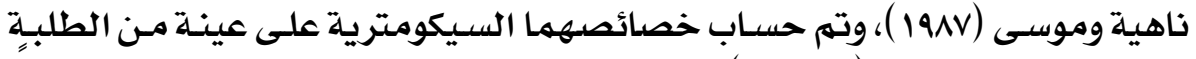

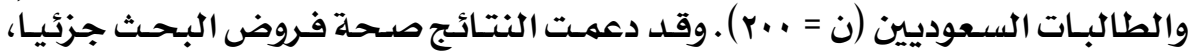

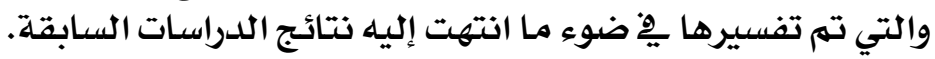

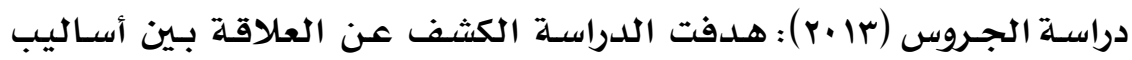

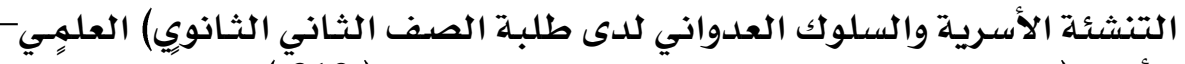
الأدبي (يْ محافظة حمص، وتكونت عينـة الدراسلة من (

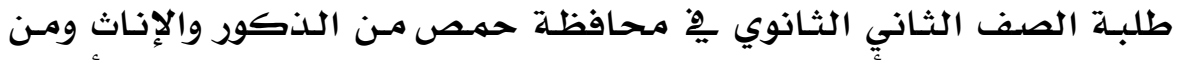

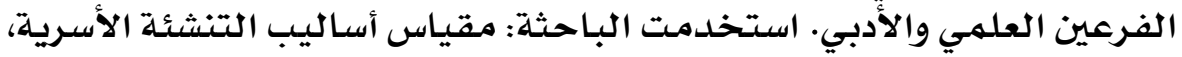

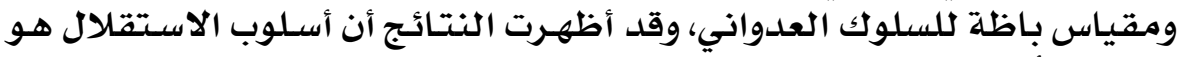

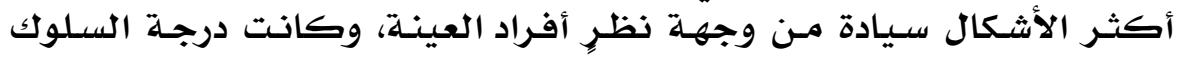

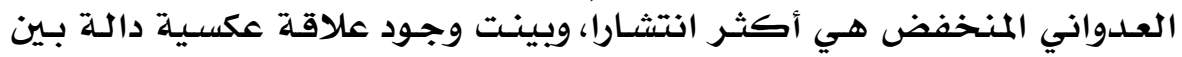

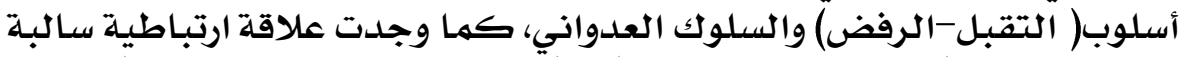

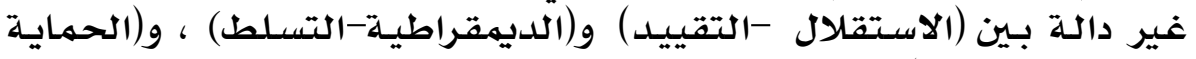

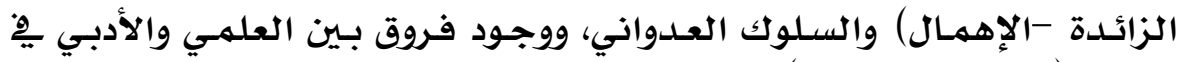

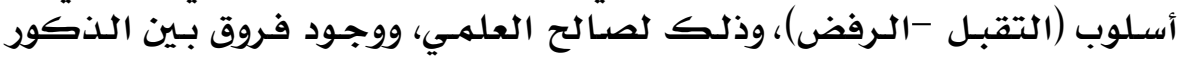

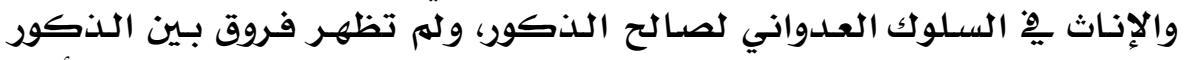

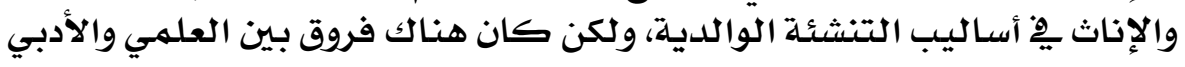

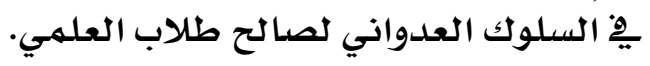

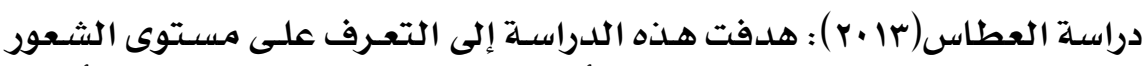

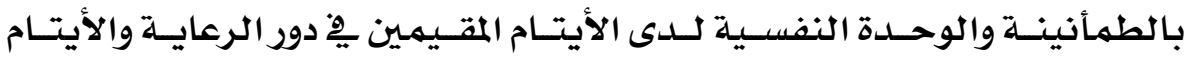

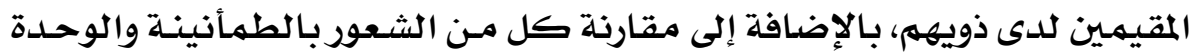

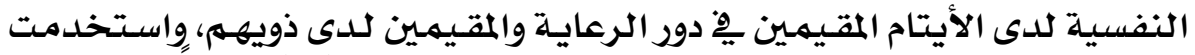

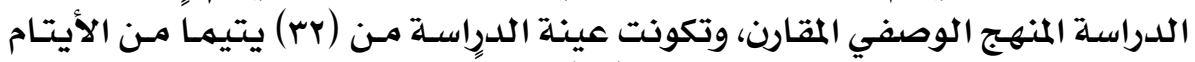

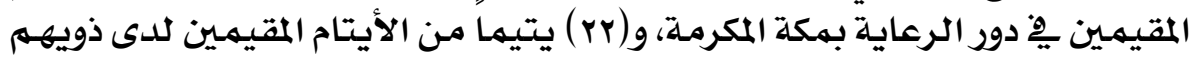

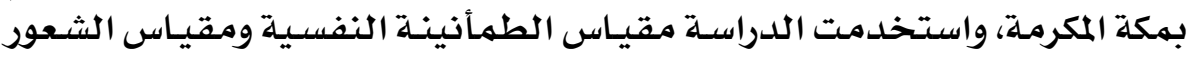

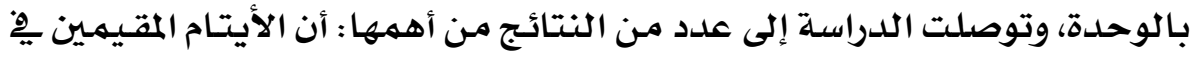

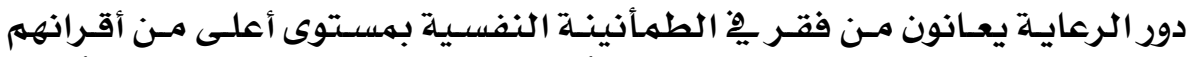

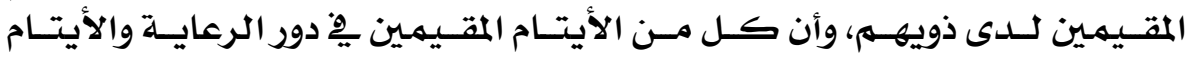

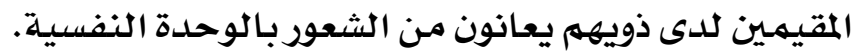




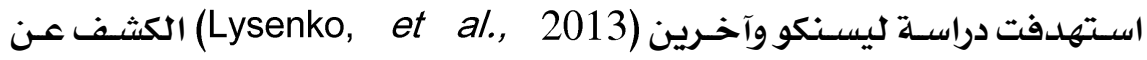

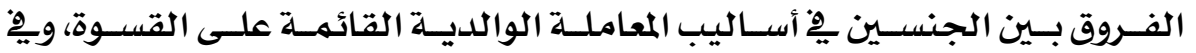

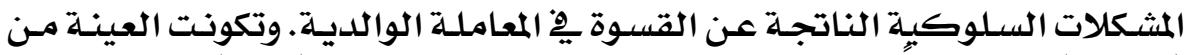

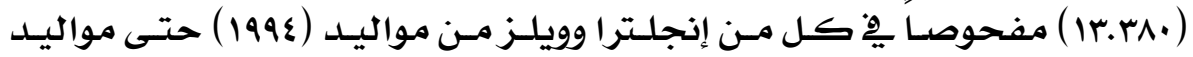

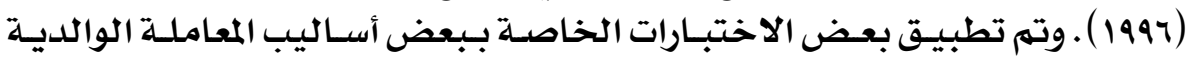

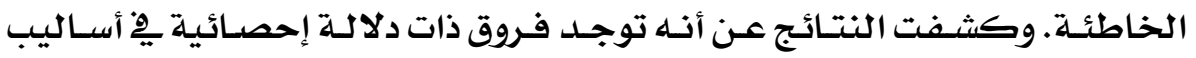

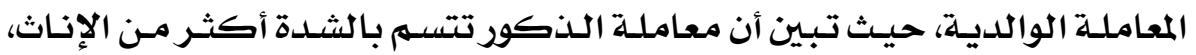
وكذلك يِ المثكلات السلوكية.

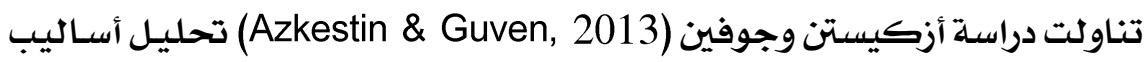

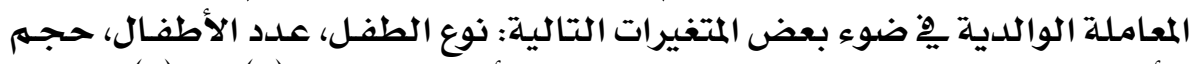

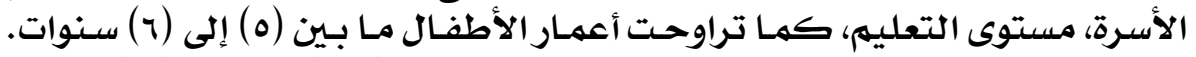

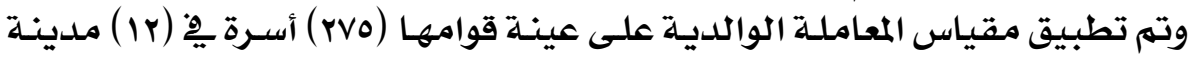

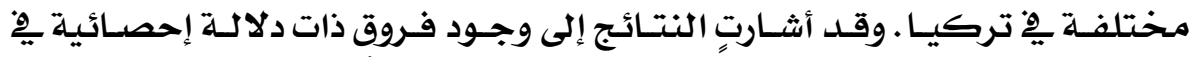

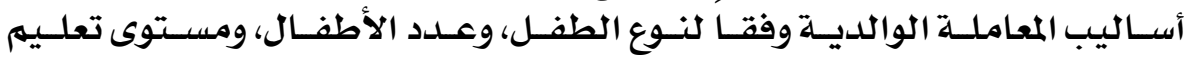
الوالدين.

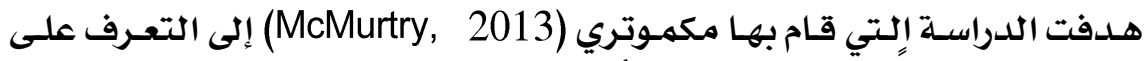

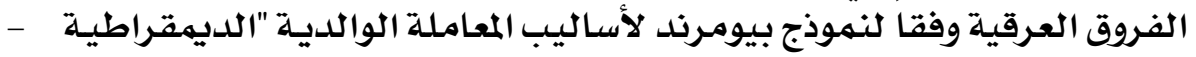

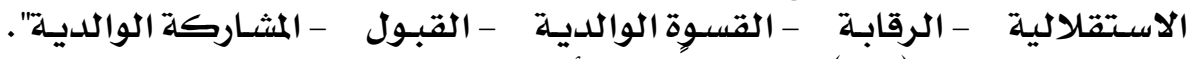

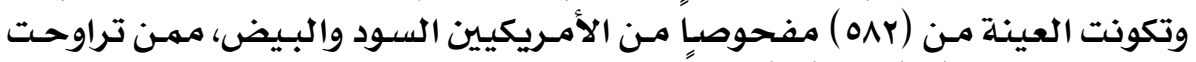

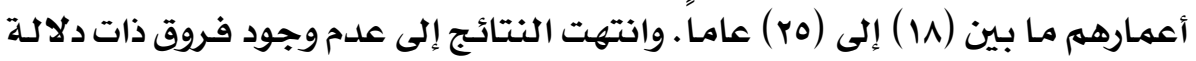

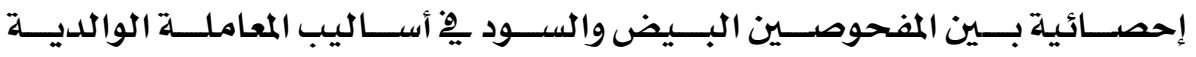

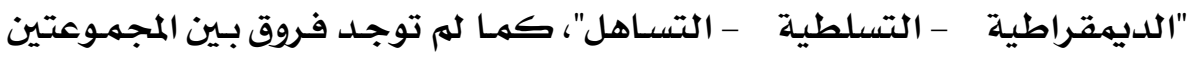

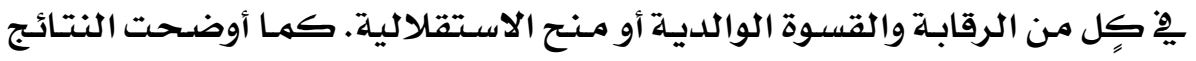

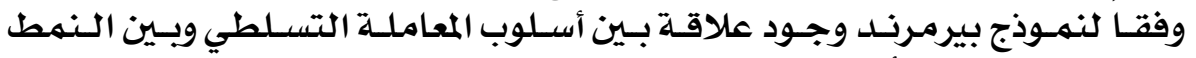

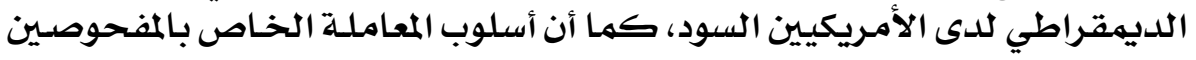
السود كان أكثر صرامـة مقارنة بالمفحوصين الادين البيض.

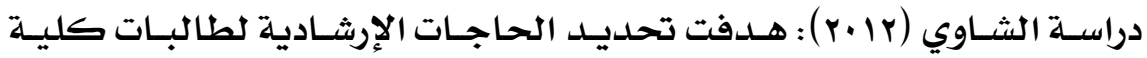

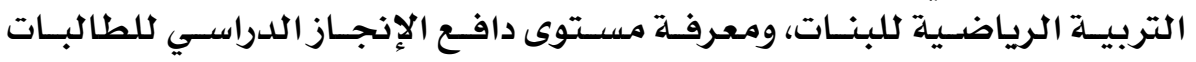

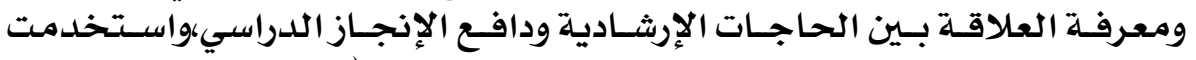

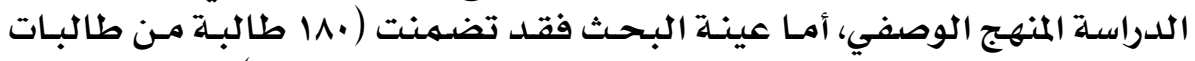

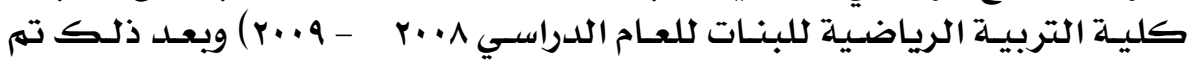

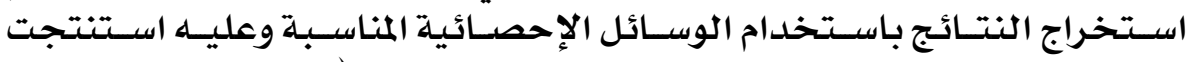

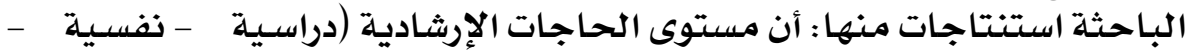




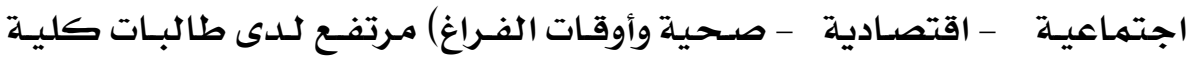

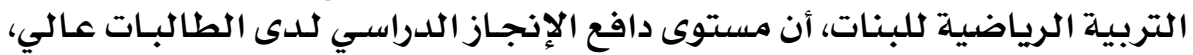

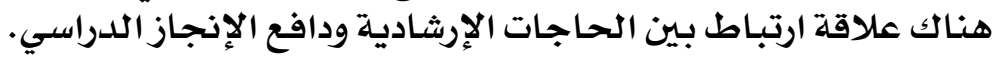

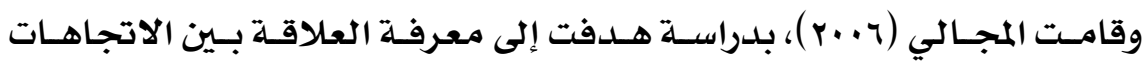

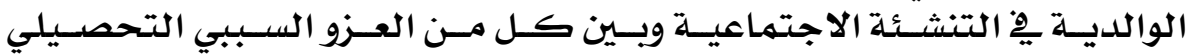

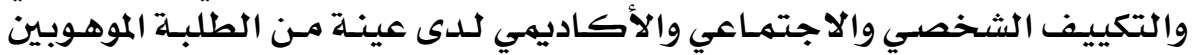

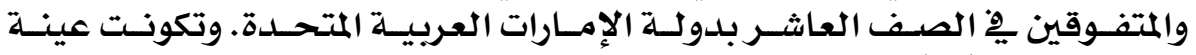

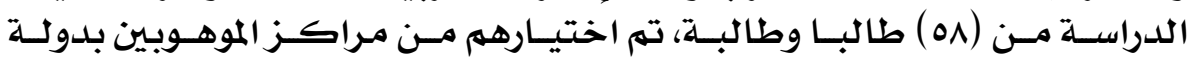

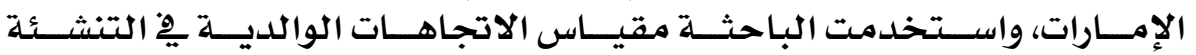

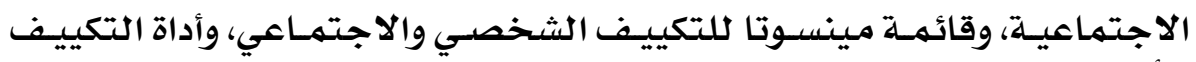

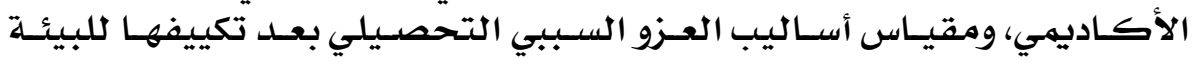

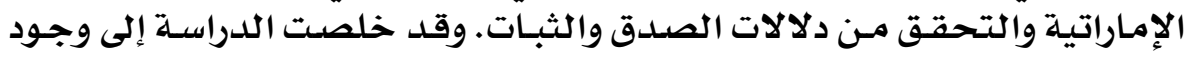

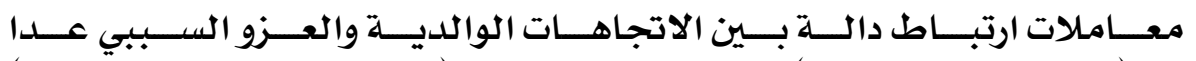

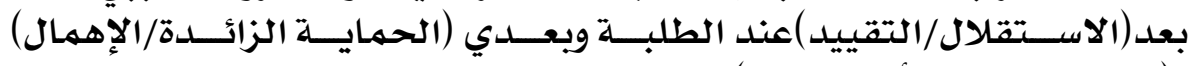

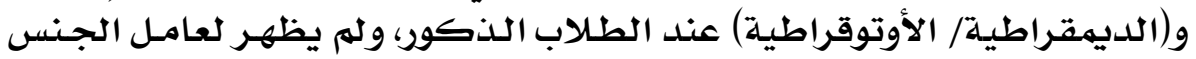

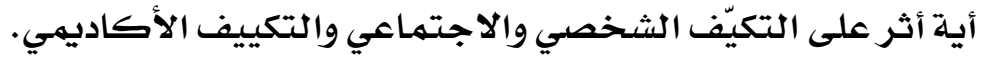

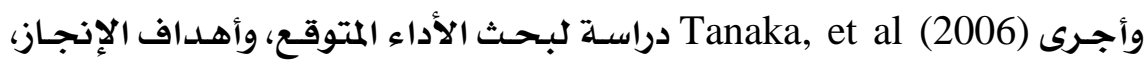

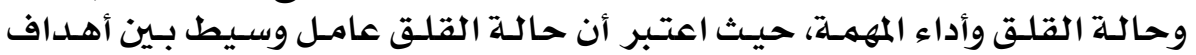

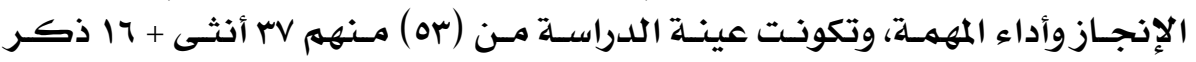

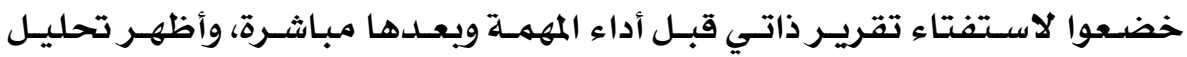

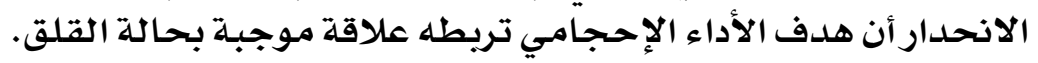

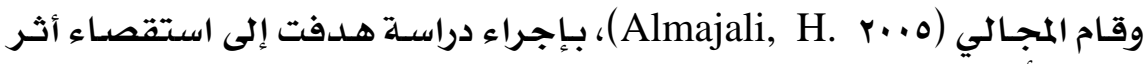

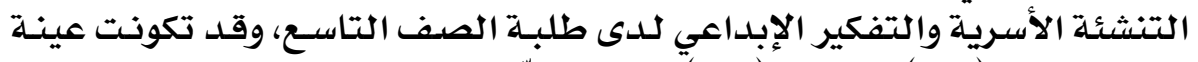

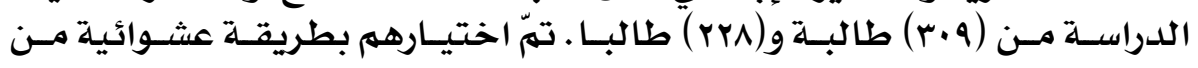

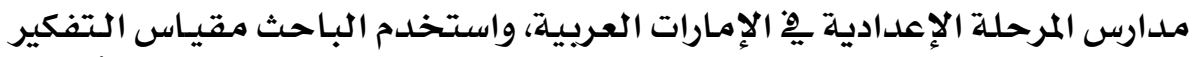

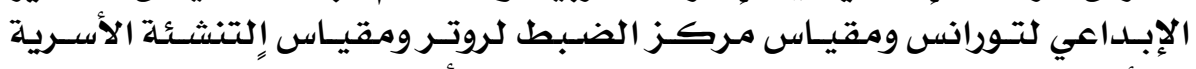

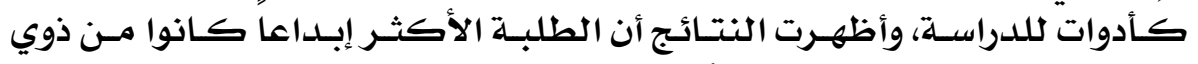

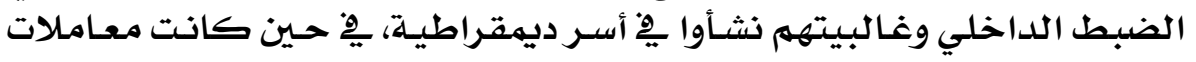

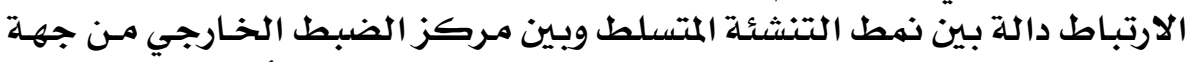

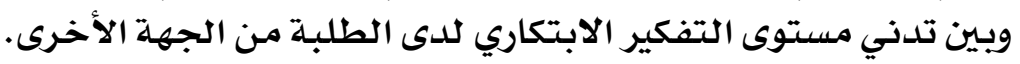

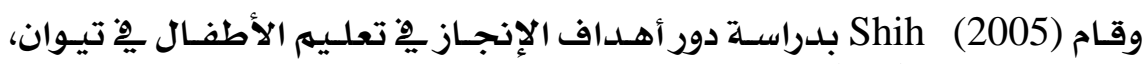

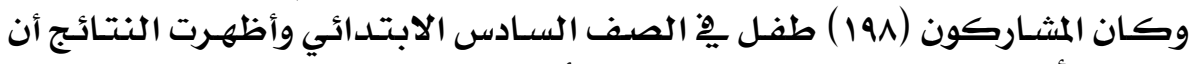

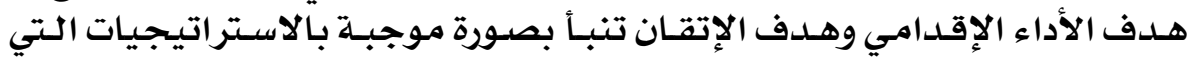

\section{$\varepsilon+1$}




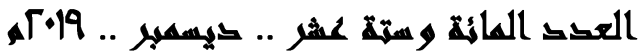

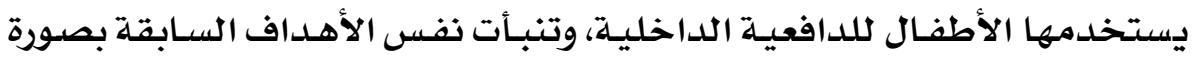

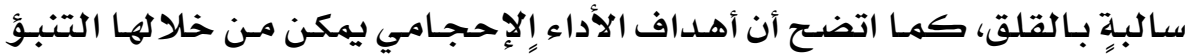

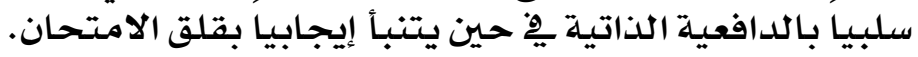

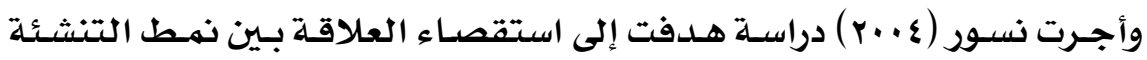

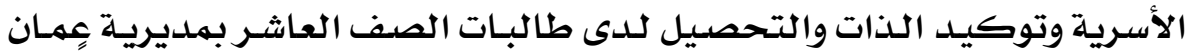

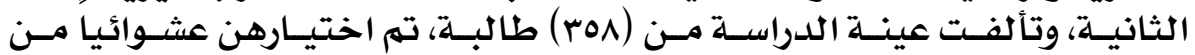

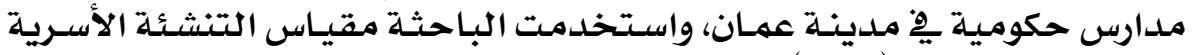

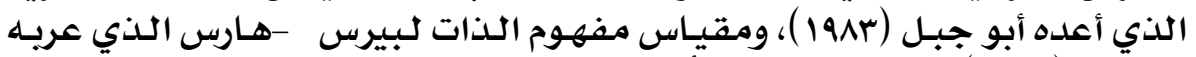

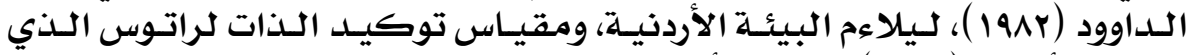

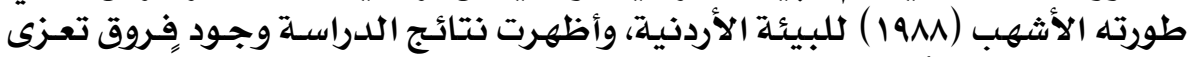

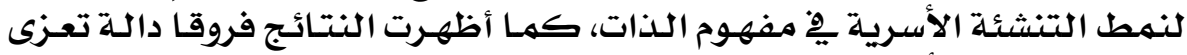

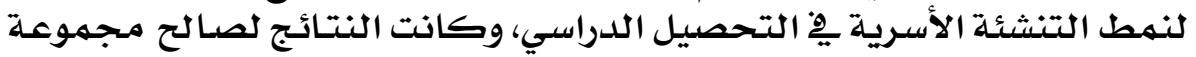
النهط الديمقراطي.

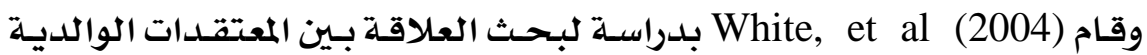

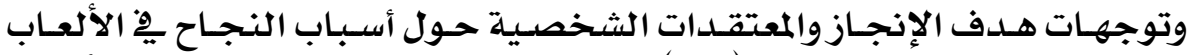

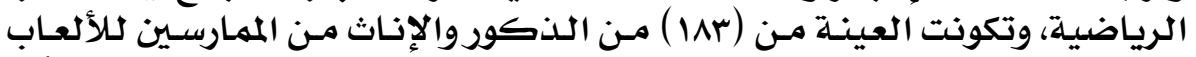

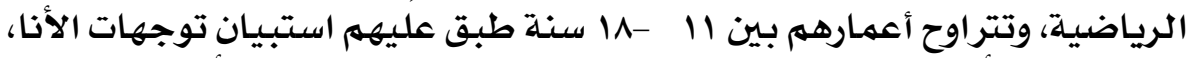

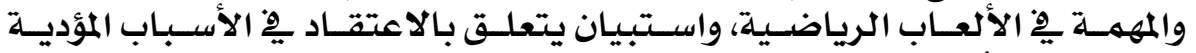

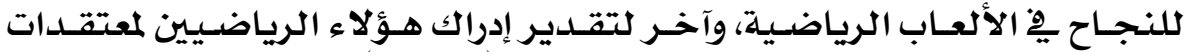

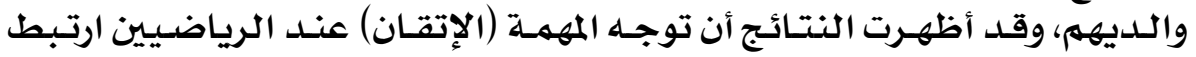

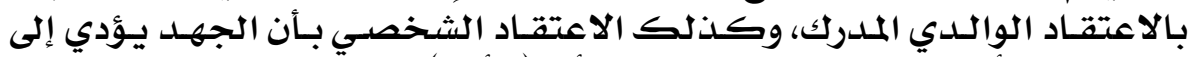

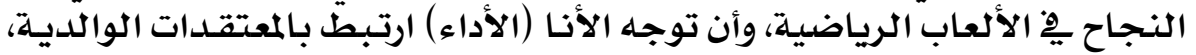

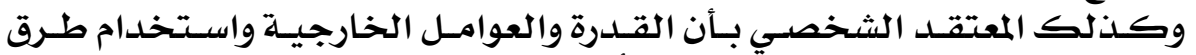

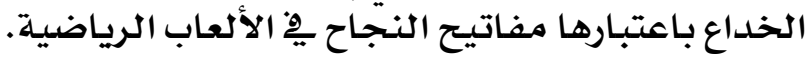

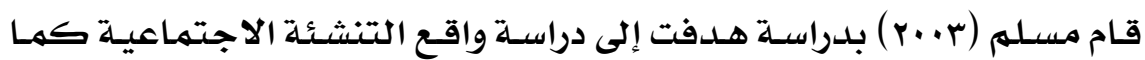

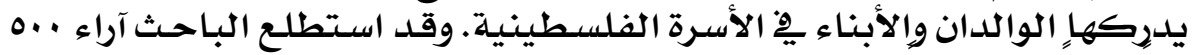

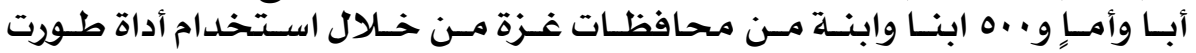

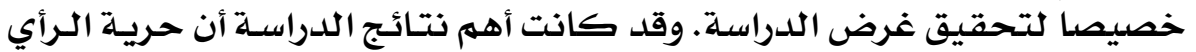

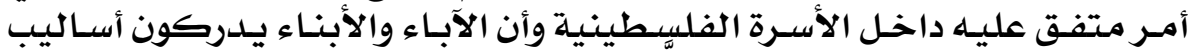

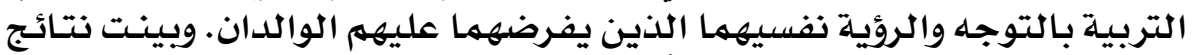

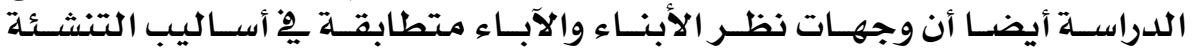

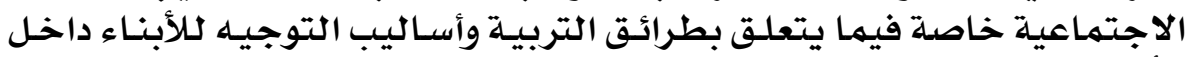
الأسـرة.

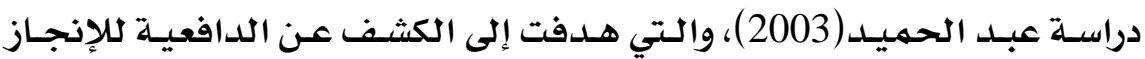

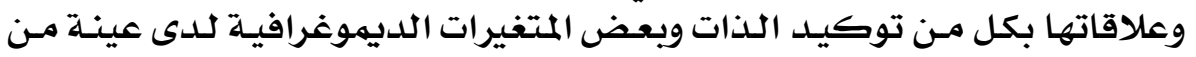

\section{$\varepsilon, Y$}




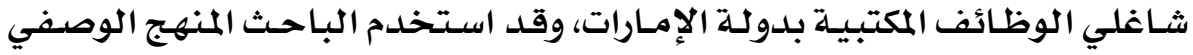

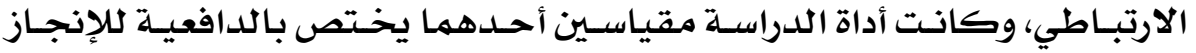

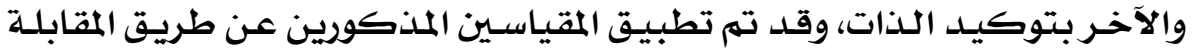

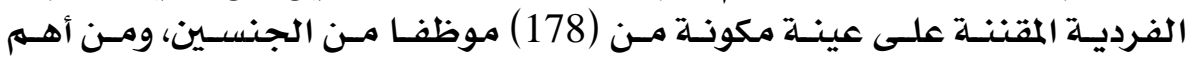

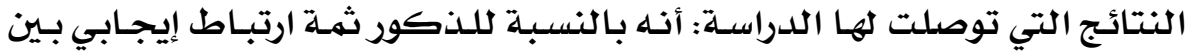

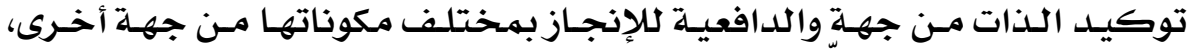

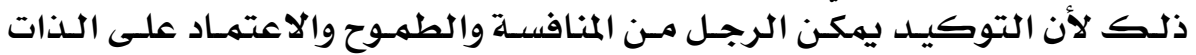

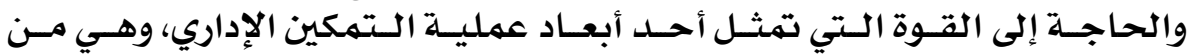

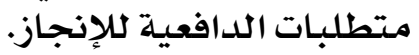

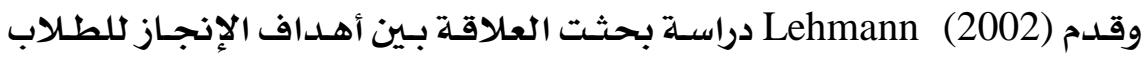

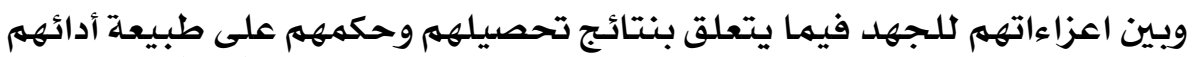

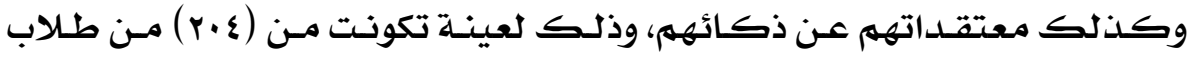

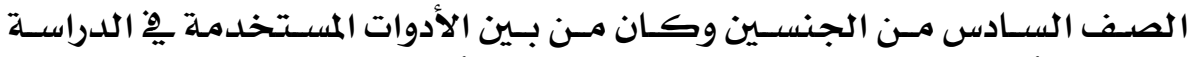

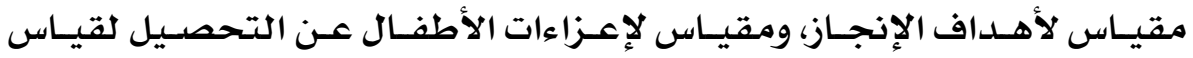

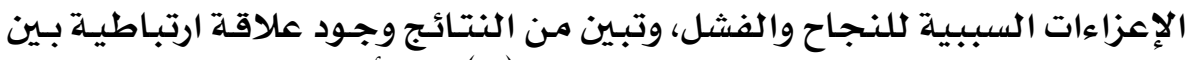

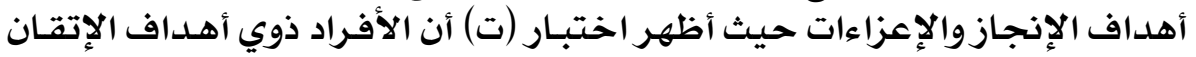

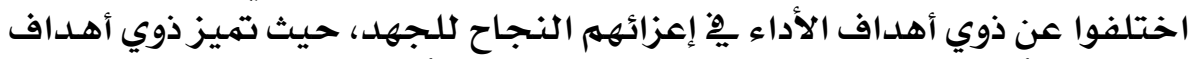

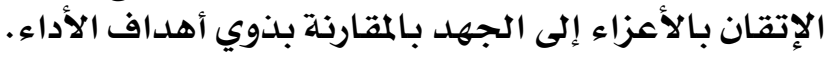

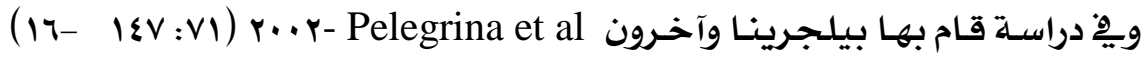

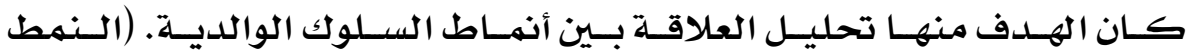

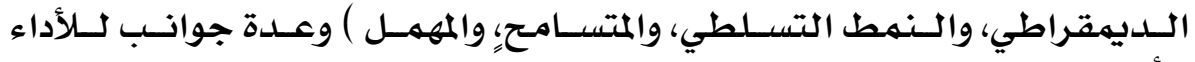

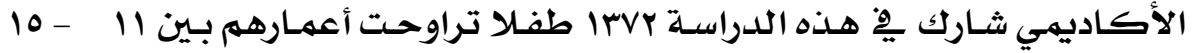

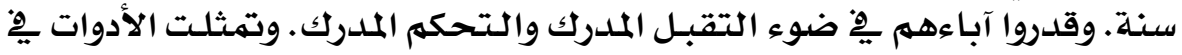

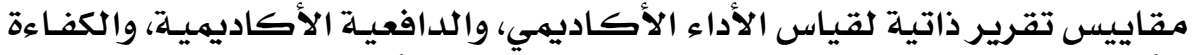

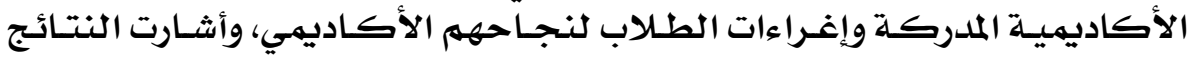

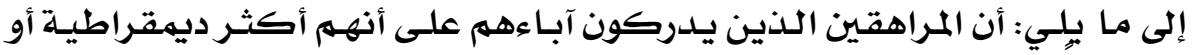

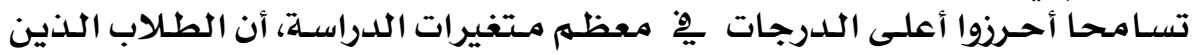

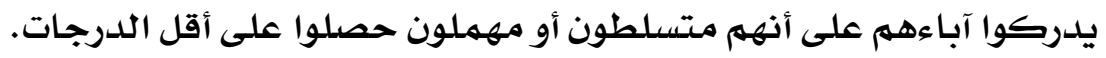

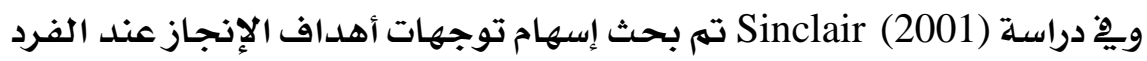

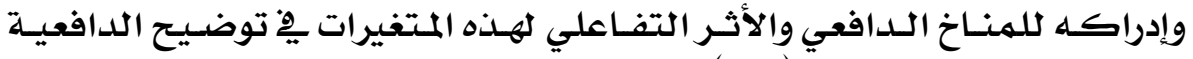

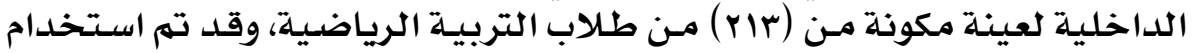

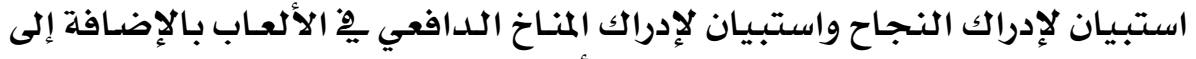

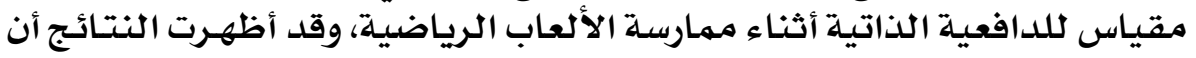




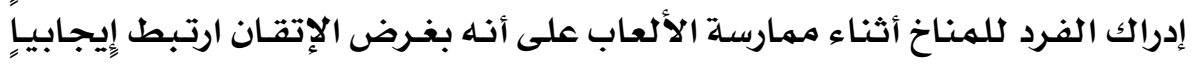

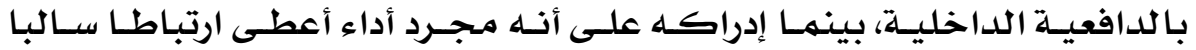

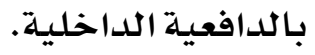

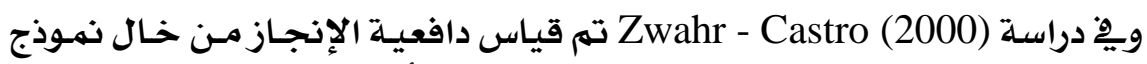

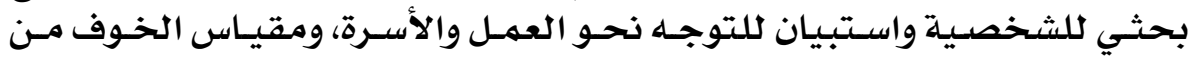

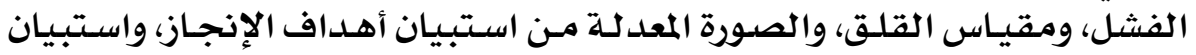

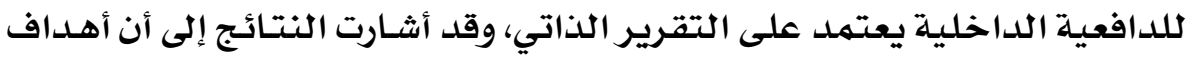

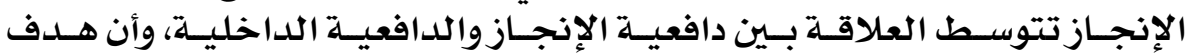

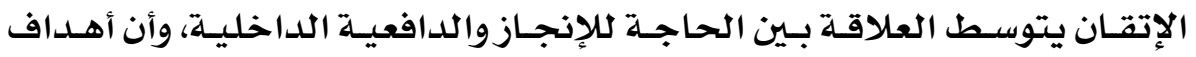

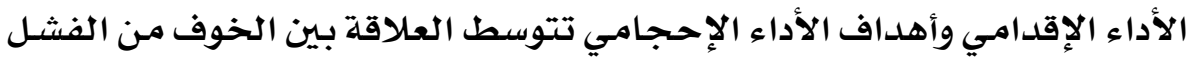

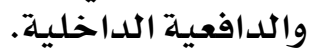

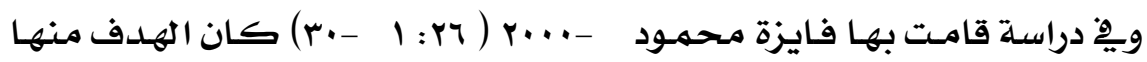

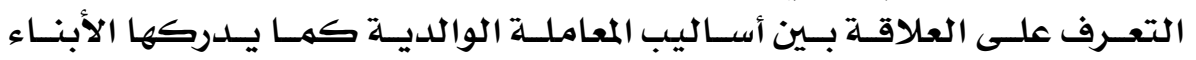

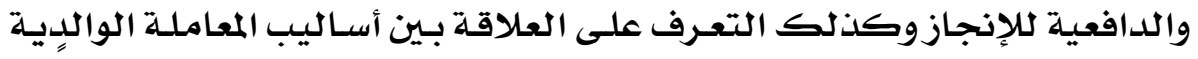

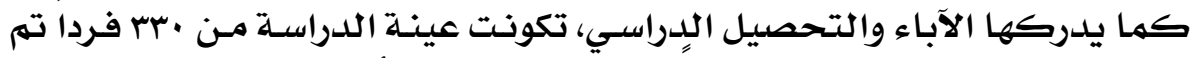

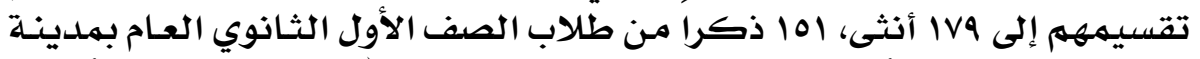

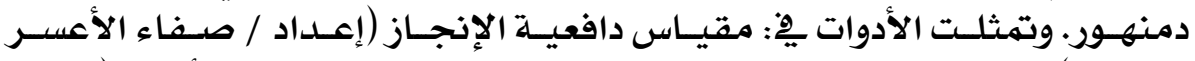

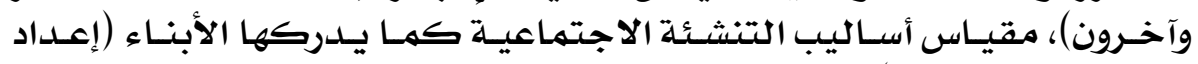

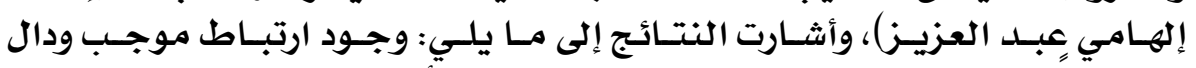

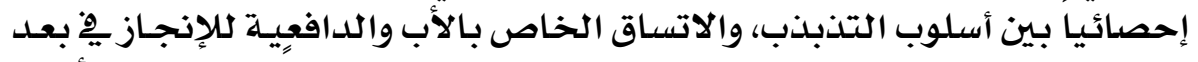

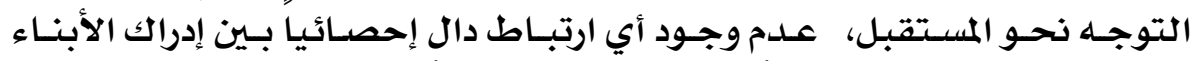

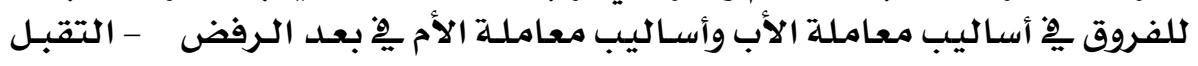

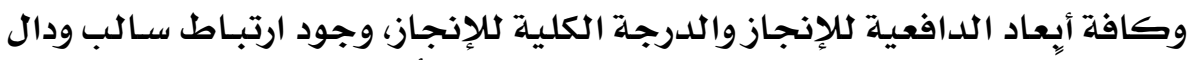

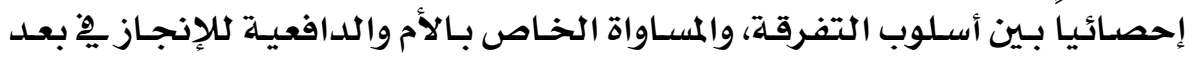

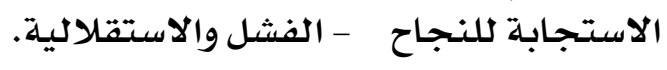
التعايق على الدراسات السابقة:

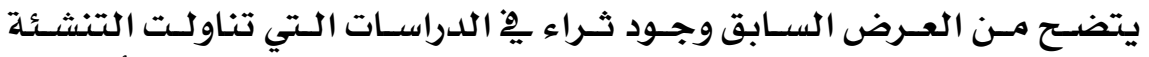

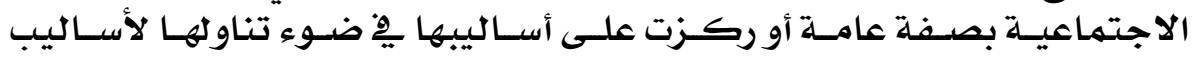

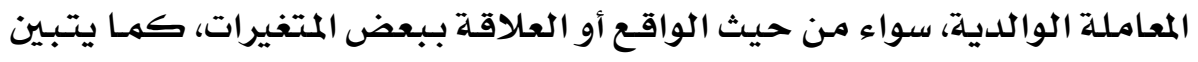

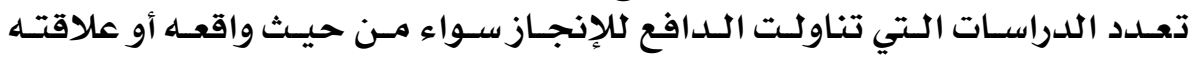

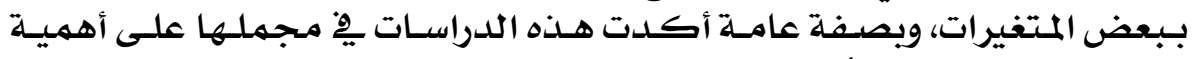

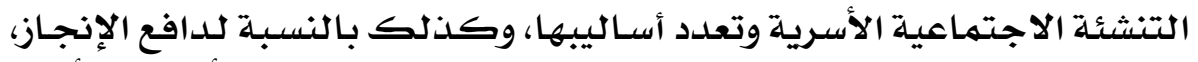

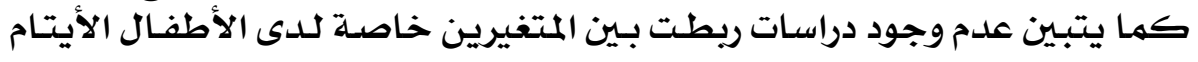

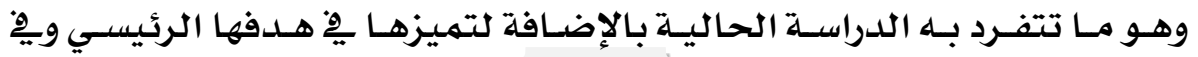

\section{$\varepsilon \cdot \varepsilon$}




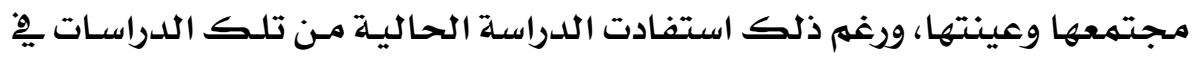

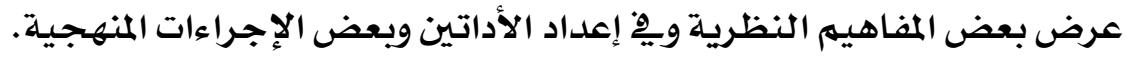

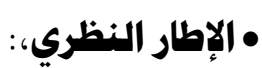
• المحور الأول: الإطار المفاهيسي للتنشئئة الاجتهاعية الأسرية. • مفهوم التنشئة الاجتهماعية:

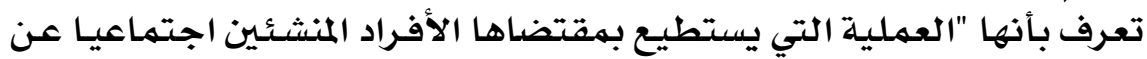

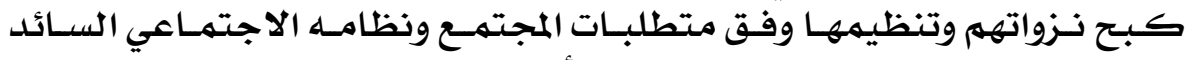

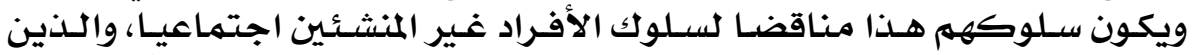

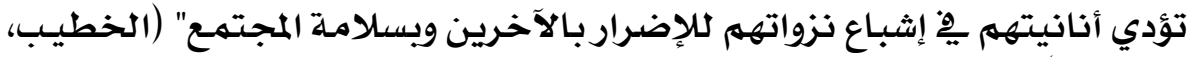

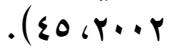

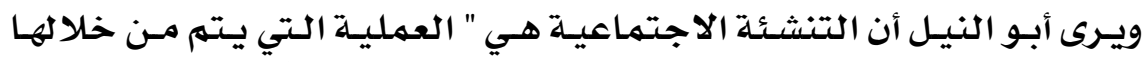

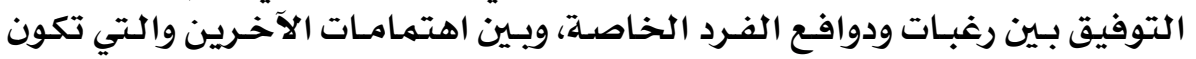

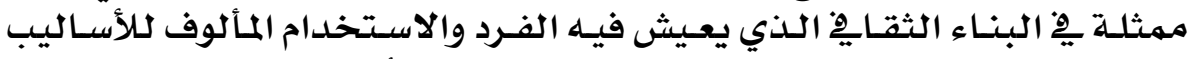

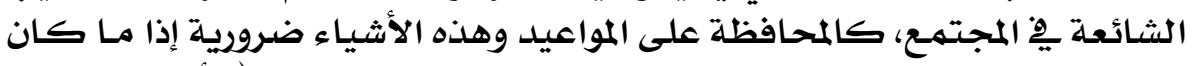

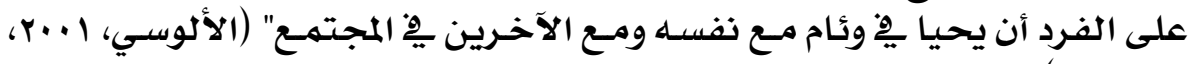
. ( VA r r...r

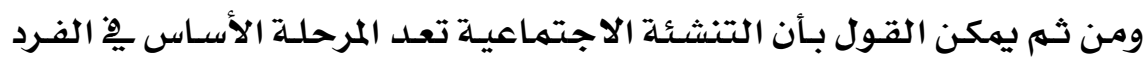

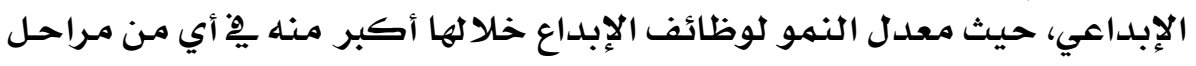

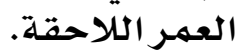
• أهداف التنشئية الاجتهماعية:

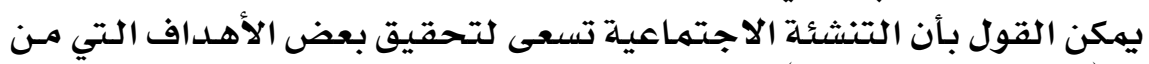

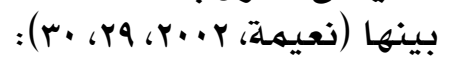

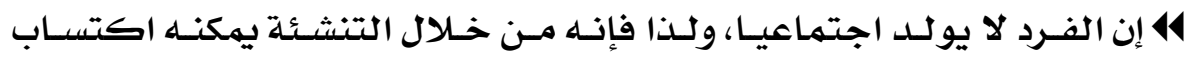

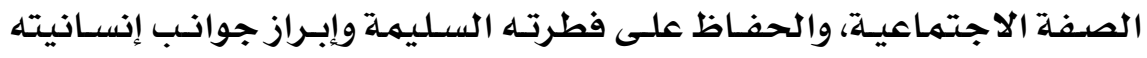

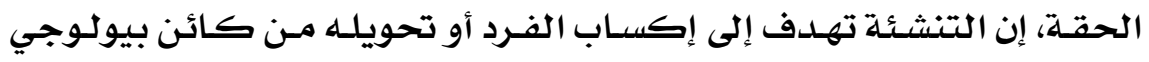

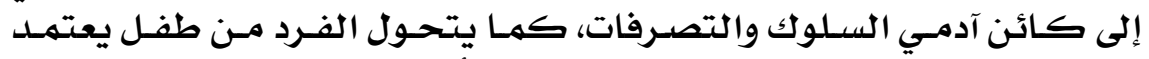

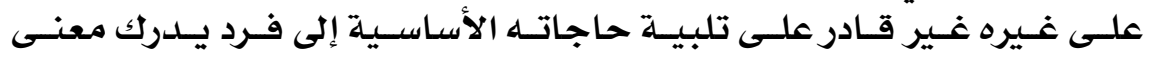

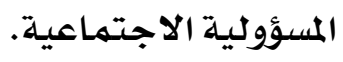

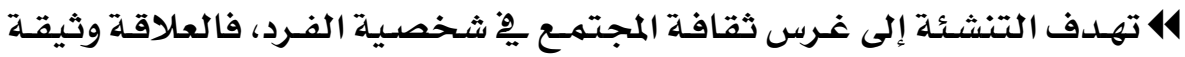

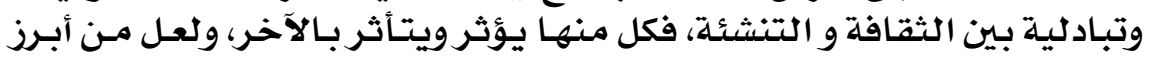

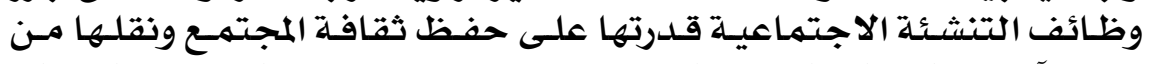

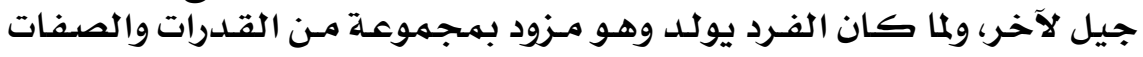

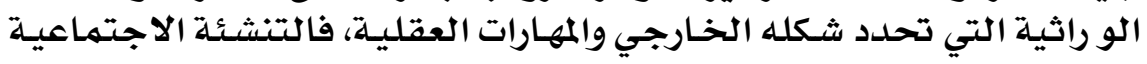

\section{$\varepsilon \cdot \odot$}




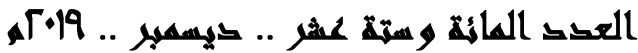

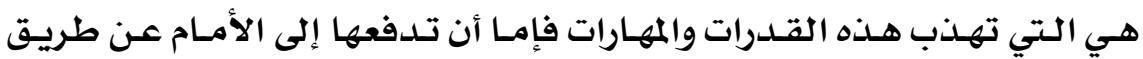

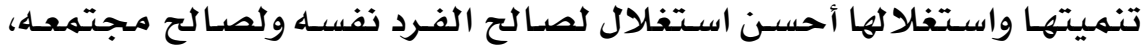

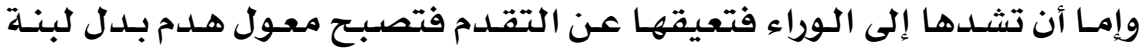

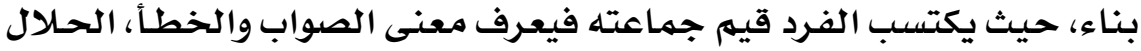

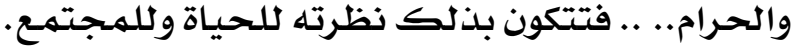

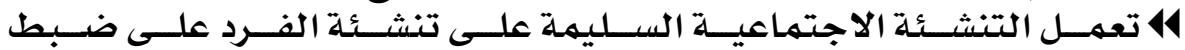

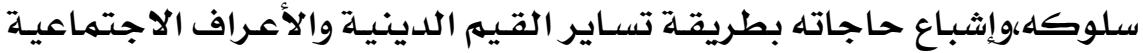

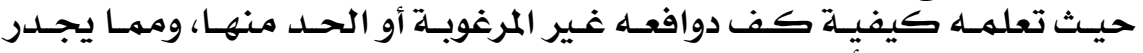

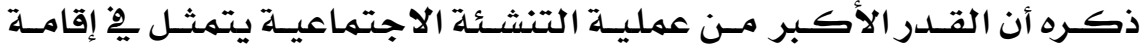

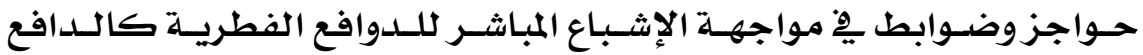

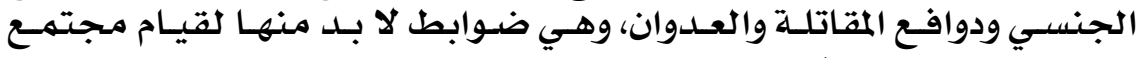

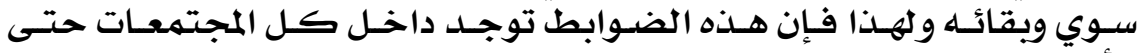
الأكثر بدائية وائه

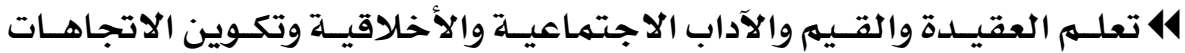

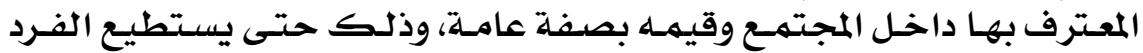

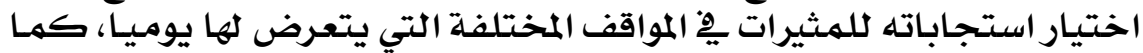

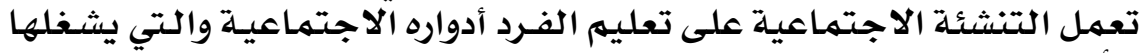

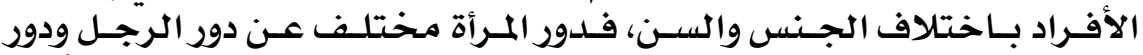

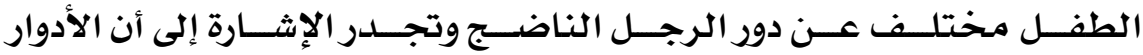

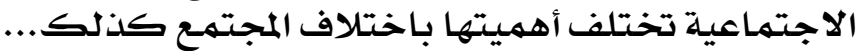

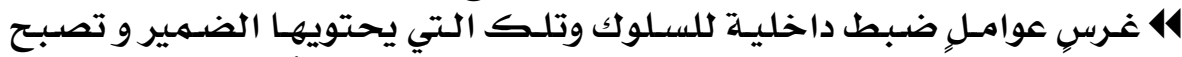

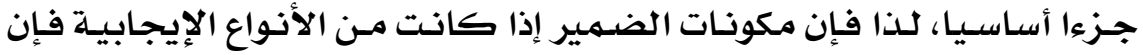

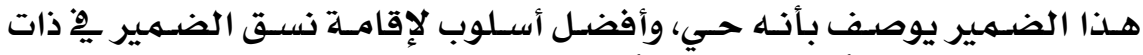

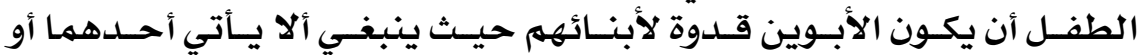

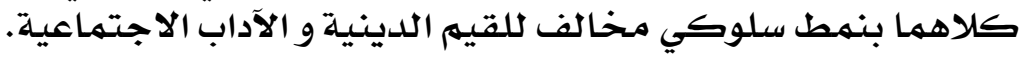

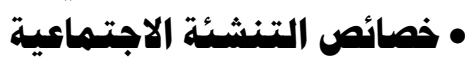

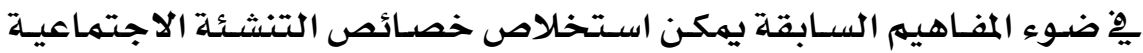

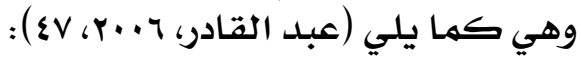

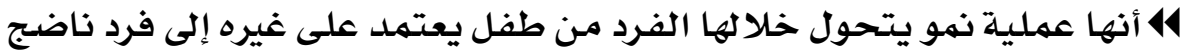

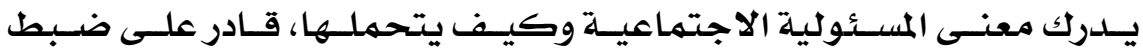

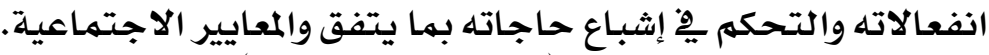

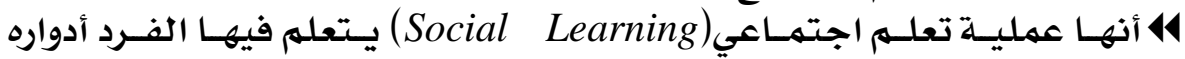

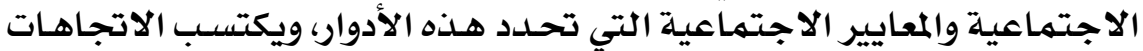

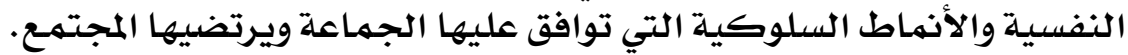

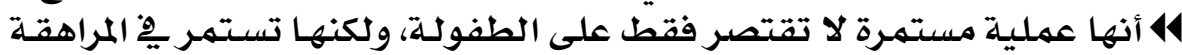

$$
\text { والرشد وحتى الشيخوخة }
$$




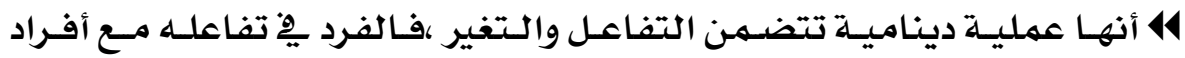

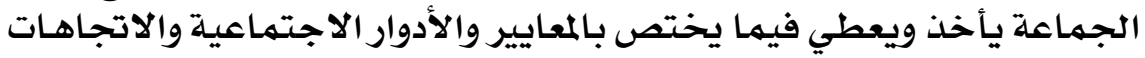
النفسية. 44 أنها عملية معقدة متشعبـة تستهدف مهام مهام كبيرة، وتستخلدم أسـاليب ووسـائل متعددة لتحقيق ما تهدف إليه.

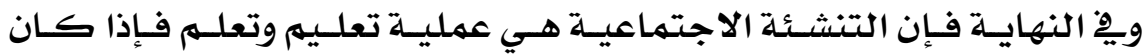

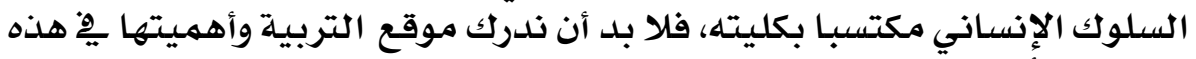

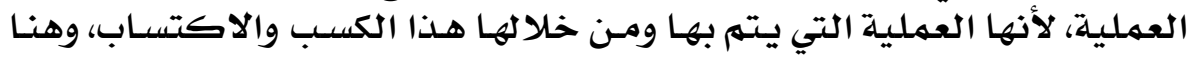

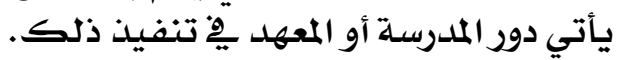

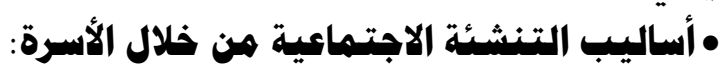

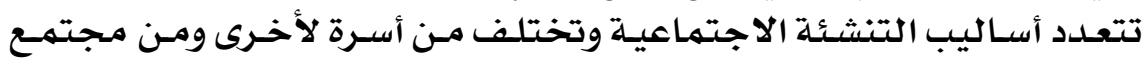

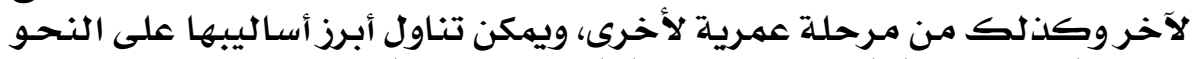

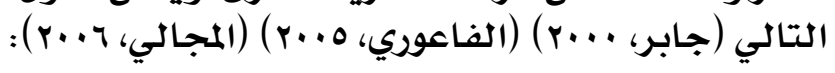

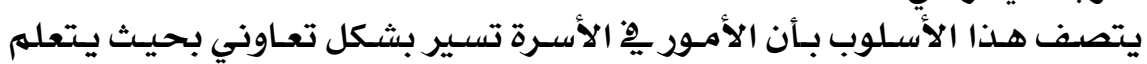

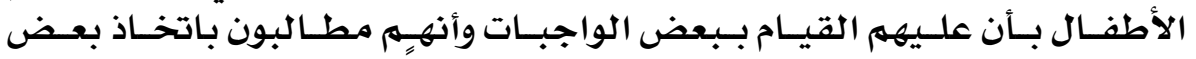

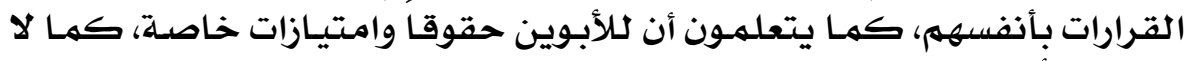

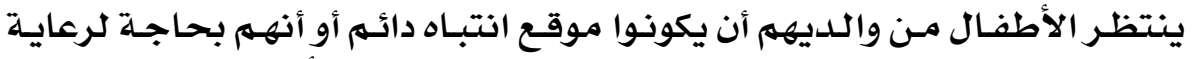

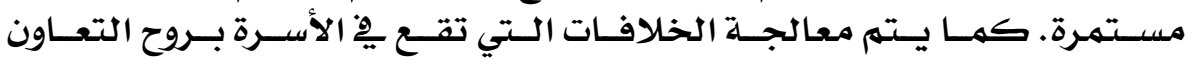

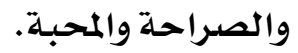

$$
\begin{aligned}
& \text { أمًا عن الآثار التي يخلفها هذا هذا الأسلوب على الألى الفرد فهي: }
\end{aligned}
$$

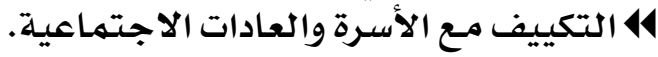

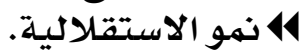

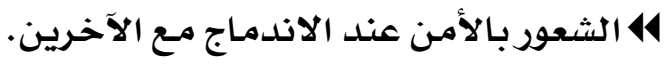

$$
\begin{aligned}
& \text { • الأسلوب التسلطي: }
\end{aligned}
$$

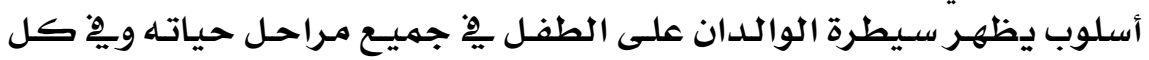

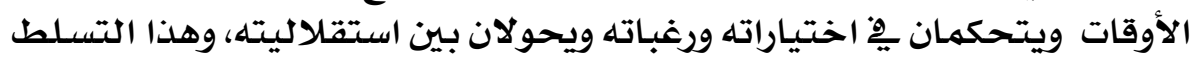

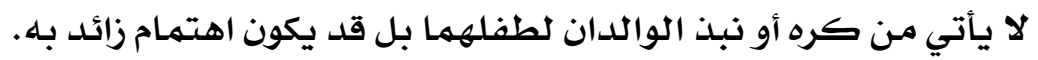

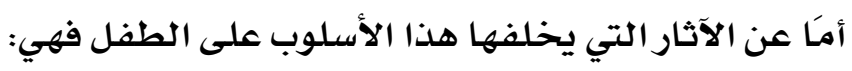

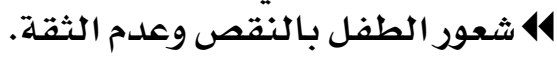

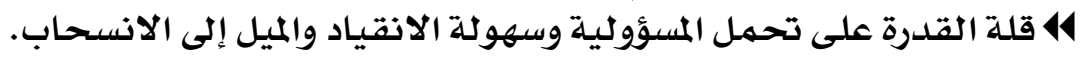

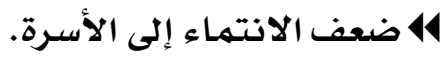

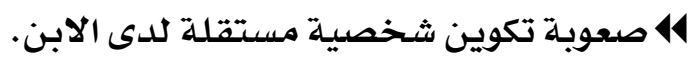

\section{$\varepsilon \cdot V$}




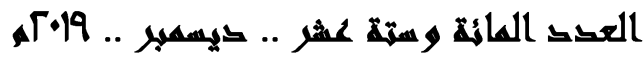

$$
\text { • } 41 \text { الخدم الرفبلة الشديد من القيام بالوالدين. }
$$

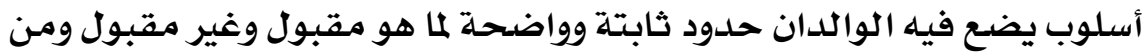

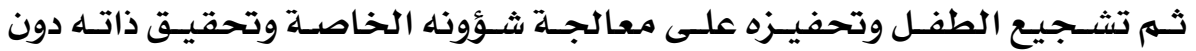
الاعتماد على الآخرين.

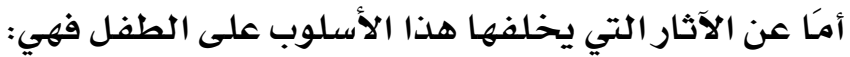

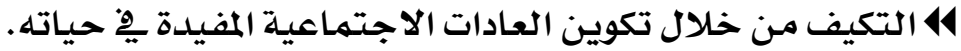
14 التحمل المسؤولية.

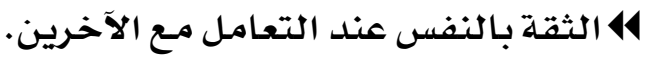

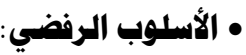

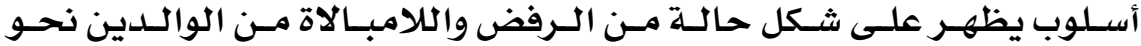

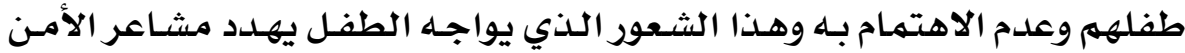

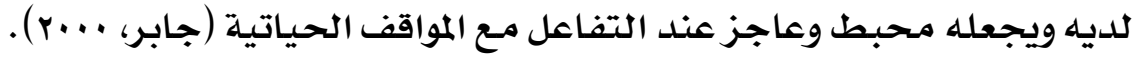
أمَا عن الآثار التي يخلفها هذا الأسلوب على الطفل فئل فهي:

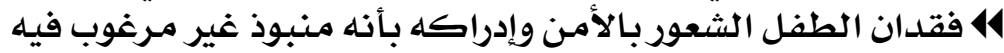

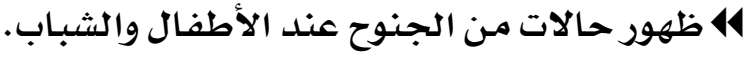

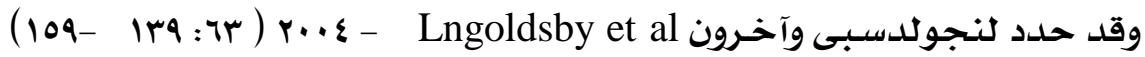

Positive induction

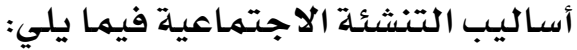
Monitoring

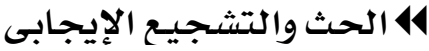
Autonomy 14 المراقبة والضبط

Punitiveness

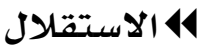

Permissiveness

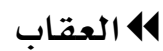

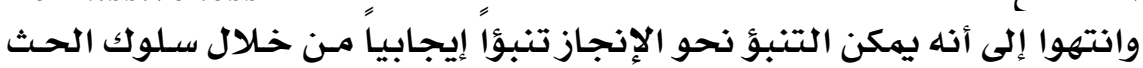

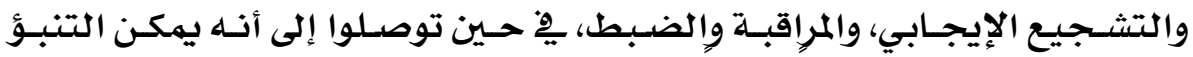

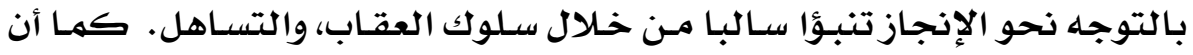

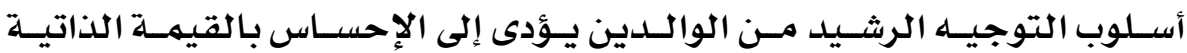

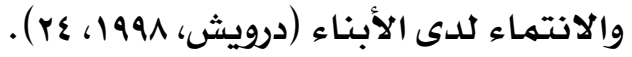

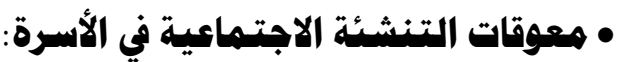

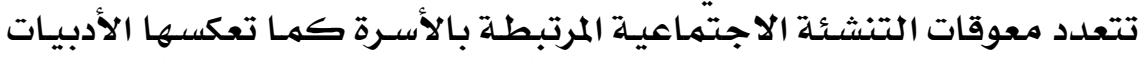

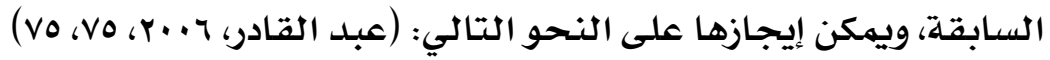




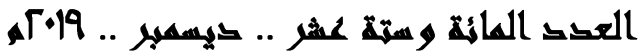

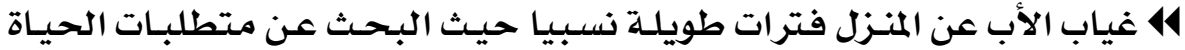

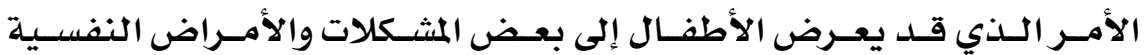
والاجتمهاعية.

41 الحرمان العاطفي للطفل بسبب خروج الأم للعمل، وترك الطفل لمربية ،أو مـع جيران المنزل.

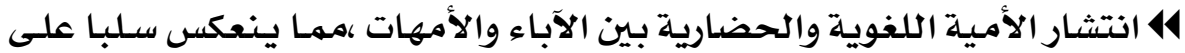

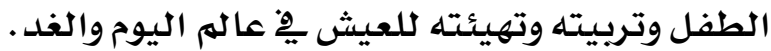

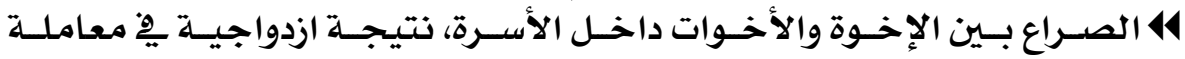

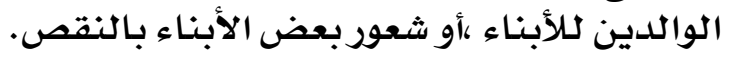

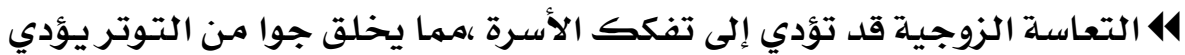

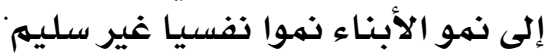

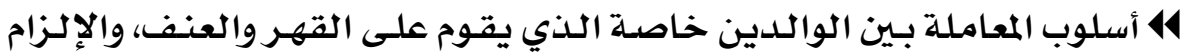

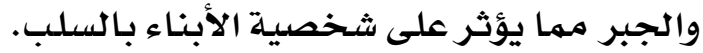

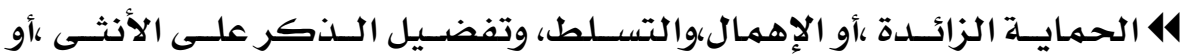

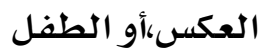

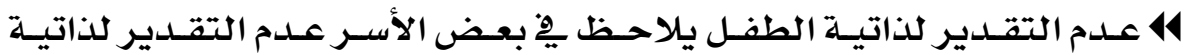

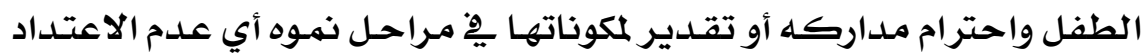

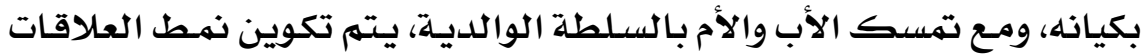

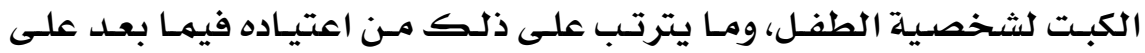
الإذعان بل والخوف مـن السلطة الطيّة

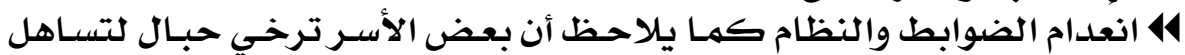

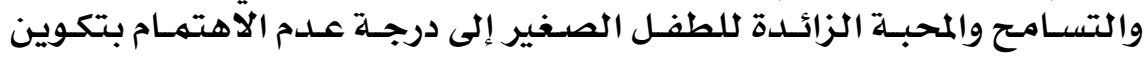

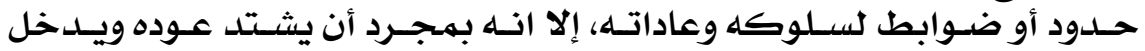

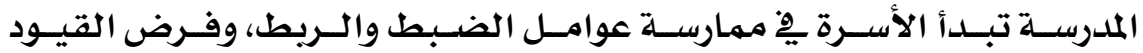

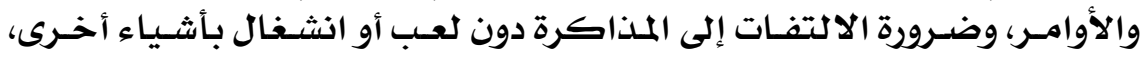

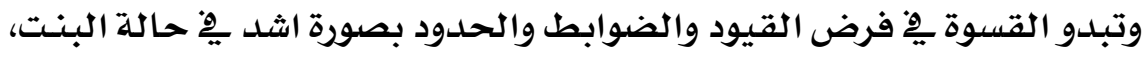

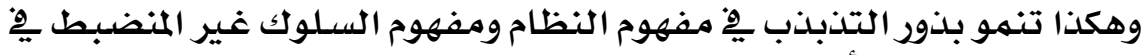

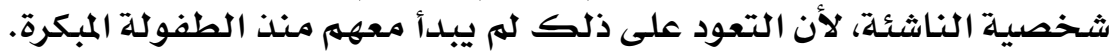

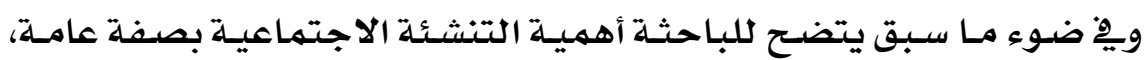

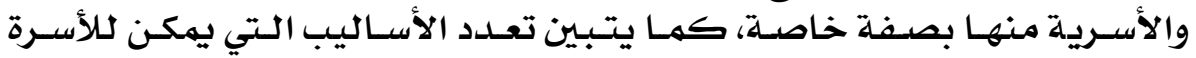

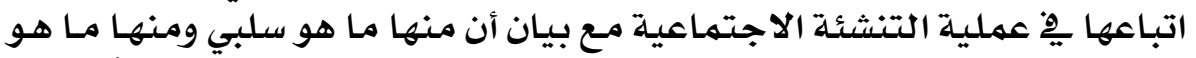

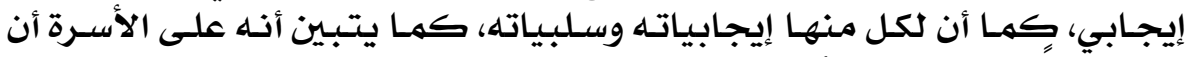

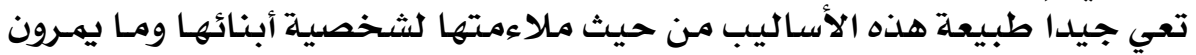

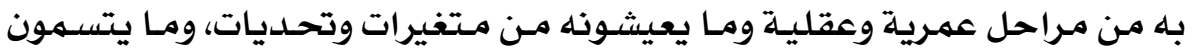




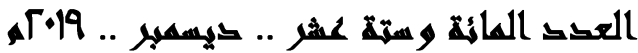

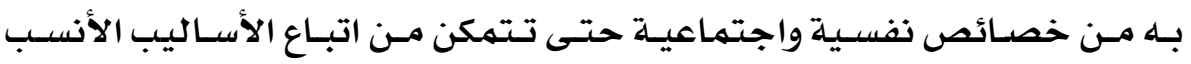
معهم فِ عملية التنشئة الاجتهماعية.

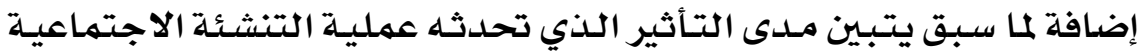

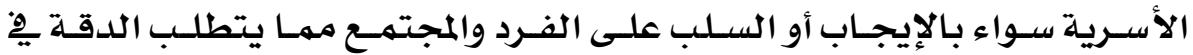

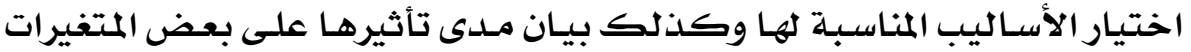

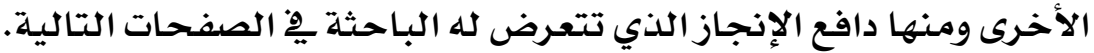

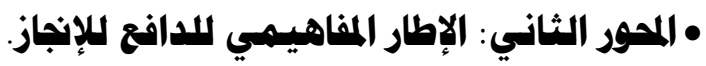

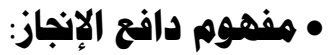
يشير (2000) Pintrich, إلى أن أهداف الإنجاز إنها تعبر عن سبب سعـي الفـرد لإنجاز مهمة ما. ألمان.

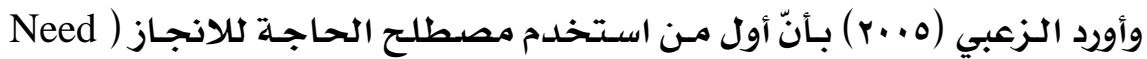

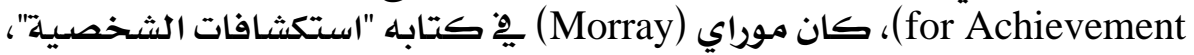

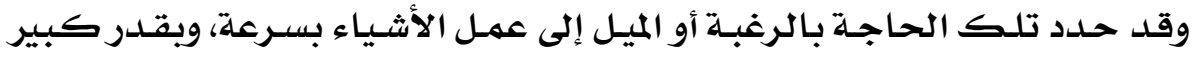

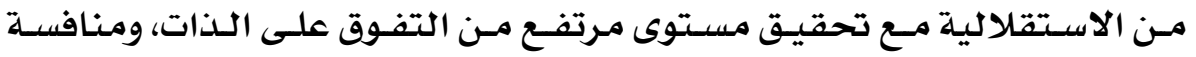
الآخرين والفوز عليهم.

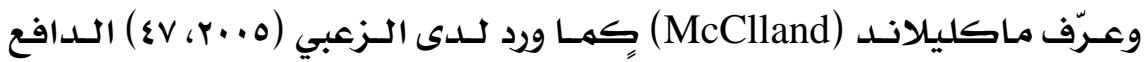

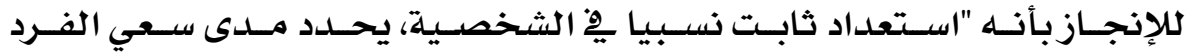

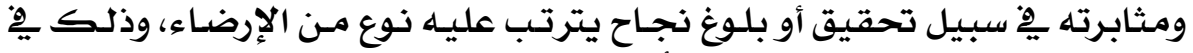

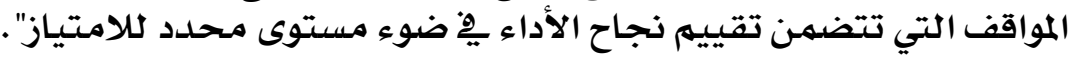

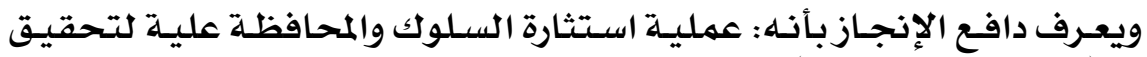

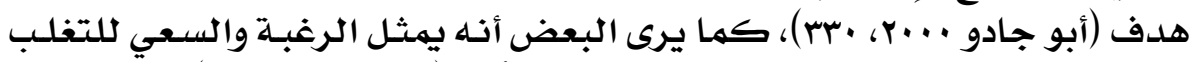

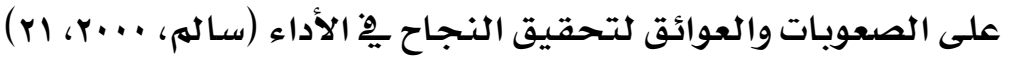

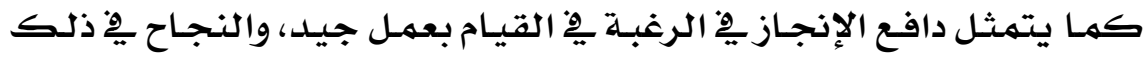

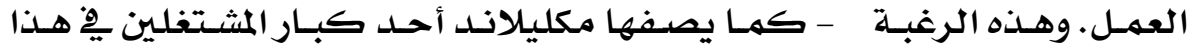

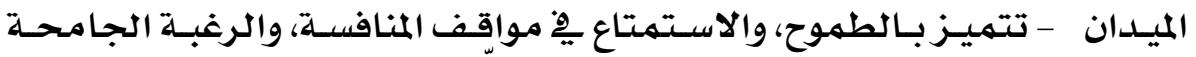

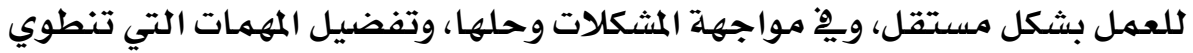

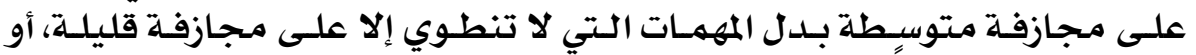

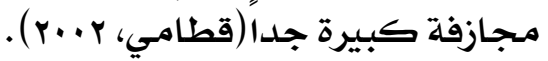

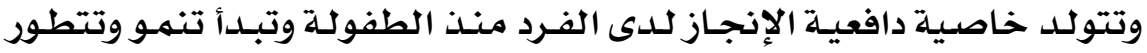

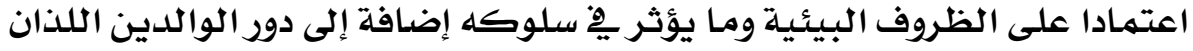

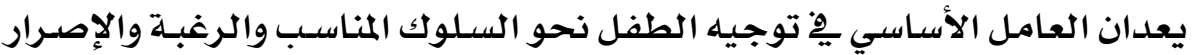

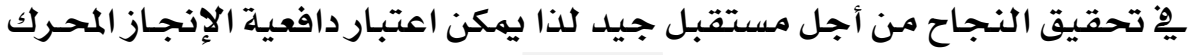

\section{\&1.}




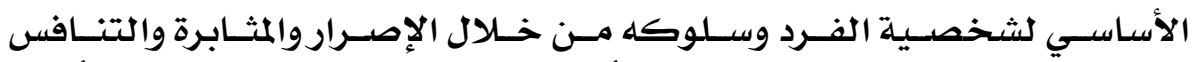

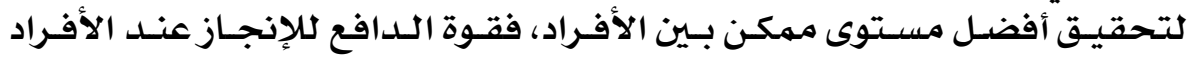

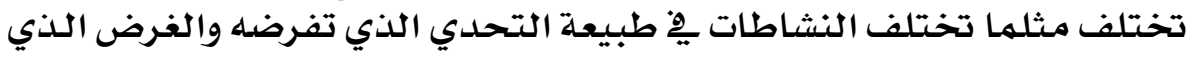

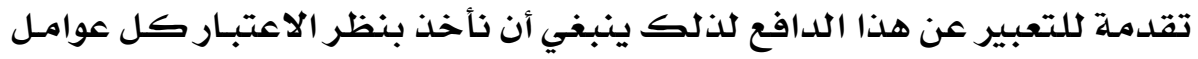

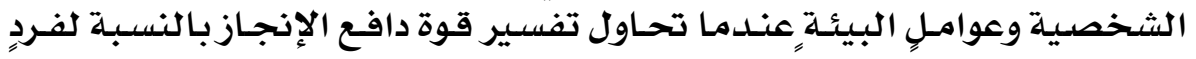

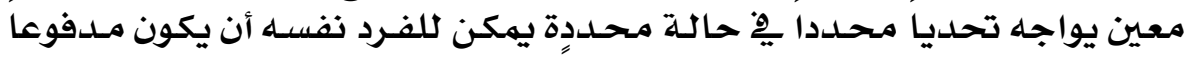

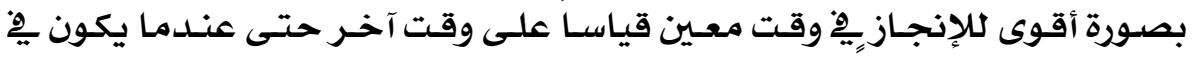

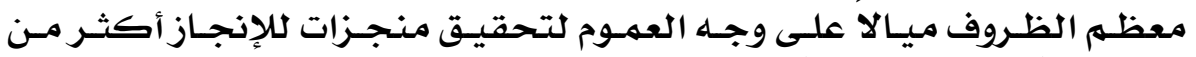

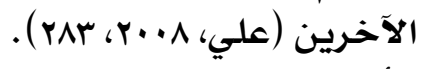

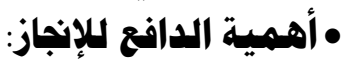

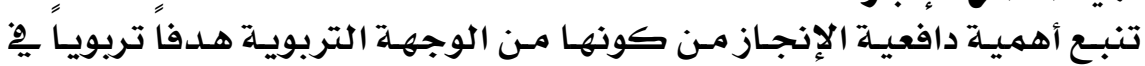

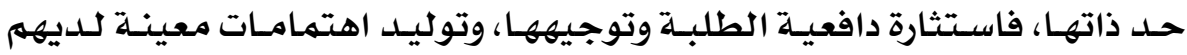

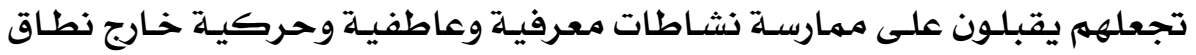

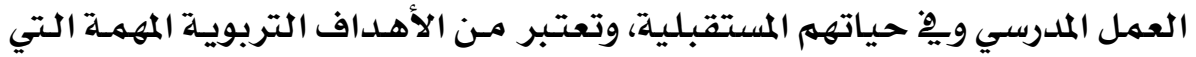

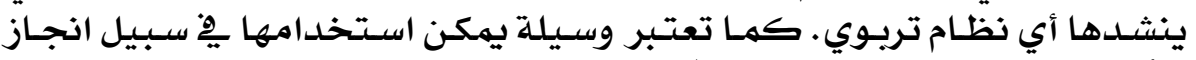

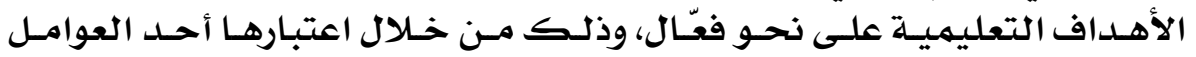

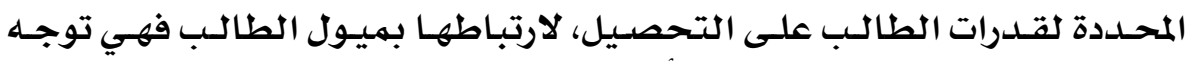

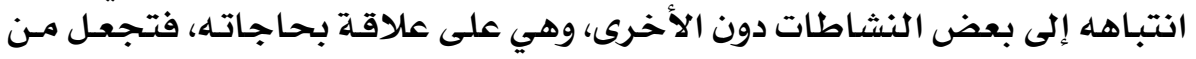

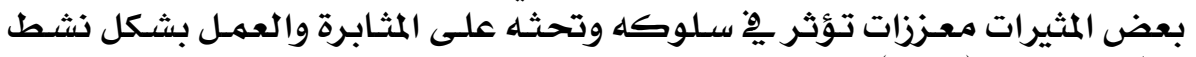

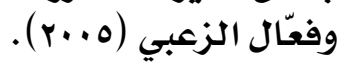

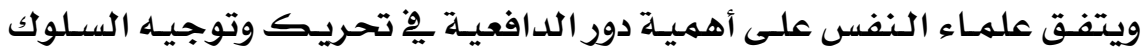

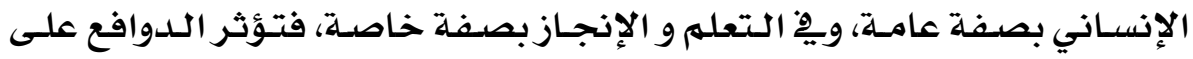

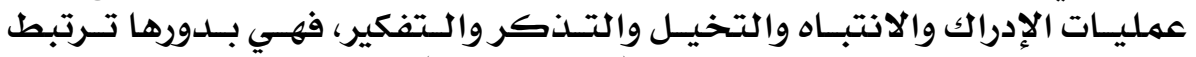

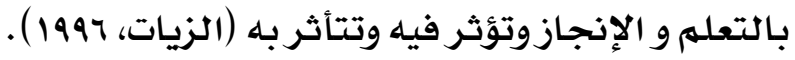

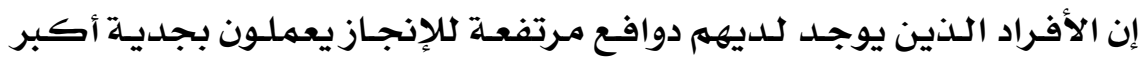

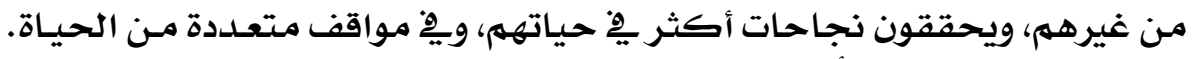

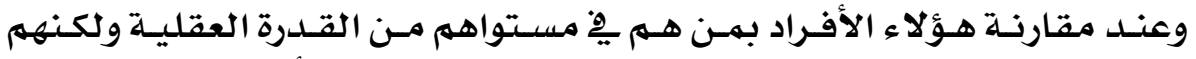

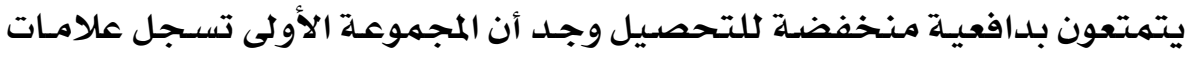

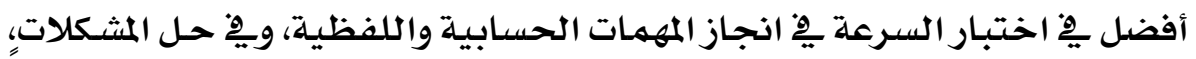

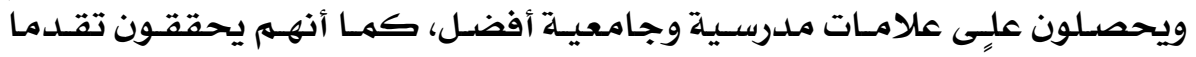

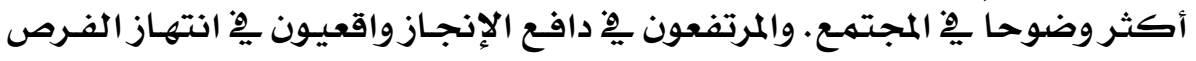

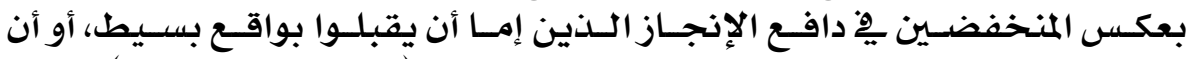
يطمحوا بواقع أكبر بكثير من قدرتهم على تحقيقه (Santrock, J,2003). 


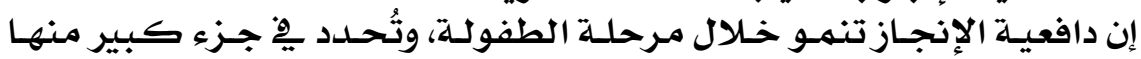

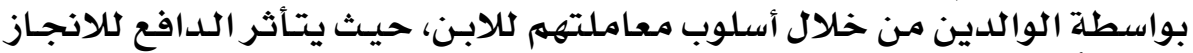

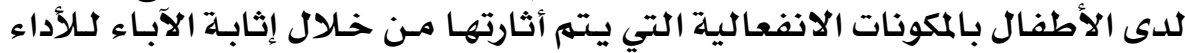

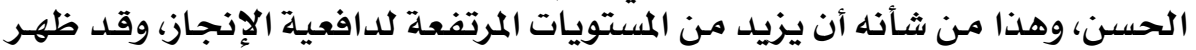

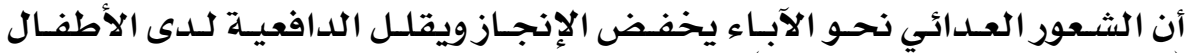

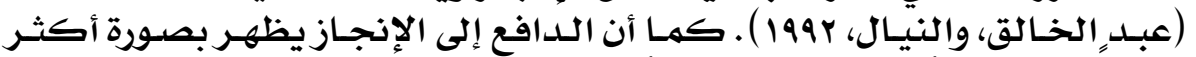

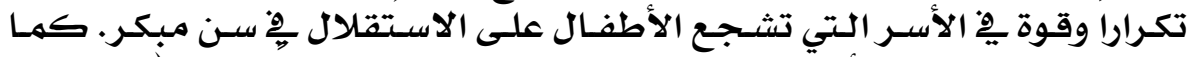

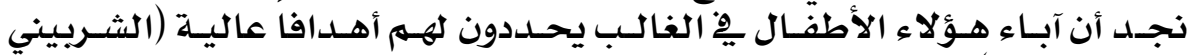

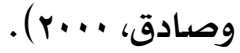

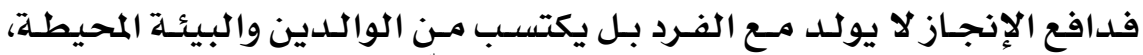

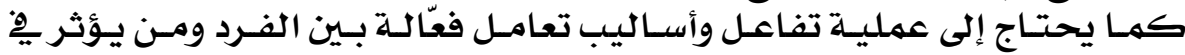

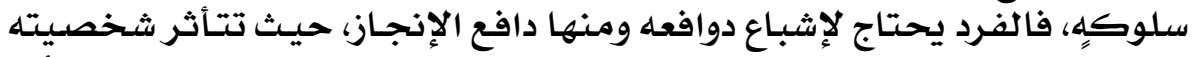

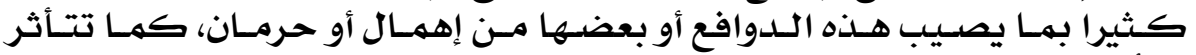

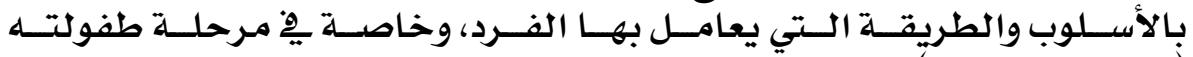
(الصومالي، 1994).

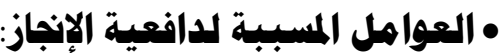

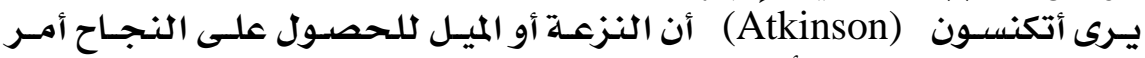

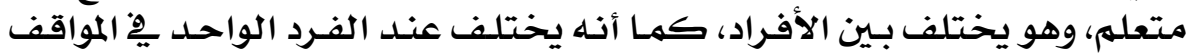

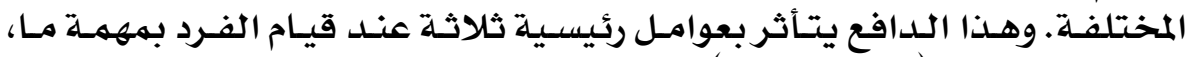

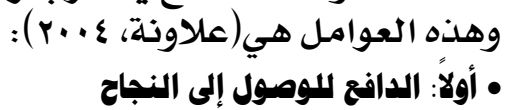

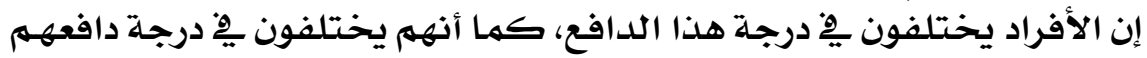

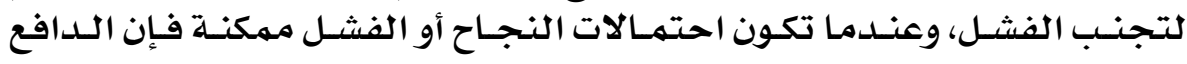

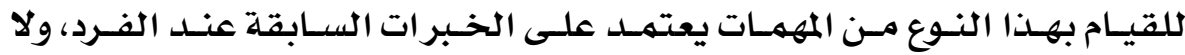

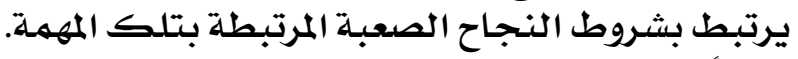

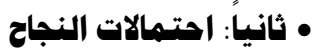

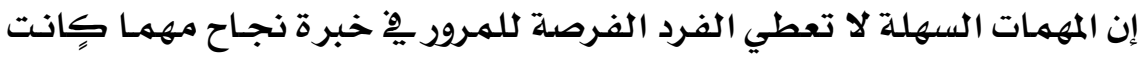

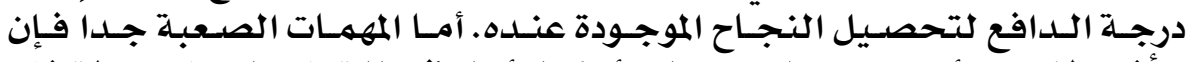

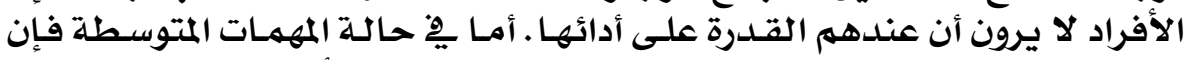

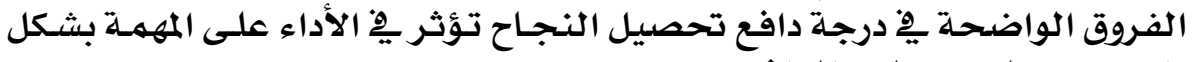

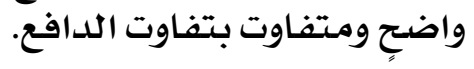

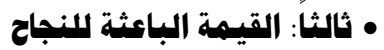

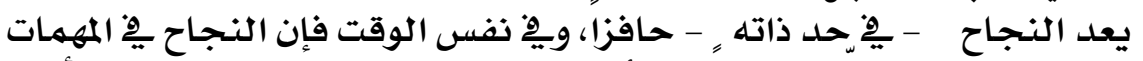

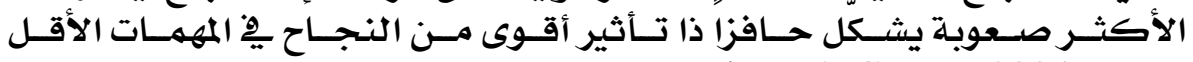
صعوبـ(Petri, H; \& Govern,2004).

\section{$\varepsilon \mid Y$}




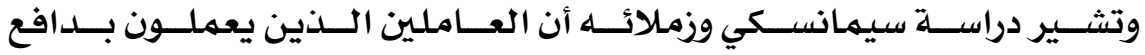

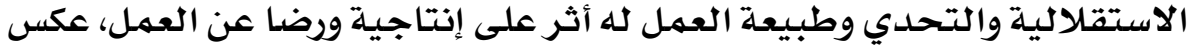

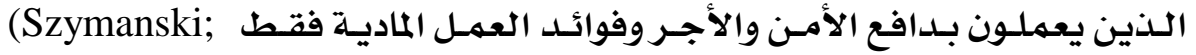
.Enda \& Parker, 1995,130).

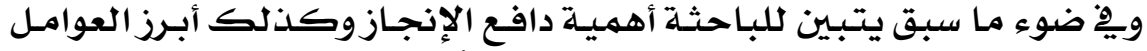

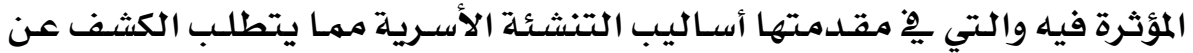

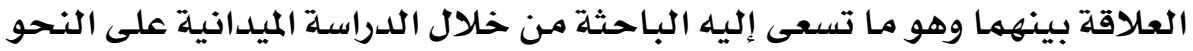
التالي.

\section{• • منهمجية الدراسة وإجراء|تها:

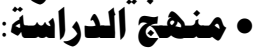

استخلدمت الدراسة المنهج الوصفي باعتباره الأنسب لتحقيق أهدافها. • همتبهـ الدراستة:

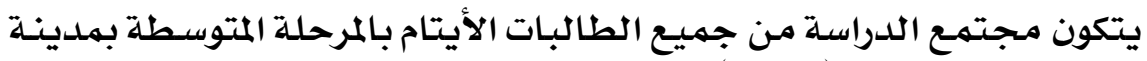

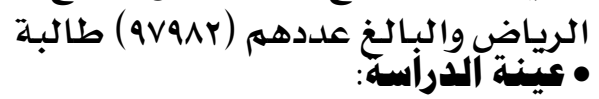

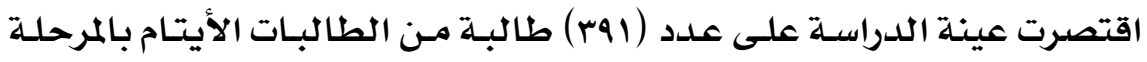

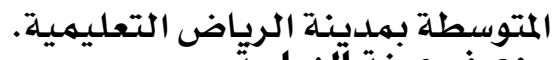
• وصف عينة اللدراسية:

جدول (1) بوضح توزيع افراد العينة حسب (المدرسة)

\begin{tabular}{|c|c|c|}
\hline النسبت المثويت & التكرار & المدرستة \\
\hline \%79.8 & 312 & حكوميت \\
\hline$\% 20.2$ & 79 & أهليت \\
\hline$\% 100$ & 391 & المجموع \\
\hline
\end{tabular}

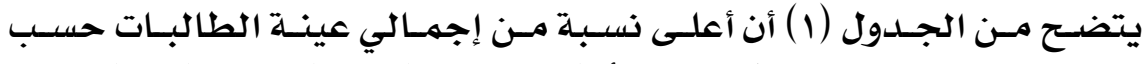

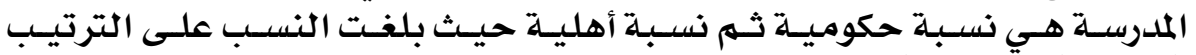
.\%20.2)، (\%79.8)

\begin{tabular}{|c|c|c|}
\hline \multicolumn{3}{|c|}{ جلدول (r) يوضح توزيع افراد العينة حسب (المستوى اللدراسي) } \\
\hline النسبة المئويتة & التكرار & 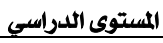 \\
\hline \%27.1 & 106 & السابع \\
\hline$\% 30.7$ & 120 & الثامن \\
\hline$\% 42.2$ & 165 & التاسع \\
\hline$\% 100$ & 391 & المجموع \\
\hline
\end{tabular}

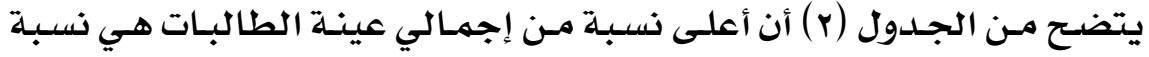

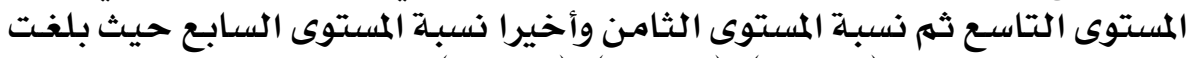

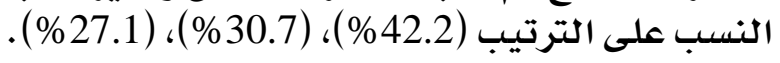




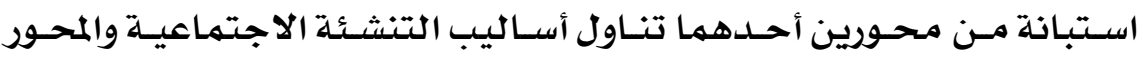

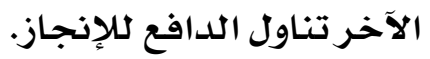

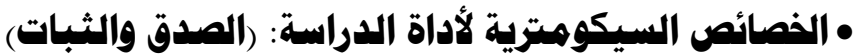

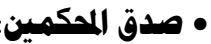

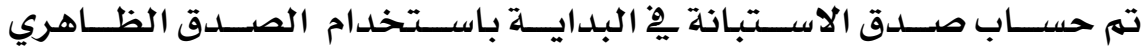

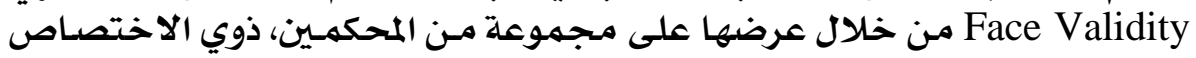

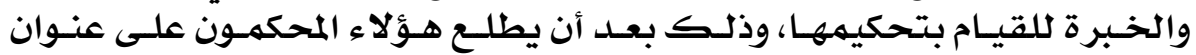

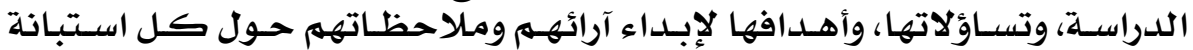

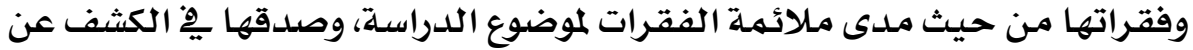

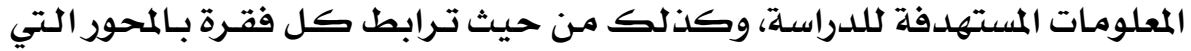

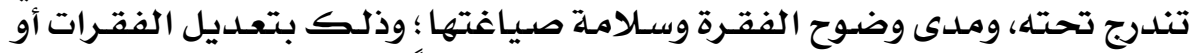

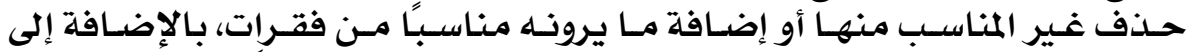

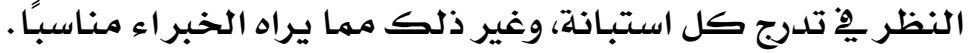

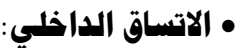

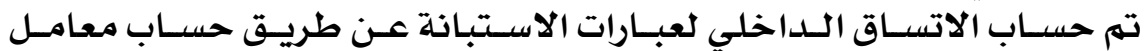

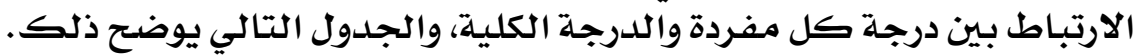

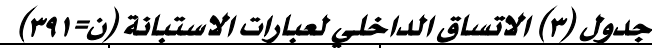

\begin{tabular}{|c|c|c|c|}
\hline معامل الارتباط & العبارة & معامل الارتباط & العبارة \\
\hline .820 & عبارة rr & $.665^{* * *}$ & عبارة| \\
\hline $.759^{* *}$ & عبارةعr & $.614^{* * * 6}$ & عبارةr \\
\hline $.771^{* * *}$ & عبارةة r & $.617^{* * *}$ & عبارةr \\
\hline $.539^{* * * 3}$ & عبارةهM & $.704^{* * *}$ & عبارة؛ \\
\hline $.632^{* * *}$ & مبارة rV & $.526^{* * *}$ & عبارةه \\
\hline $.625^{* * *}$ & عبارةشY & $.703^{* * * *}$ & عبارة7 \\
\hline $.569^{* * *}$ & عبارةهr & $.714^{* * *}$ & عبارة v \\
\hline $.698^{* \% *}$ & عبارة.r & $.194^{* * *}$ & عبارةه \\
\hline $.452^{* * *}$ & عبارةاس & $.792^{* * *}$ & عبارة9 \\
\hline $.764^{3 * 26}$ & عبارةrr & $.697^{* 3 \pi}$ & عبارة.1 \\
\hline $.735^{* *}$ & عبارةrr & $.826^{* * * *}$ & عبارة|| \\
\hline $.705^{* * 1}$ & عبارة؛r & .710 & عبارةr| \\
\hline $.514^{2 * 3 *}$ & مبارةهr & $.717^{* * *}$ & عبارةrا \\
\hline $.688^{8 \%}$ & عبارة rr & $.143^{\text {FF }}$ & عبارةغا \\
\hline $.697^{* * 3}$ & مبارة rV & $.735^{* * *}$ & عبارة010 \\
\hline $.452^{* * \pi}$ & عبارةar & $.807^{* * *}$ & عبارةق1 \\
\hline $.467^{* * *}$ & مبارةهوr & $.758^{* * *}$ & عبارة/VI \\
\hline $.744^{* \% *}$ & عبارة.ئ & $.746^{* * * \%}$ & عبارةشا \\
\hline $.552^{* * *}$ & مبارةاع & $.709^{* * *}$ & عبارة 19 \\
\hline $.525^{* * *}$ & مبارةrا & $.834^{* * *}$ & عبارة.r \\
\hline $.746^{* * 1 \%}$ & عبارة"rع & $.642^{* * \pi}$ & عبارةا M \\
\hline $.821^{* * *}$ & عبارةءء & $.726^{* * *}$ & عبارةr \\
\hline
\end{tabular}

هـ تعني أن معامل الارتباط دال عند ا... 


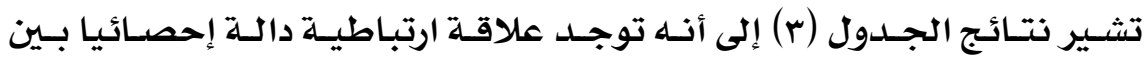

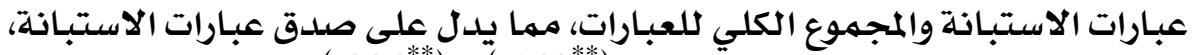

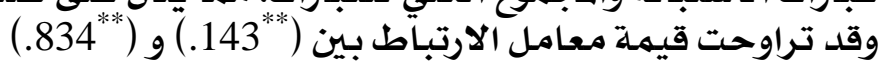

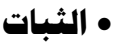

تم التحقق من ثبات الأداة باسـتخدام معادلـة ألفـا لكرونبـاخ، والجـدول التـالي يوضسح ذلك.

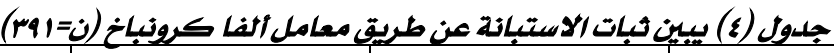

\begin{tabular}{|c|c|c|c|}
\hline درجت الثبات & معامل الثبات & عدد العبارات & \\
\hline مرتفعن & .788 & 24 & الأول \\
\hline مرتفعتة & .967 & 20 & الثانى \\
\hline مرتفعتة & .930 & 44 & الإجمائ \\
\hline
\end{tabular}

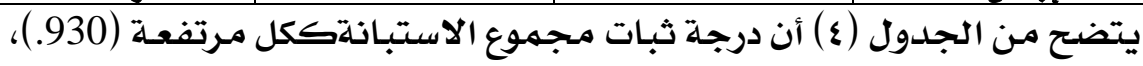

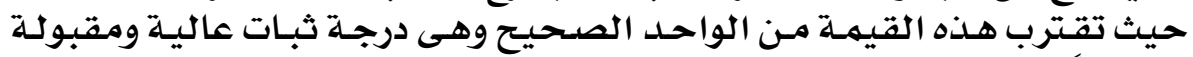

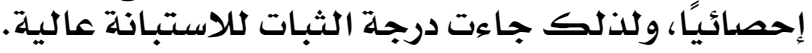

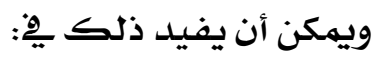

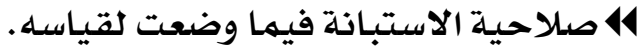

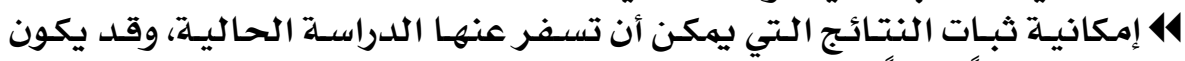

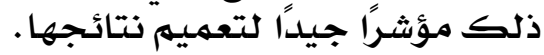

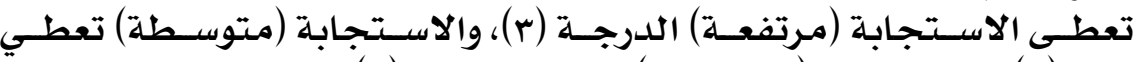

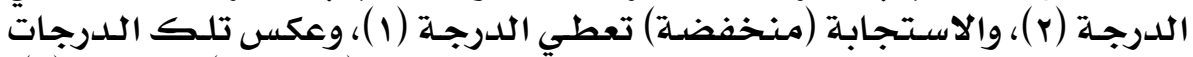

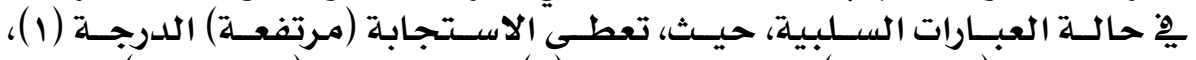

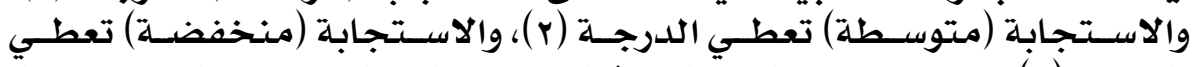

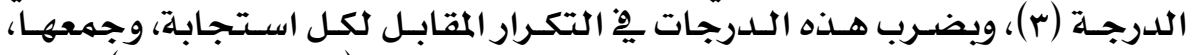

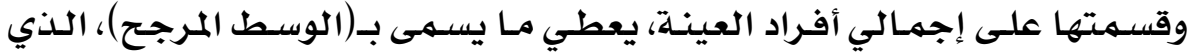

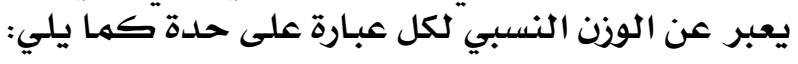

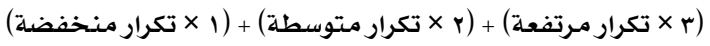

$$
\text { عدد أفراد العينة }
$$$$
\text { التقدير الرقمي لكل عبارة = }
$$

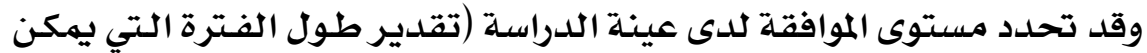

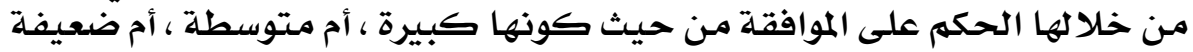

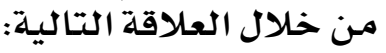

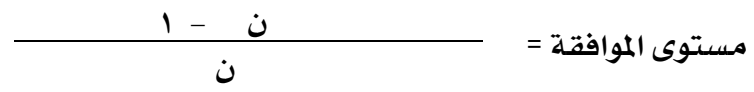

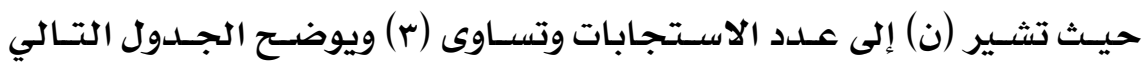

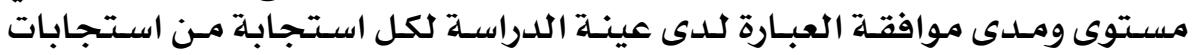

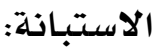




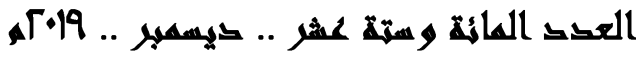

جلدول (o) يوضح مستوى الموافقة للى عينة اللدراسة

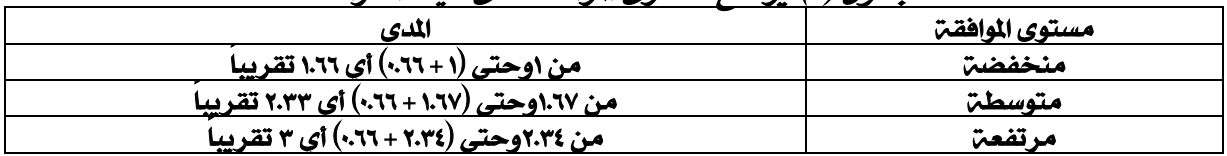

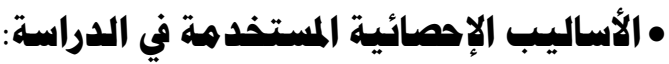

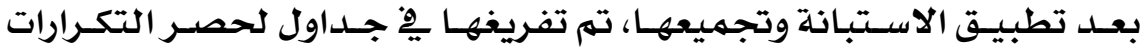

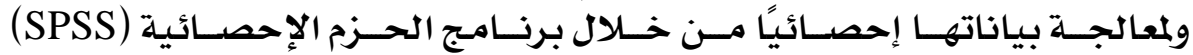
Statistical Package for Social Sciences

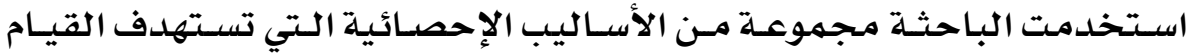

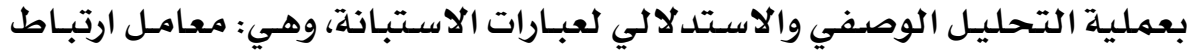

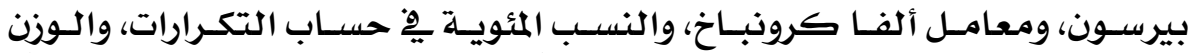

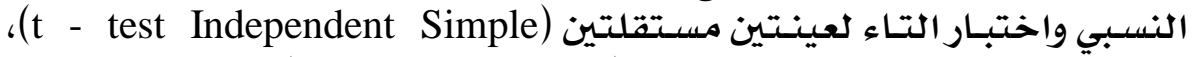

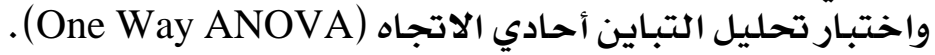

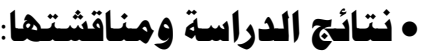

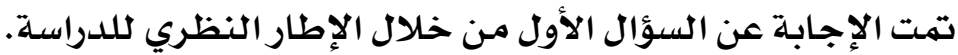

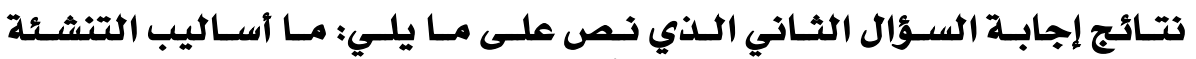

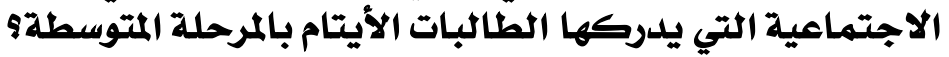

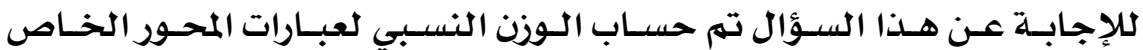

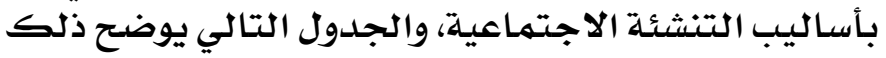

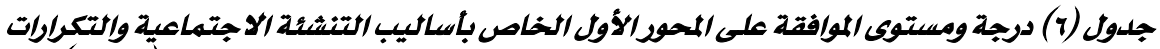

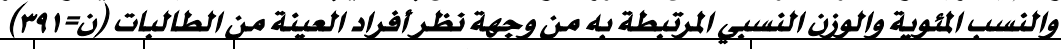

\begin{tabular}{|c|c|c|c|c|c|c|c|c|c|c|}
\hline \multirow{3}{*}{ مستوفت } & \multirow{3}{*}{ العبارتيب } & \multirow{3}{*}{ النسبي } & \multicolumn{6}{|c|}{ درجت الموافقت } & \multirow{3}{*}{ العبارة } & \multirow[b]{3}{*}{$p$} \\
\hline & & & \multicolumn{2}{|c|}{ منخفضتة } & \multicolumn{2}{|c|}{ متوسطتً } & \multicolumn{2}{|c|}{ مرتفعت } & & \\
\hline & & & $\%$ & ك & $\%$ & ك & $\%$ & ك & & \\
\hline ضعيفتة & 19 & $\begin{array}{c}1.63 \\
94\end{array}$ & $\begin{array}{c}59.10 \\
\%\end{array}$ & 231 & $\begin{array}{c}17.90 \\
\%\end{array}$ & 70 & $\begin{array}{c}23.00 \\
\%\end{array}$ & 90 & 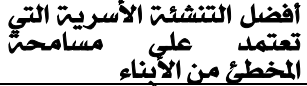 & 1 \\
\hline ضعيفت & 20 & $\begin{array}{c}1.63 \\
43\end{array}$ & $\begin{array}{c}63.40 \\
\%\end{array}$ & 248 & $\begin{array}{c}9.70 \\
\%\end{array}$ & 38 & $\begin{array}{c}26.90 \\
\%\end{array}$ & 105 & 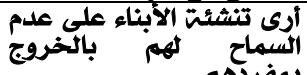 & r \\
\hline متوسطتة & 17 & $\begin{array}{c}1.74 \\
17\end{array}$ & $\begin{array}{c}\mathbf{5 0 . 6 0} \\
\%\end{array}$ & 198 & $\begin{array}{c}24.60 \\
\%\end{array}$ & 96 & $\begin{array}{c}24.80 \\
\%\end{array}$ & 97 & 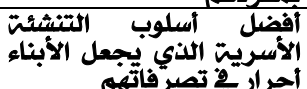 & $r$ \\
\hline ضعيفت & 18 & $\begin{array}{c}1.65 \\
22\end{array}$ & $\begin{array}{c}57.00 \\
\%\end{array}$ & 223 & $\begin{array}{c}20.70 \\
\%\end{array}$ & 81 & $\begin{array}{c}22.30 \\
\%\end{array}$ & 87 & 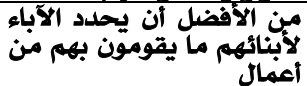 & $\varepsilon$ \\
\hline ضعيفت & 22 & $\begin{array}{c}1.52 \\
69\end{array}$ & $\begin{array}{c}\mathbf{5 2 . 2 0} \\
\%\end{array}$ & 204 & $\begin{array}{c}43.00 \\
\%\end{array}$ & $\begin{array}{c}16 \\
8\end{array}$ & $\begin{array}{c}4.90 \\
\%\end{array}$ & 19 & 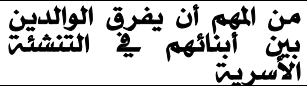 & - \\
\hline متوسطت & 1 & $\begin{array}{c}2.32 \\
99\end{array}$ & $\begin{array}{c}28.60 \\
\%\end{array}$ & 112 & $\begin{array}{c}9.70 \\
\%\end{array}$ & 38 & $\begin{array}{c}\mathbf{6 1 . 6 0} \\
\%\end{array}$ & 241 & 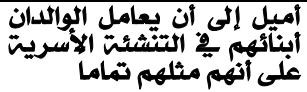 & r \\
\hline
\end{tabular}




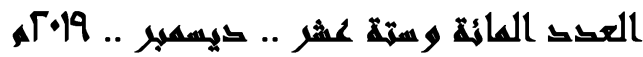

\begin{tabular}{|c|c|c|c|c|c|c|c|c|c|c|}
\hline \multirow{3}{*}{ الموافتقت } & \multirow{3}{*}{ العبارات } & \multirow{3}{*}{ 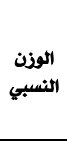 } & \multicolumn{6}{|c|}{ درجت الموافقت } & \multirow{3}{*}{ العبارة } & \multirow[b]{3}{*}{$p$} \\
\hline & & & \multicolumn{2}{|c|}{ منخفضت } & \multicolumn{2}{|c|}{ متوسطتة } & \multicolumn{2}{|c|}{ مرتفعت } & & \\
\hline & & & $\%$ & ك & $\%$ & ك & $\%$ & ك & & \\
\hline متوسطت & 10 & $\begin{array}{c}2.22 \\
25\end{array}$ & $\begin{array}{c}26.60 \\
\%\end{array}$ & 104 & $\begin{array}{c}24.60 \\
\%\end{array}$ & 96 & $\begin{array}{c}48.80 \\
\%\end{array}$ & 191 & 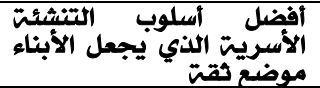 & $v$ \\
\hline ضعيضت & 23 & $\begin{array}{c}1.46 \\
29\end{array}$ & $\begin{array}{c}64.70 \\
\%\end{array}$ & 253 & $\begin{array}{c}24.30 \\
\%\end{array}$ & 95 & $\begin{array}{c}11.00 \\
\%\end{array}$ & 43 & 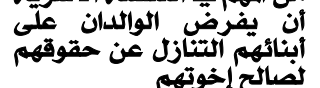 & $\wedge$ \\
\hline متوسطت & 4 & $\begin{array}{c}2.31 \\
46\end{array}$ & $\begin{array}{c}27.60 \\
\%\end{array}$ & 108 & $\begin{array}{c}13.30 \\
\%\end{array}$ & 52 & $\begin{array}{c}\mathbf{5 9 . 1 0} \\
\%\end{array}$ & 231 & 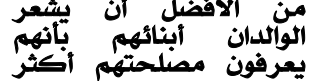 & 9 \\
\hline متوسطت & 16 & $\begin{array}{c}1.97 \\
19\end{array}$ & $\begin{array}{c}44.00 \\
\%\end{array}$ & 172 & $\begin{array}{c}14.80 \\
\%\end{array}$ & 58 & $\begin{array}{c}41.20 \\
\%\end{array}$ & 161 & 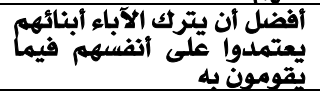 & 1. \\
\hline متوسطت & 3 & $\begin{array}{c}2.31 \\
46\end{array}$ & $\begin{array}{c}27.60 \\
\%\end{array}$ & 108 & $\begin{array}{c}13.30 \\
\%\end{array}$ & 52 & $\begin{array}{c}\mathbf{5 9 . 1 0} \\
\%\end{array}$ & 231 & 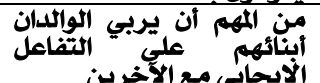 & $" 1$ \\
\hline متوسطت & 7 & $\begin{array}{c}2.26 \\
85\end{array}$ & $\begin{array}{c}28.10 \\
\%\end{array}$ & 110 & $\begin{array}{c}16.90 \\
\%\end{array}$ & 66 & $\begin{array}{c}55.00 \\
\%\end{array}$ & 215 & 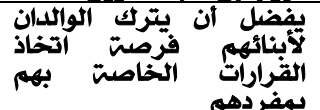 & ir \\
\hline متوسطت & 8 & $\begin{array}{c}2.24 \\
81\end{array}$ & $\begin{array}{c}28.40 \\
\%\end{array}$ & 111 & $\begin{array}{c}18.40 \\
\%\end{array}$ & 72 & $\begin{array}{c}\mathbf{5 3 . 2 0} \\
\%\end{array}$ & 208 & 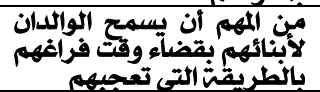 & Ir \\
\hline ضعيفة & 24 & $\begin{array}{c}1.45 \\
52\end{array}$ & $\begin{array}{c}\mathbf{6 5 . 5 0} \\
\%\end{array}$ & 256 & $\begin{array}{c}23.50 \\
\%\end{array}$ & 92 & $\begin{array}{c}11.00 \\
\%\end{array}$ & 43 & 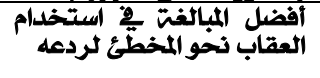 & 18 \\
\hline متوسطت & 14 & $\begin{array}{c}2.06 \\
65\end{array}$ & $\begin{array}{c}39.40 \\
\%\end{array}$ & 154 & $\begin{array}{c}14.60 \\
\%\end{array}$ & 57 & $\begin{array}{c}46.00 \\
\%\end{array}$ & 180 & 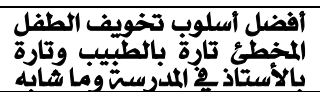 & 10 \\
\hline متوسطت & 2 & $\begin{array}{c}2.32 \\
23\end{array}$ & $\begin{array}{c}27.60 \\
\%\end{array}$ & 108 & $\begin{array}{c}12.50 \\
\%\end{array}$ & 49 & $\begin{array}{c}\mathbf{5 9 . 8 0} \\
\%\end{array}$ & 234 & يعتمل إلى على نفس ترك حتى الطفل & 17 \\
\hline متوسطت & 12 & $\begin{array}{c}2.18 \\
67\end{array}$ & $\begin{array}{c}33.50 \\
\%\end{array}$ & 131 & $\begin{array}{c}14.30 \\
\%\end{array}$ & 56 & $\begin{array}{c}\mathbf{5 2 . 2 0} \\
\%\end{array}$ & 204 & |'الصنماع & iv \\
\hline متوسطت & 9 & $\begin{array}{c}2.23 \\
53\end{array}$ & $\begin{array}{c}29.70 \\
\%\end{array}$ & 116 & $\begin{array}{c}17.10 \\
\%\end{array}$ & 67 & $\begin{array}{c}\mathbf{5 3 . 2 0} \\
\%\end{array}$ & 208 & نهط & in \\
\hline متوسطت & 15 & $\begin{array}{c}2.05 \\
63\end{array}$ & $\begin{array}{c}29.40 \\
\%\end{array}$ & 115 & $\begin{array}{c}35.50 \\
\%\end{array}$ & $\begin{array}{c}13 \\
9\end{array}$ & $\begin{array}{c}35.00 \\
\%\end{array}$ & 137 & 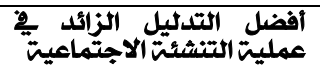 & 19 \\
\hline متوسطتة & 6 & $\begin{array}{c}2.27 \\
62\end{array}$ & $\begin{array}{c}30.90 \\
\%\end{array}$ & 121 & $\begin{array}{c}10.50 \\
\%\end{array}$ & 41 & $\begin{array}{c}\mathbf{5 8 . 6 0} \\
\%\end{array}$ & 229 & 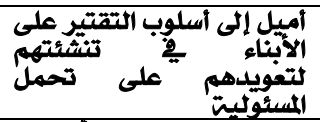 & r. \\
\hline ضعيفت & 21 & $\begin{array}{c}1.62 \\
40\end{array}$ & $\begin{array}{c}64.20 \\
\%\end{array}$ & 251 & $\begin{array}{c}9.20 \\
\%\end{array}$ & 36 & $\begin{array}{c}26.60 \\
\%\end{array}$ & 104 & 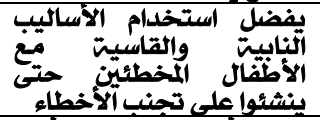 & $n$ \\
\hline متوسطت & 11 & $\begin{array}{c}2.20 \\
72\end{array}$ & $\begin{array}{c}24.60 \\
\%\end{array}$ & 96 & $\begin{array}{c}30.20 \\
\%\end{array}$ & $\begin{array}{c}11 \\
8\end{array}$ & $\begin{array}{c}45.30 \\
\%\end{array}$ & 177 & 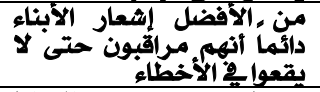 & rr \\
\hline متوسطت & 5 & $\begin{array}{c}2.30 \\
95\end{array}$ & $\begin{array}{c}28.40 \\
\%\end{array}$ & 111 & $\begin{array}{c}12.30 \\
\%\end{array}$ & 48 & $\begin{array}{c}\mathbf{5 9 . 3 0} \\
\%\end{array}$ & 232 & 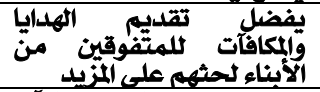 & $r$ \\
\hline متوسطت & 13 & $\begin{array}{c}2.16 \\
62\end{array}$ & $\begin{array}{c}34.00 \\
\%\end{array}$ & 133 & $\begin{array}{c}15.30 \\
\%\end{array}$ & 60 & $\begin{array}{c}\mathbf{5 0 . 6 0} \\
\%\end{array}$ & 198 & تلأبناءئ يعودهم الثلكسل والمكافآت & rq \\
\hline
\end{tabular}




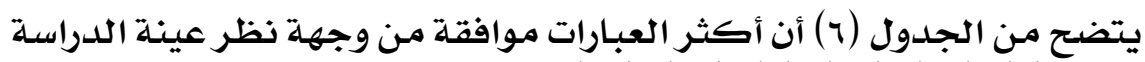

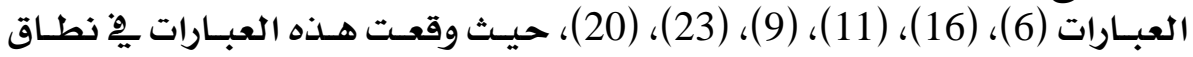

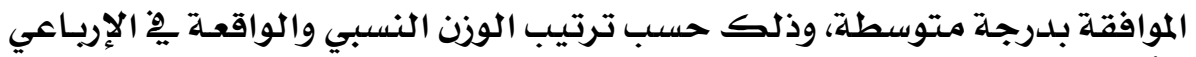

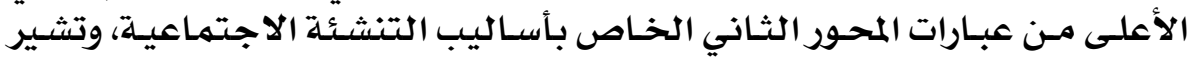

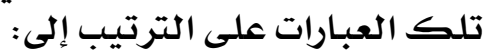

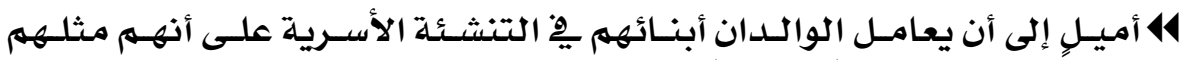

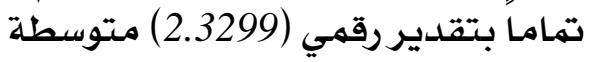

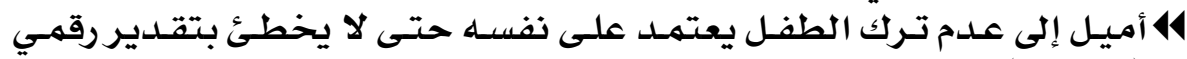

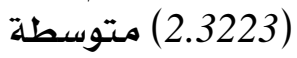
14 مـن المهم أن يربي الوالدان أبنائهم على التفاعل الإيجابي مـع الآخرين بتقـــير

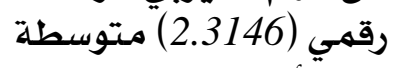

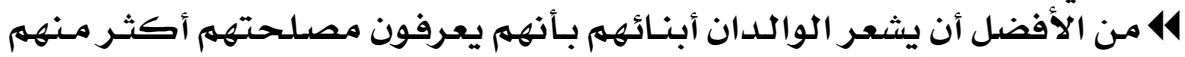

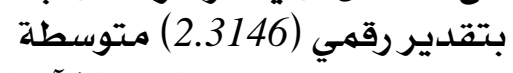

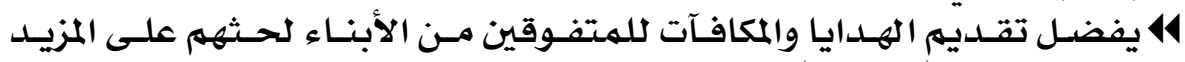

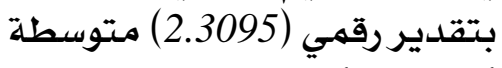

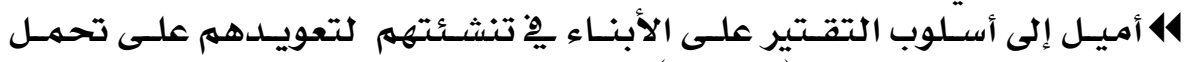
المسئولية بتقدير رقهمي (2.2762) متتوسطة الابنساء

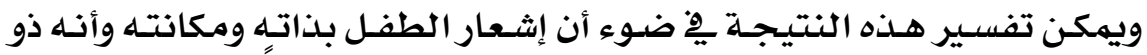

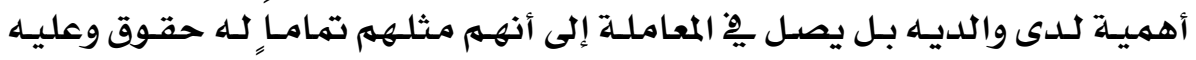

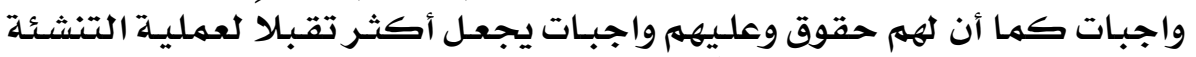

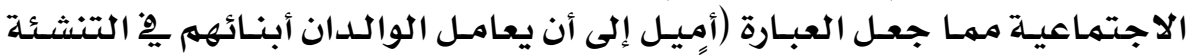

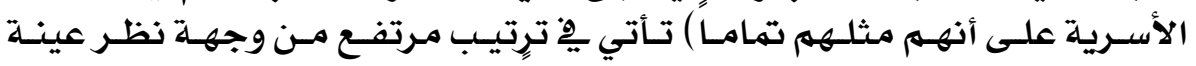

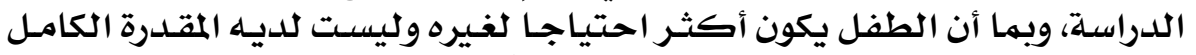

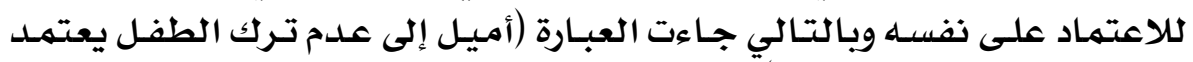

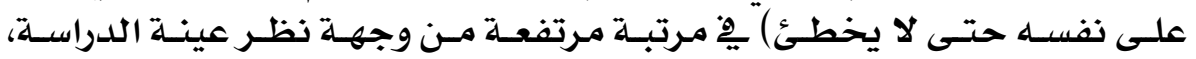

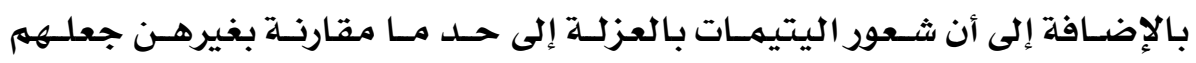

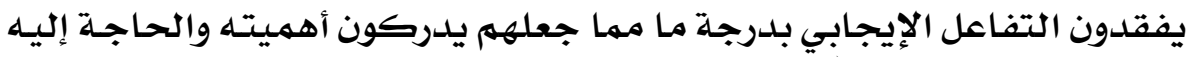

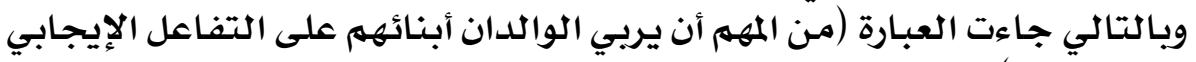

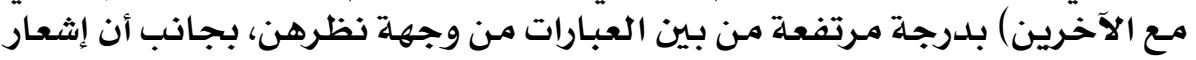

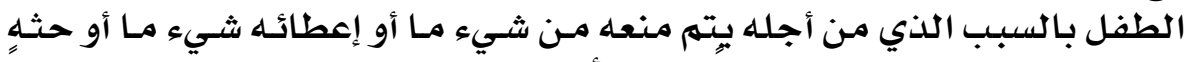

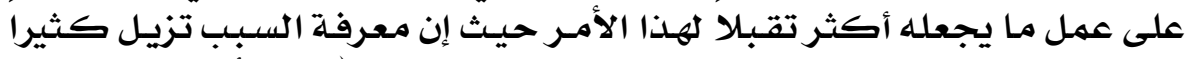

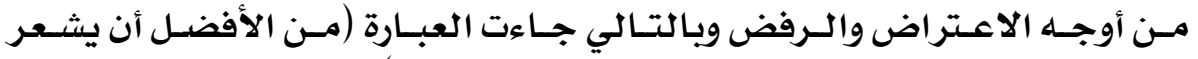

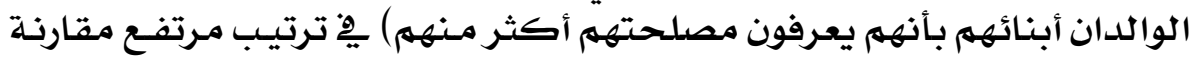

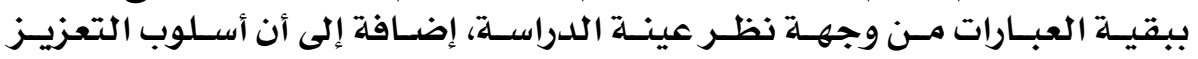




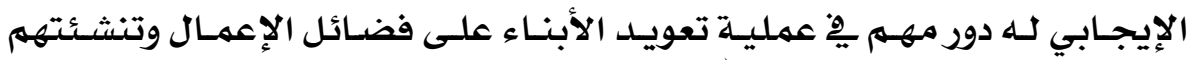

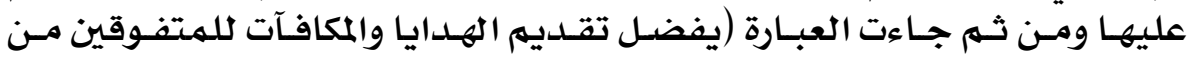

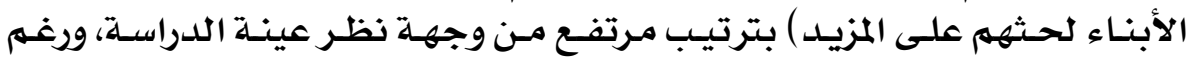

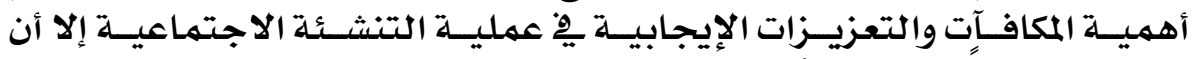

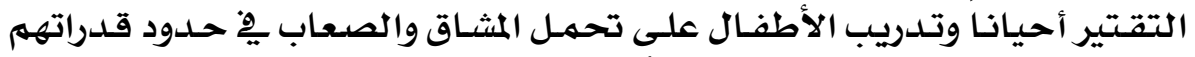

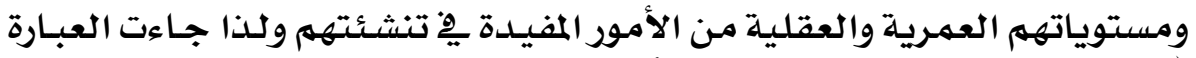

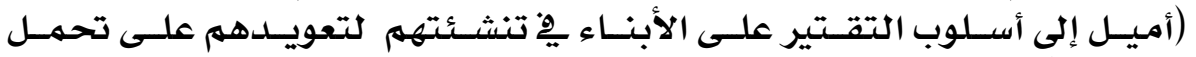

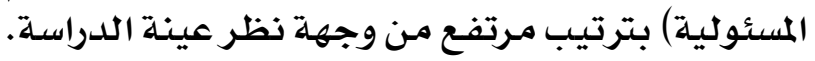

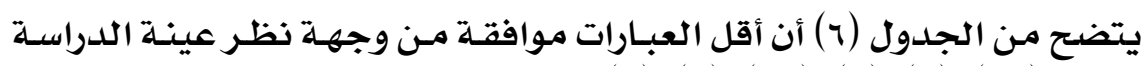

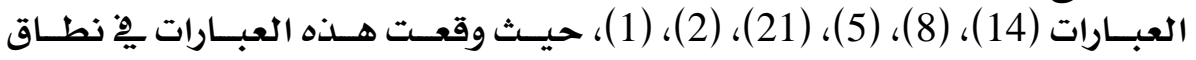

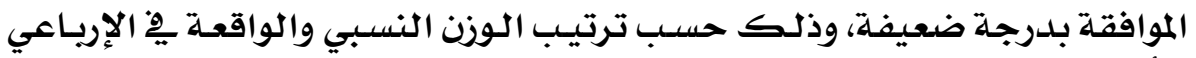

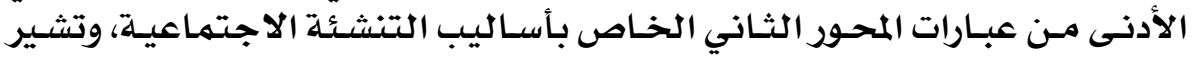

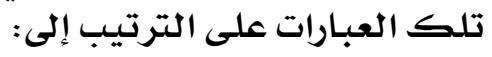

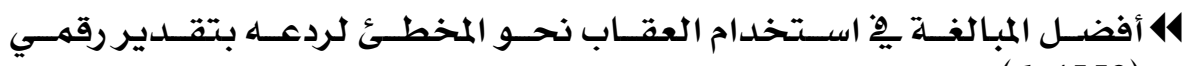
(1.4552)

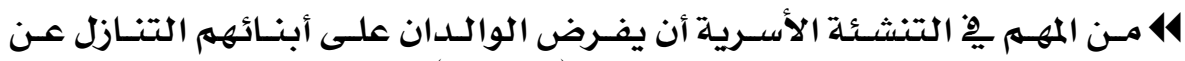

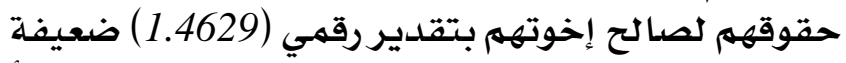

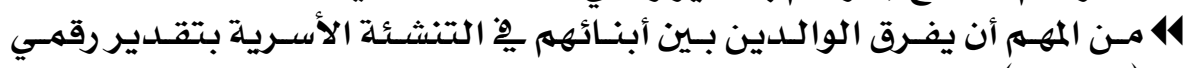
(1.5269)

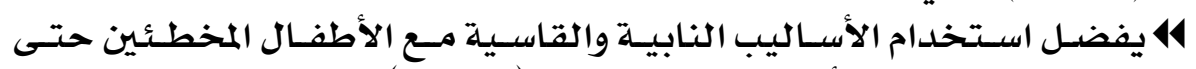

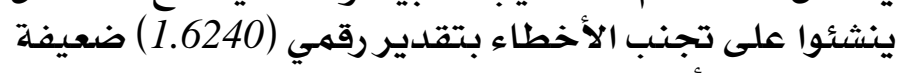

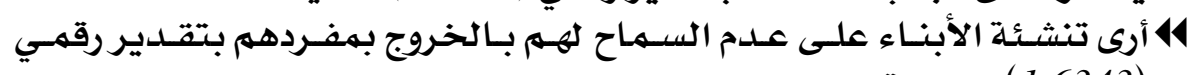
(1.6343)

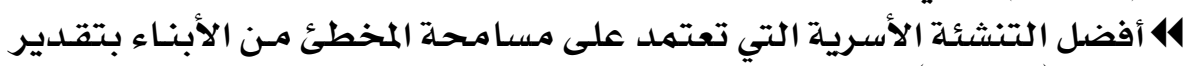
رقمي (1.6394) ضعيفة (1.6نشية

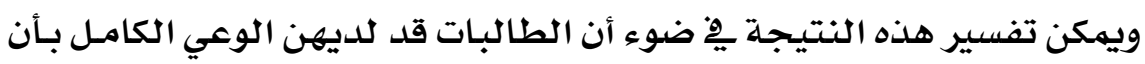

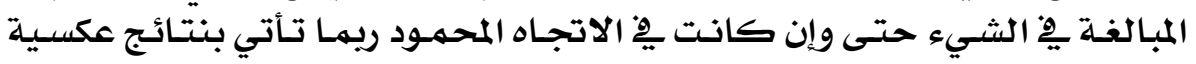

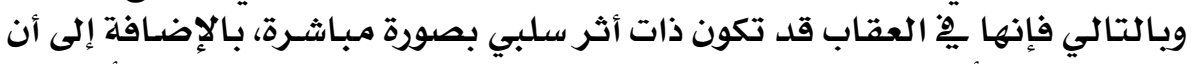

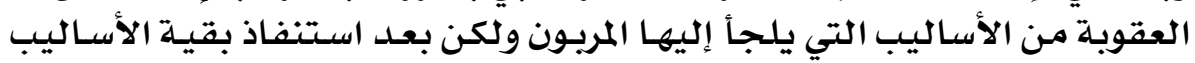

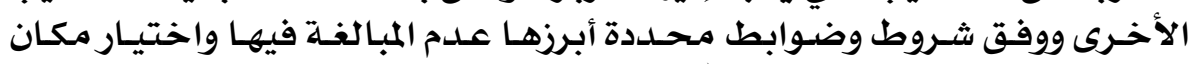

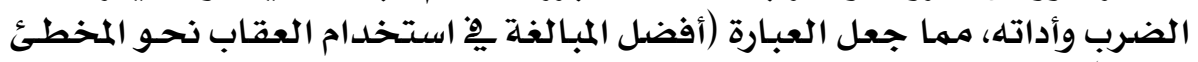

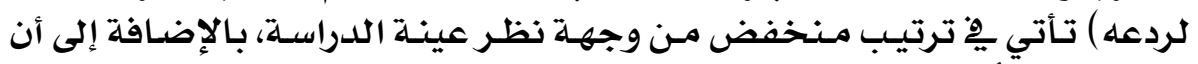

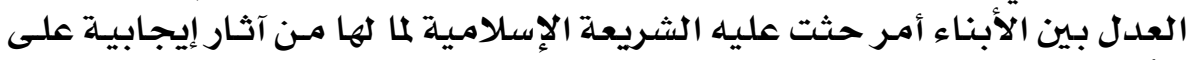

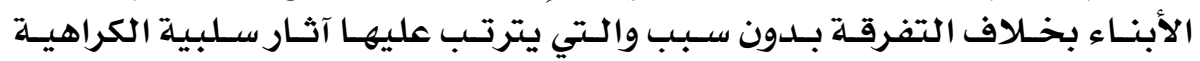

\section{$\varepsilon 19$}




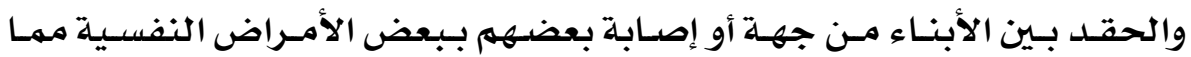

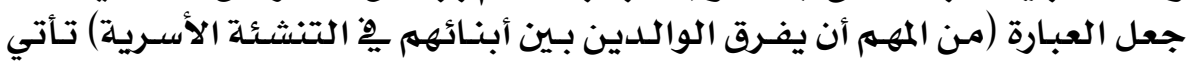

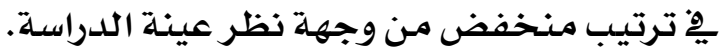

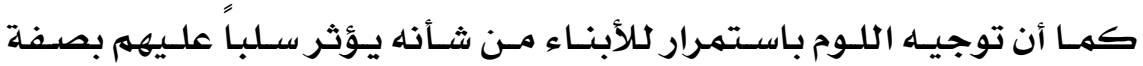

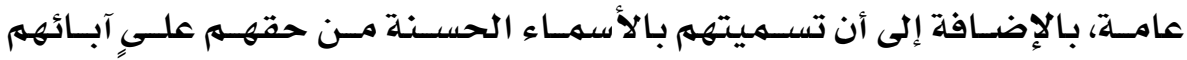

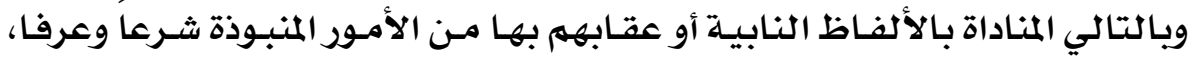

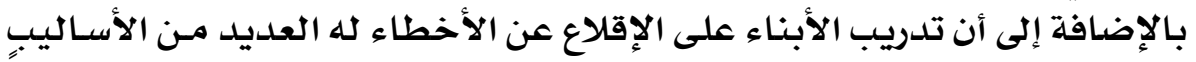

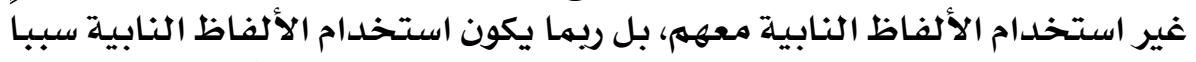

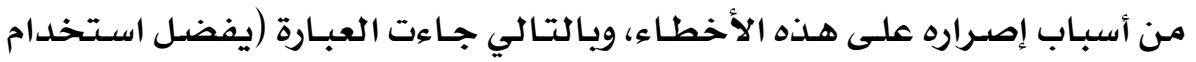

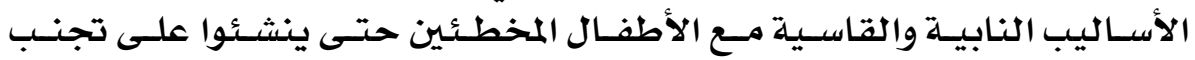

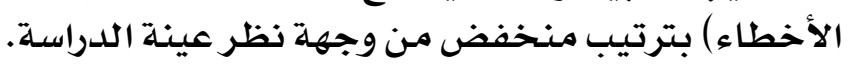

إضافة إلى مـا سبق فإن الأطفال يكون لديهن احتيـاج دائم للعبـ والترفيـه، بـل

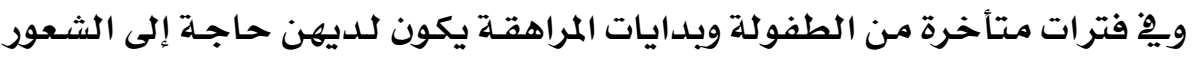

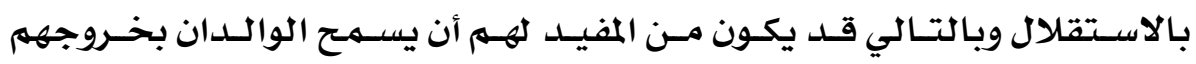

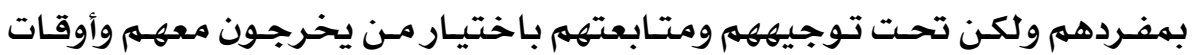

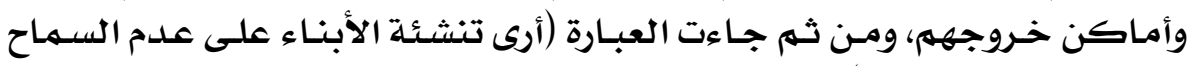

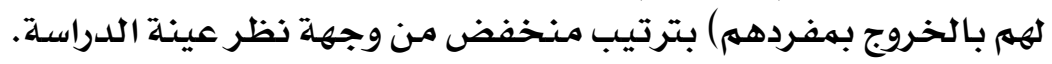

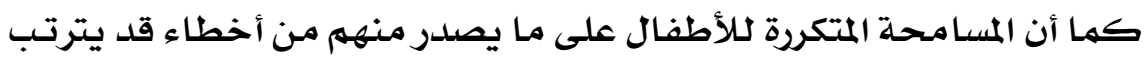

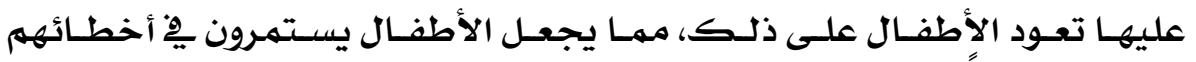

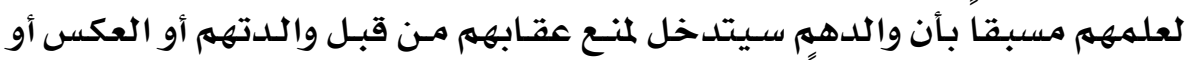

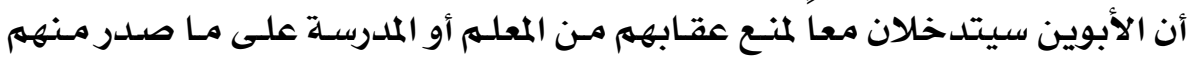

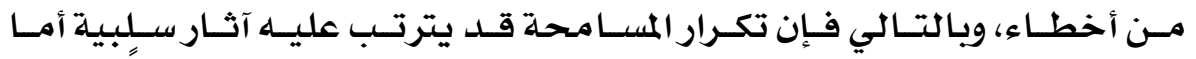

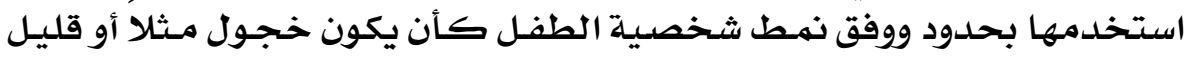

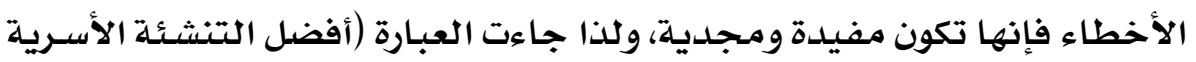

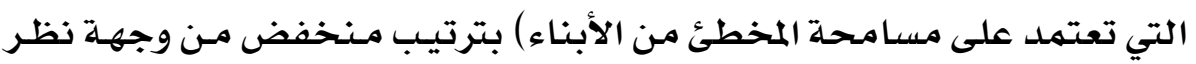

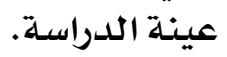

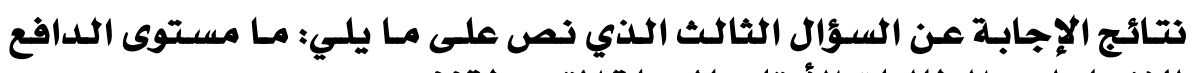

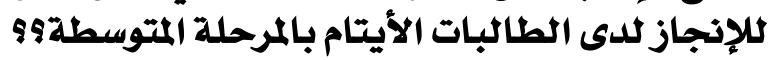

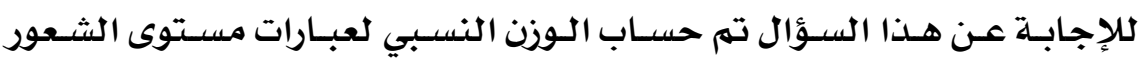

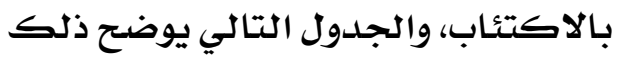

\section{$\varepsilon Y$}




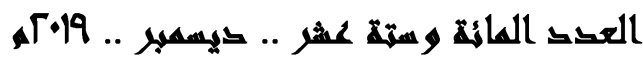

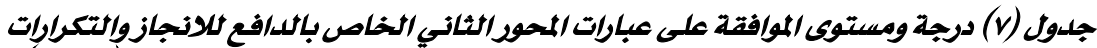

والنسب المئوبية والوزن النسبي المرتبطة به من وجهة نظر عينة اللدراسة من الطالبات (ن = (ra)

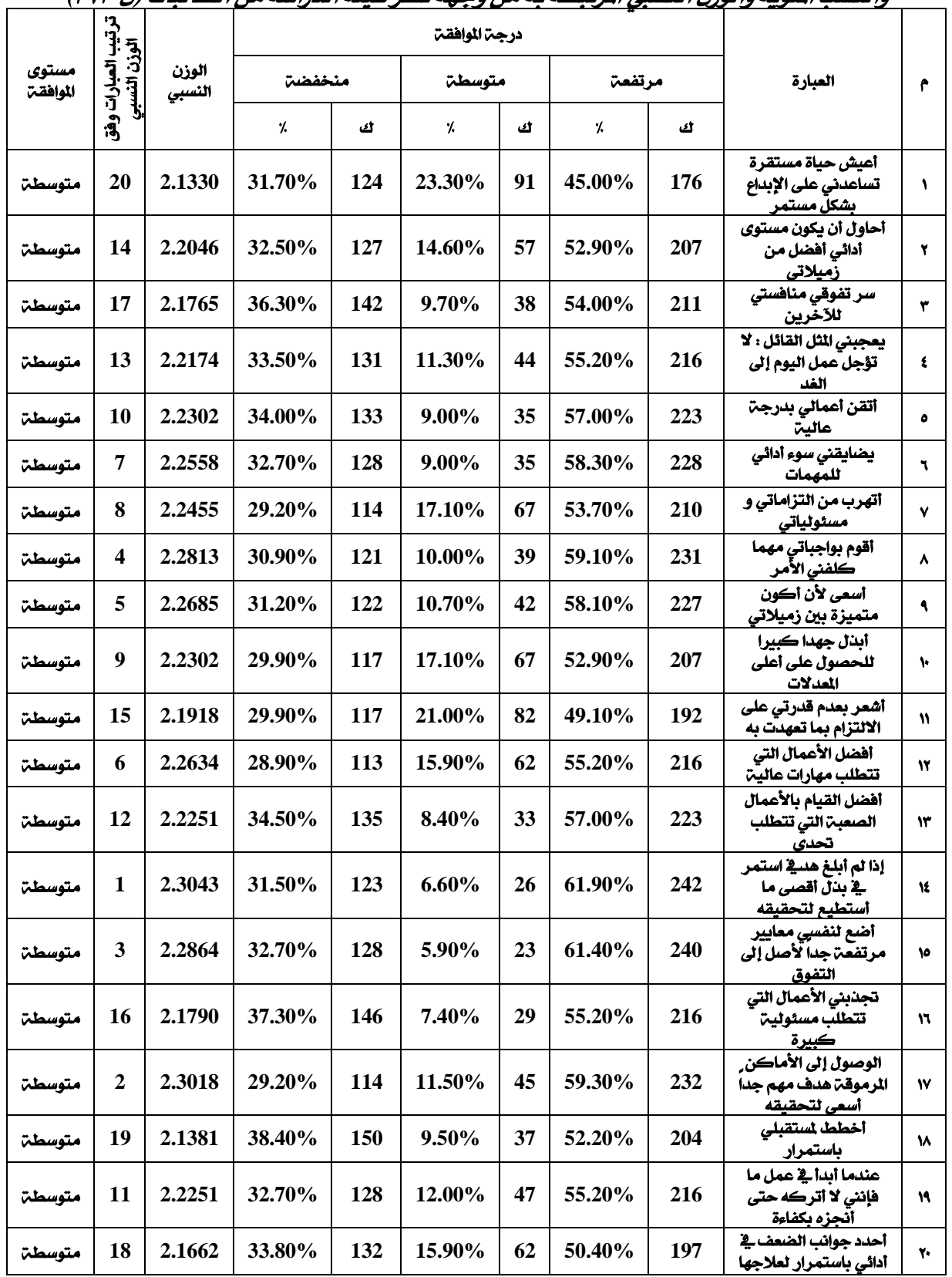

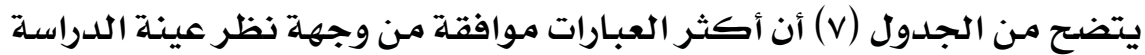

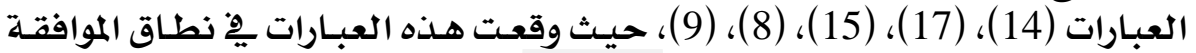




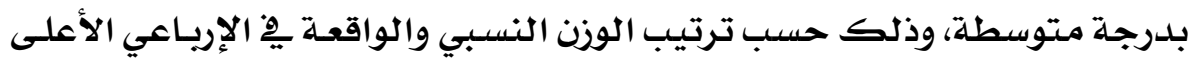

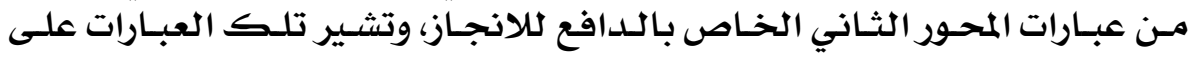

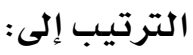

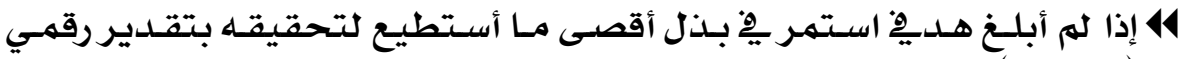

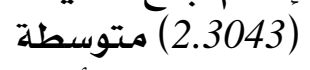
4 الوصول إلى الأماكن المرموقة هدف مهمه جداً أسعى لتحقيقـه بتقدير رقمـي (2.3018) متوسطة الأماطن 4 أضع لنفسي معـايير مـرتفعـة جـداً لأصل إلى التفوق بتقدير رقمهي (2.2864) 4 أقوم بواجباتي مهما كلفني الأمر بتقدير رقهمي (2.2813) متوسطة

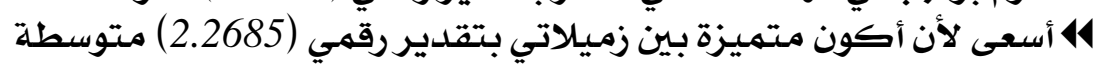

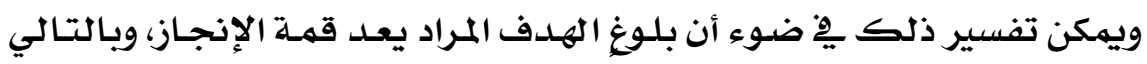

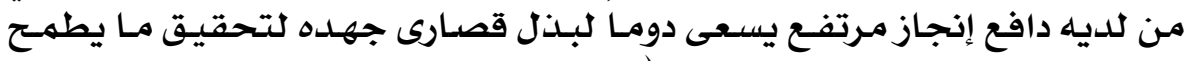

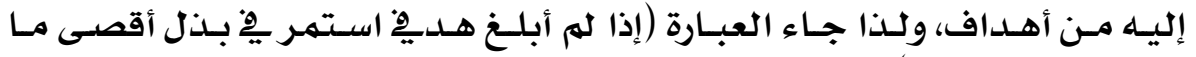

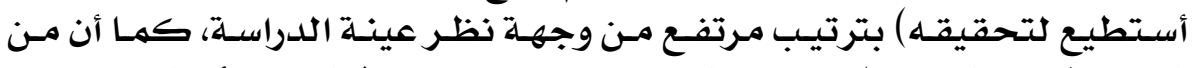

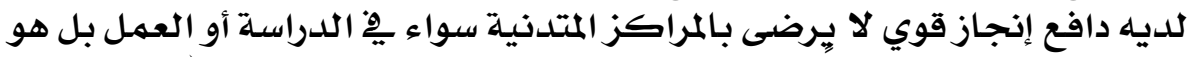

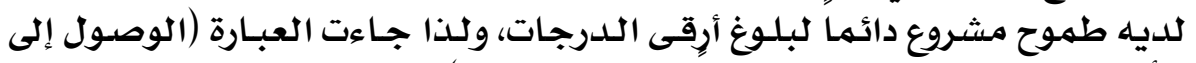

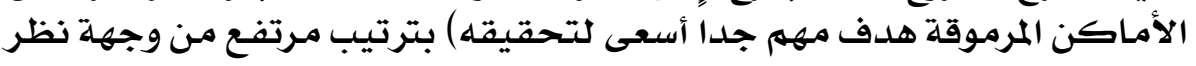

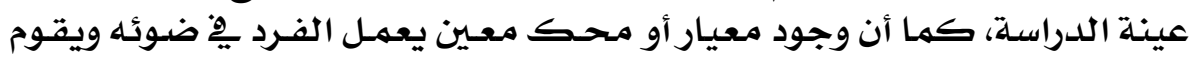

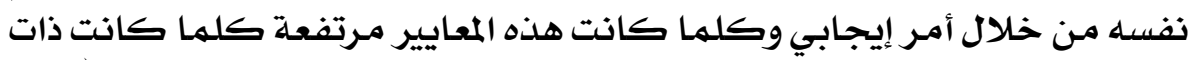

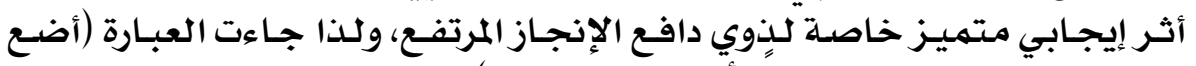

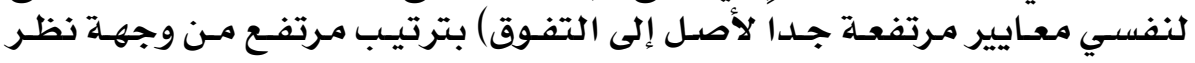

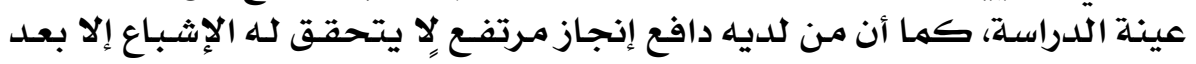

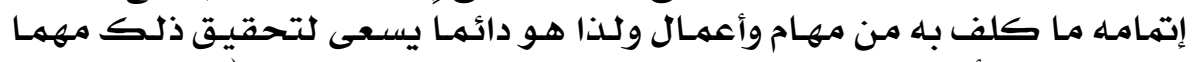

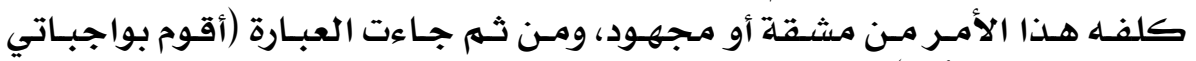

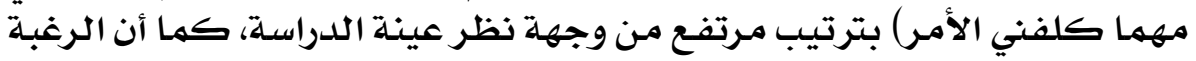

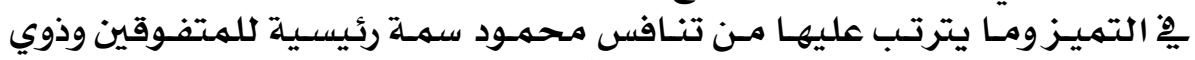

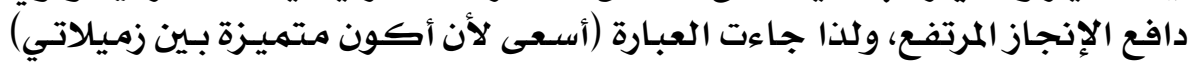

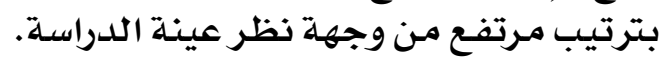

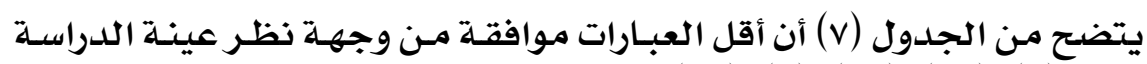

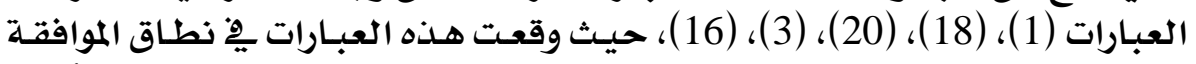

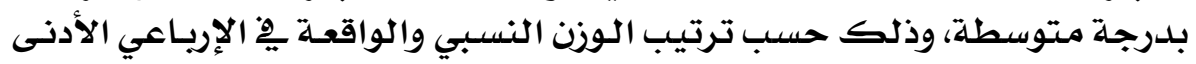

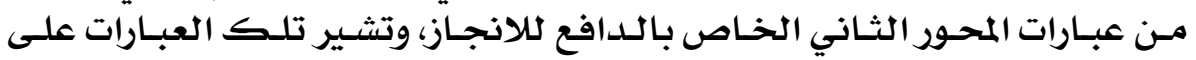

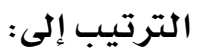




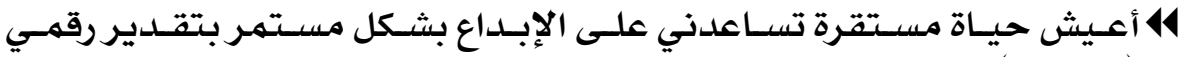

$$
\text { (2.1330) متوسطة مياة مبلقيرة }
$$

41 أخطط لمستقبلي باستهمرار بتقدير رقهي (2.1381) متوسطة

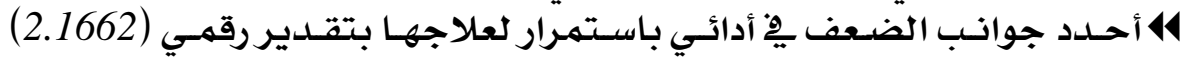
متوسطة

\$ سـر تفوقي منافستي لكلآخرين بتقدير رقهي (2.1765) متوسطة

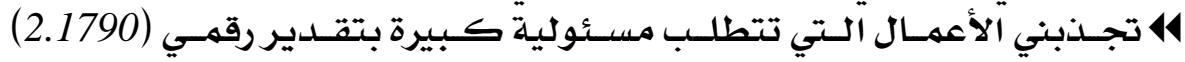
متوسطة

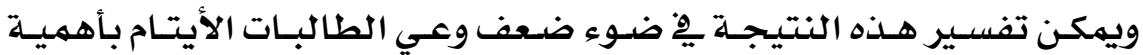

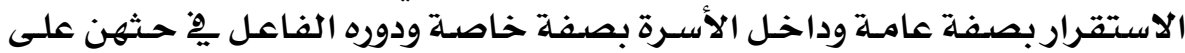

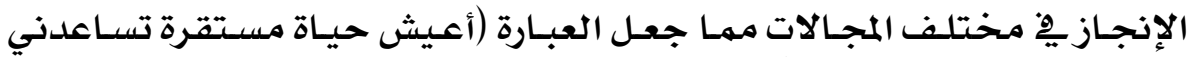

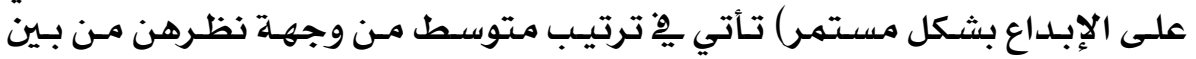

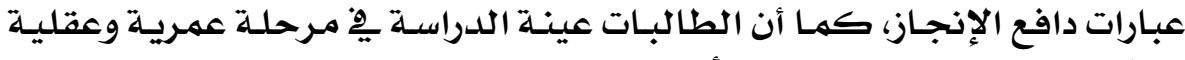

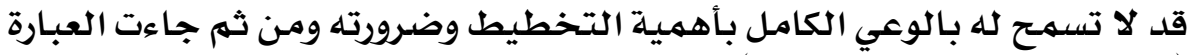

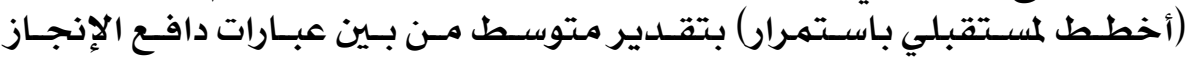

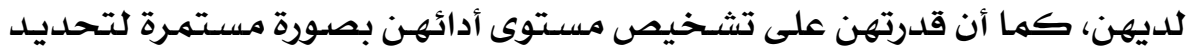

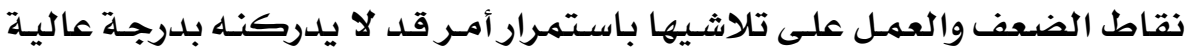

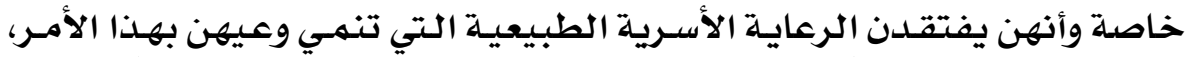

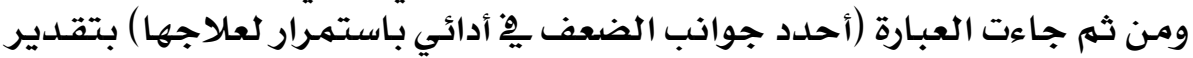

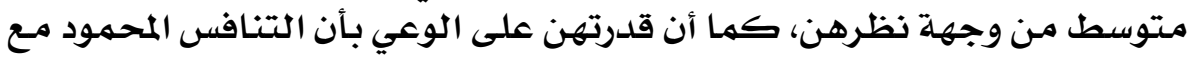

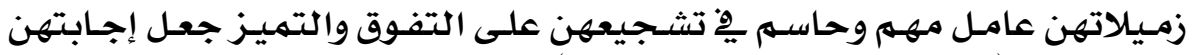

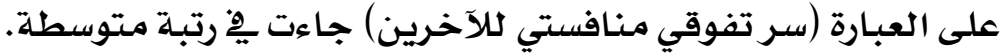

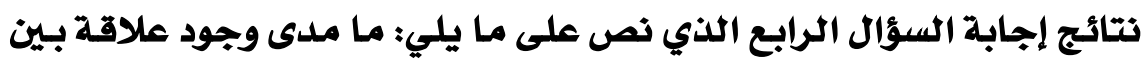

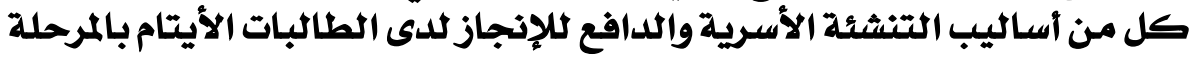

المتوسطة من

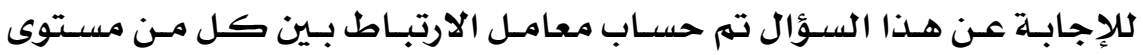

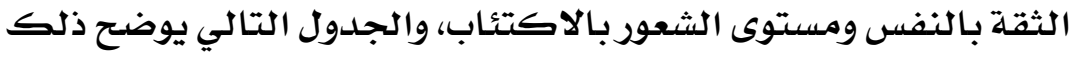

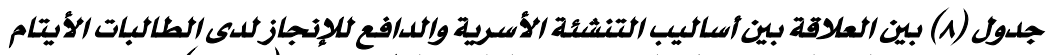

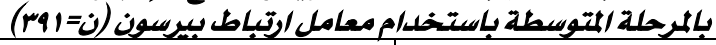

مقياس الشعور بالاكتئاب للدي المتعافين من الإدمان .408

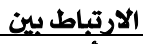
اساليب التنشئ الأسريتي والدافع بلإنجاز

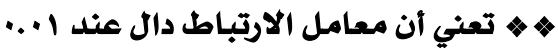

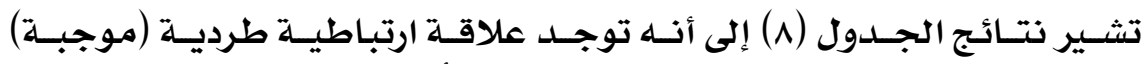

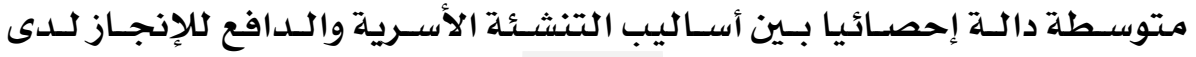




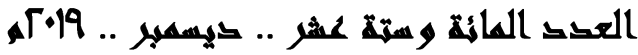

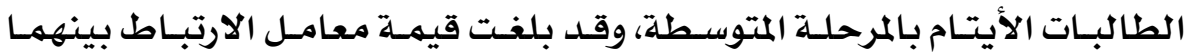

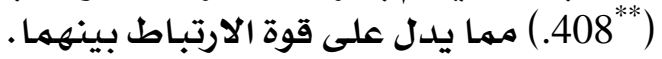

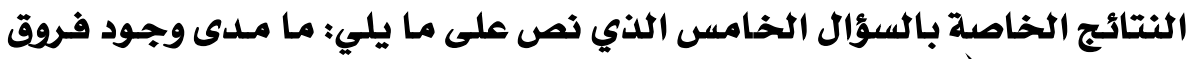

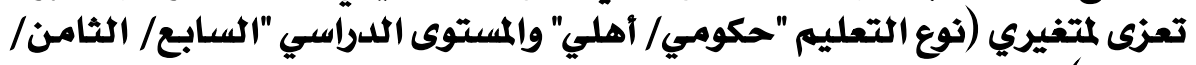

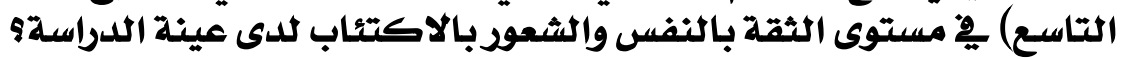

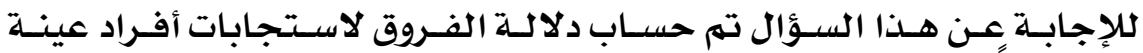

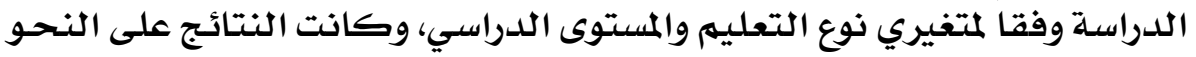
التالي: - (التراسية

النتائج الخاصة بالفروق بين استجابات أفراد العينة ملى ملدى موافتة محصوري

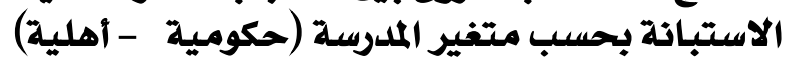

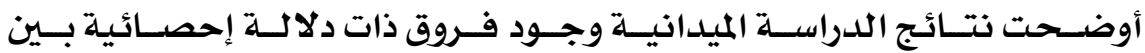

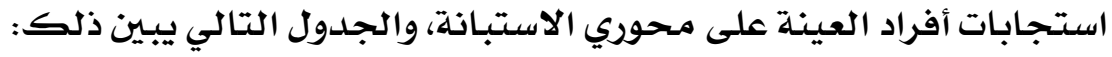

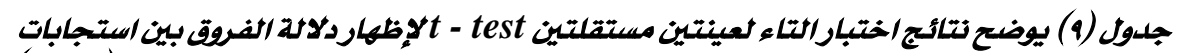

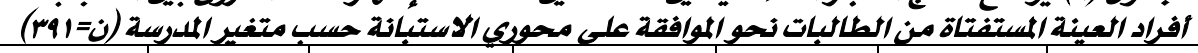

\begin{tabular}{|c|c|c|c|c|c|c|}
\hline مستوى & قيمتت & الالحيراف & المتوسط & ن & المدرست & المحور \\
\hline \multirow{2}{*}{ دالة 010} & \multirow{2}{*}{-2.596} & 8.43961 & 47.6827 & 312 & حكوميتي & \multirow{2}{*}{ الأول } \\
\hline & & 7.86508 & 50.4051 & 79 & أهليت & \\
\hline \multirow{2}{*}{ دالة 000} & \multirow{2}{*}{-4.761} & 14.83449 & 42.8429 & 312 & حكوميت & \multirow{2}{*}{ الثاني } \\
\hline & & 9.11104 & 51.1646 & 79 & أهليت & \\
\hline
\end{tabular}

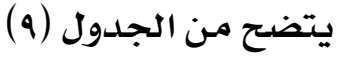

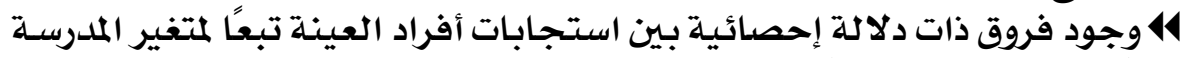

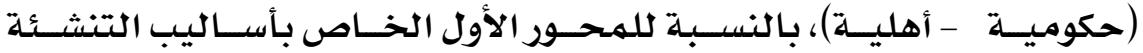

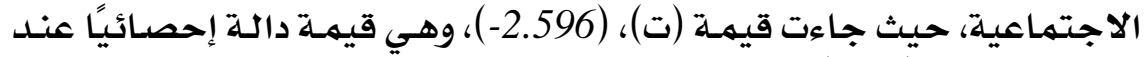

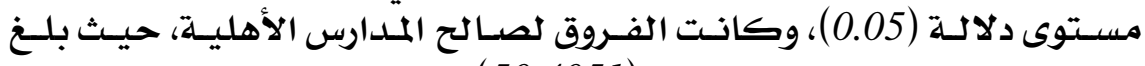

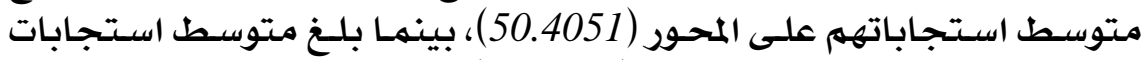

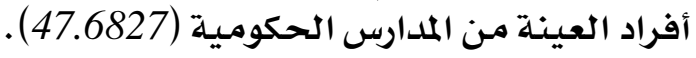

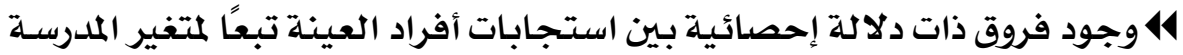

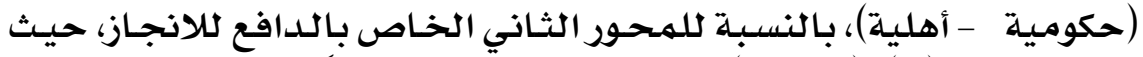

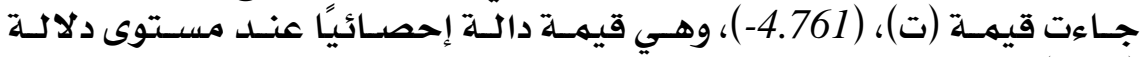

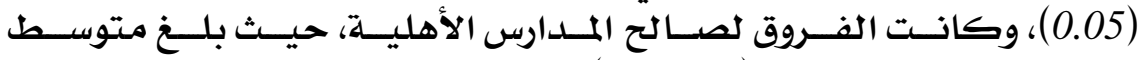

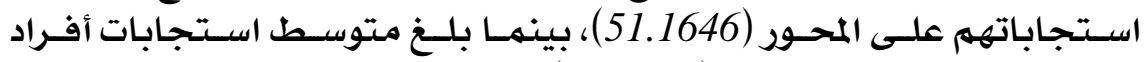
العينة من المدارس الحكوميستية (42.8429). 


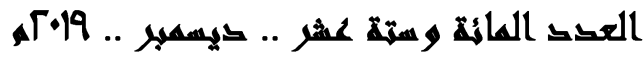

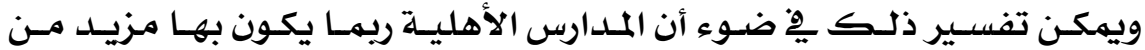

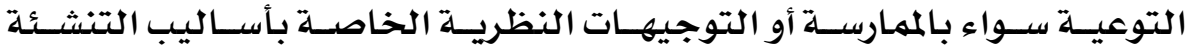

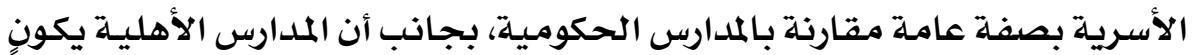

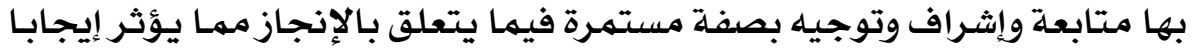

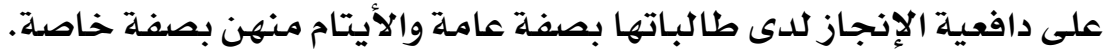

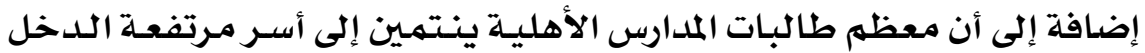

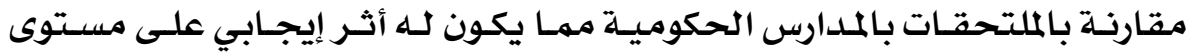

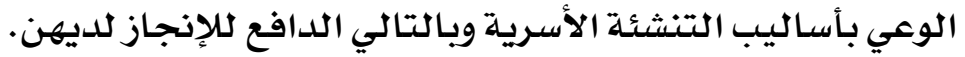

النتائج الخاصة بالفروق بين استجابات أفراد العينة على ملدى موافقة محصوري

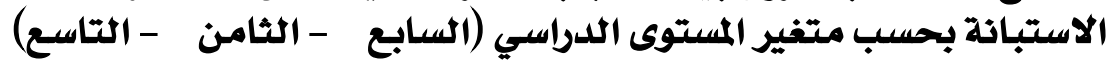

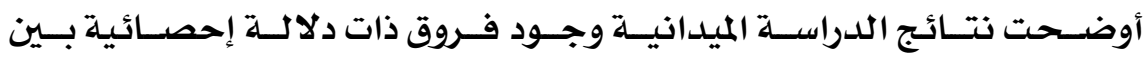

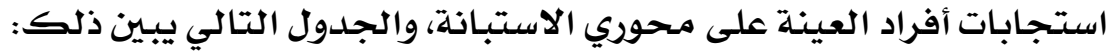

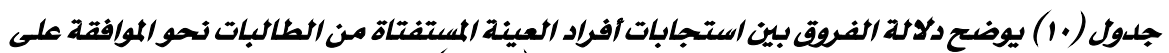
محوي الاستبانة (ن) (rq)

\begin{tabular}{|c|c|c|c|c|c|c|}
\hline مستوى & قيمت ف & 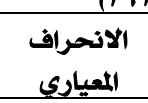 & المتوسط & ن & [اليستوى الدراسي & مالمحود \\
\hline \multirow{3}{*}{ دالت000. } & \multirow{3}{*}{ 76.747 $\square$} & 8.59098 & 41.2830 & 106 & السابع & \multirow{3}{*}{ 口الأول } \\
\hline & & 7.73185 & 48.9083 & 120 & الثامن & \\
\hline & & 5.41058 & 52.2061 & 165 & التاسـع & \\
\hline \multirow{3}{*}{ دال־000. } & \multirow{3}{*}{$13.186 \square$} & 14.14820 & 39.0000 & 106 & السابع & \multirow{3}{*}{ 口الثثاني } \\
\hline & & 14.64764 & 44.8667 & 120 & الثامن & \\
\hline & & 12.99247 & 47.8242 & 165 & التاسع & \\
\hline
\end{tabular}

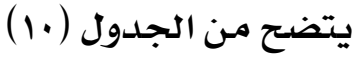

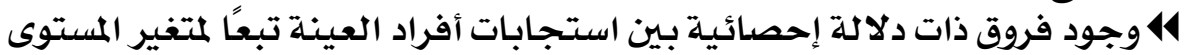

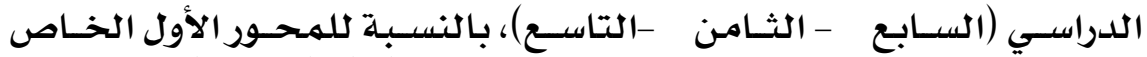

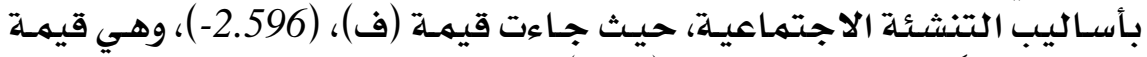

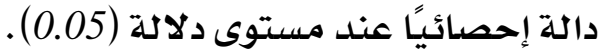

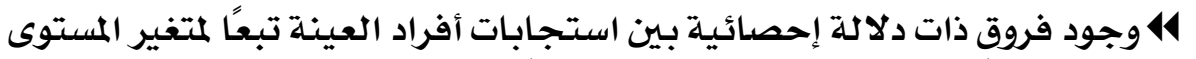

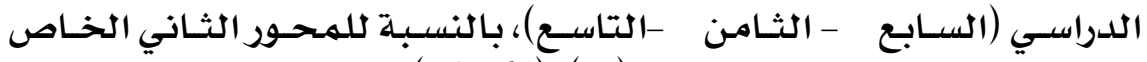

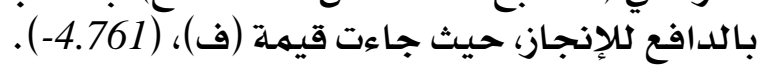

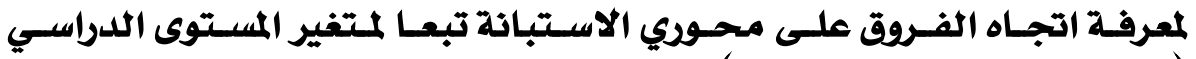

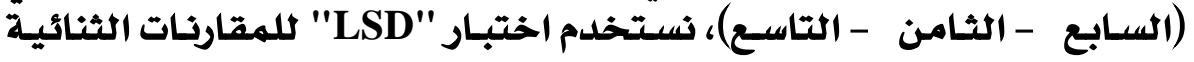
البعدية: 


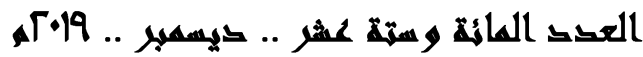

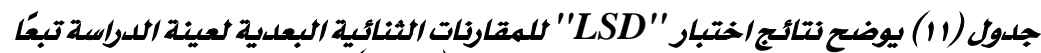

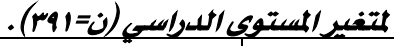

\begin{tabular}{|c|c|c|c|c|c|}
\hline الإحصائية & الخطا المعياري & 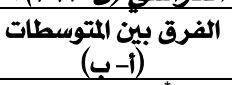 & المجموعت (ب) & المجموعت (i) & الأبعاد \\
\hline .000 & .94893 & $-7.62531^{*}$ & الثامن - الن & \multirow[b]{2}{*}{ السابع } & \multirow{6}{*}{ الأول } \\
\hline .000 & .88617 & $-10.92304^{*}$ & التاسع & & \\
\hline .000 & .94893 & $7.62531^{*}$ & السابع & \multirow{2}{*}{ الثامن } & \\
\hline .000 & .85411 & -3.29773 & التاسع & & \\
\hline .000 & .88617 & $10.92304^{*}$ & السابع & \multirow{2}{*}{ التاسع } & \\
\hline .000 & .85411 & $3.29773^{*}$ & الثامن & & \\
\hline .002 & 1.84372 & -5.86667 & الثامن & \multirow{2}{*}{ السابع } & \multirow{6}{*}{ الثاني } \\
\hline .000 & 1.72177 & -8.82424 & التاسع & & \\
\hline .002 & 1.84372 & 5.86667 & السابع & \multirow{2}{*}{ الثامن } & \\
\hline .075 & 1.65949 & -2.95758 & التاسع & & \\
\hline .000 & 1.72177 & $8.82424^{*}$ & السابع & \multirow{2}{*}{ التاسع } & \\
\hline .075 & 1.65949 & 2.95758 & الثامن & & \\
\hline
\end{tabular}

* تعني أن الفرق بين المتوسطات دالة عند مستوى معنوية 05.

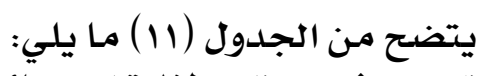

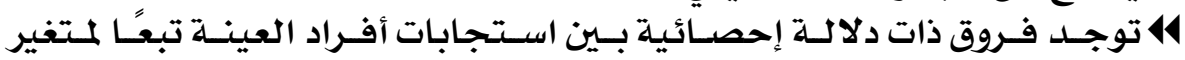

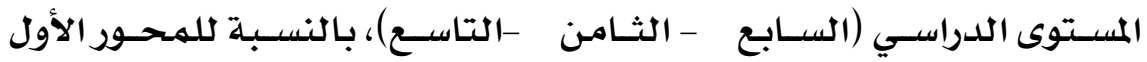

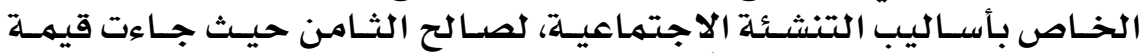

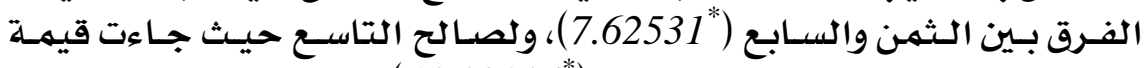

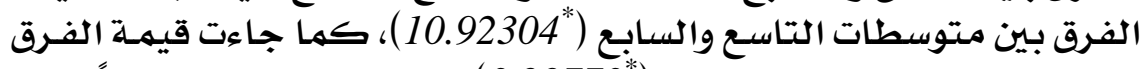

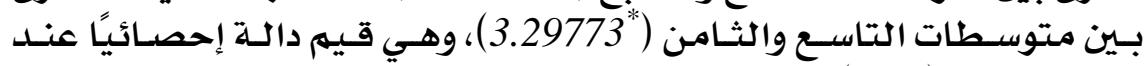
مستوى دلالة (0.05).

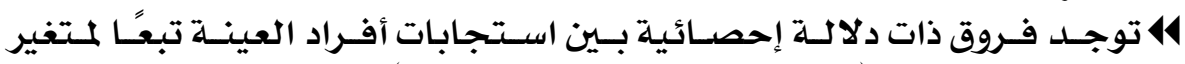

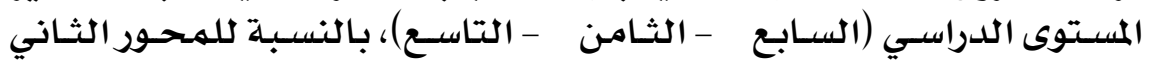

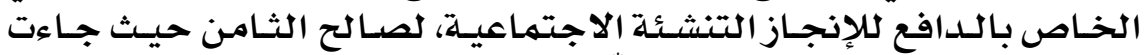

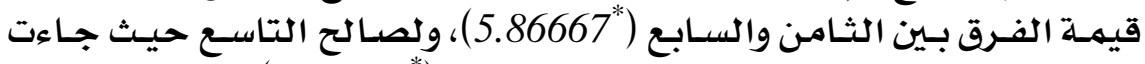

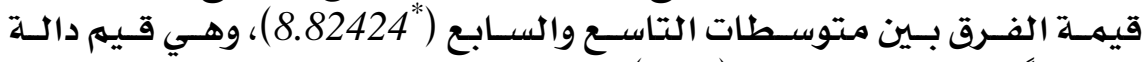

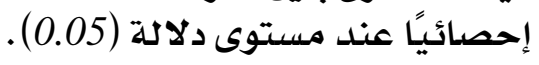

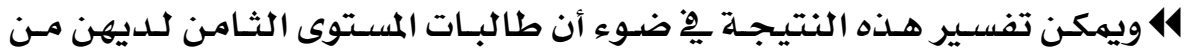

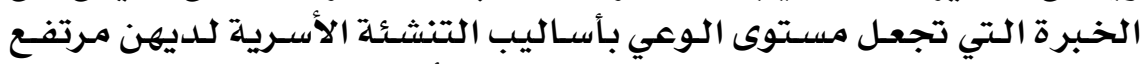

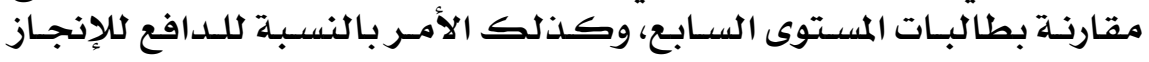

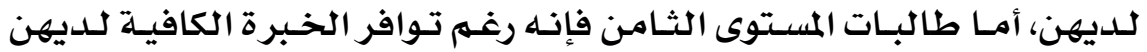

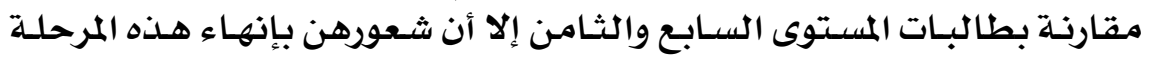

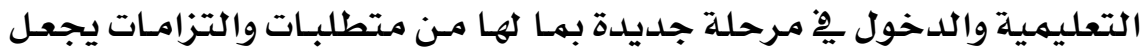

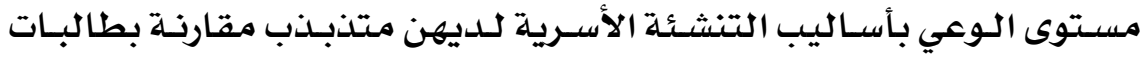

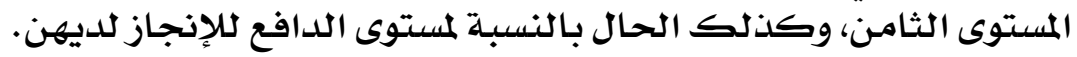




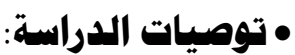

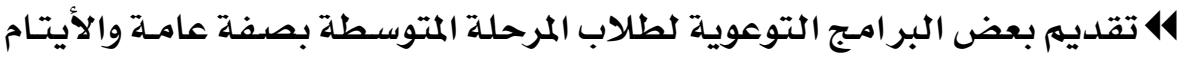

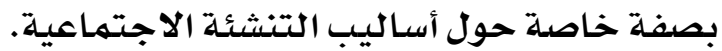

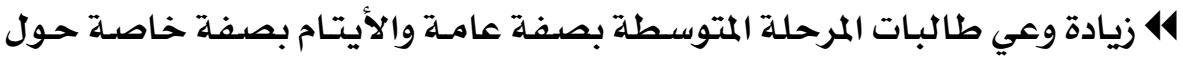

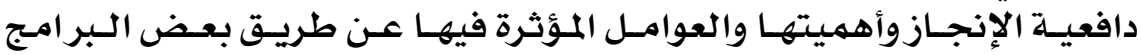

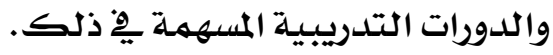

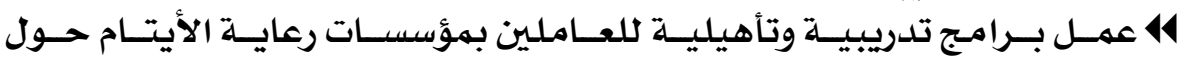
متطلباتهـم واحتياجـاتهم.

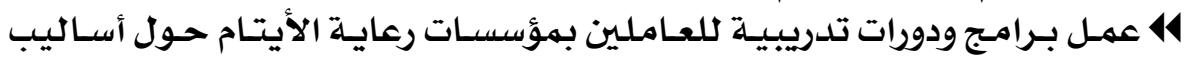

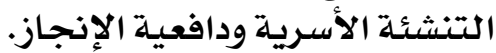

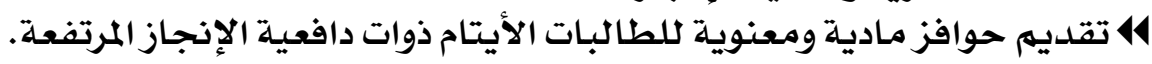
• مقترحات الدراستة:

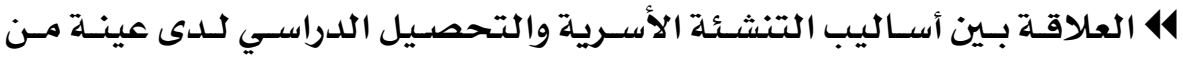

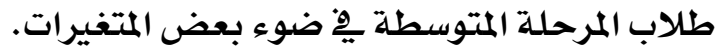

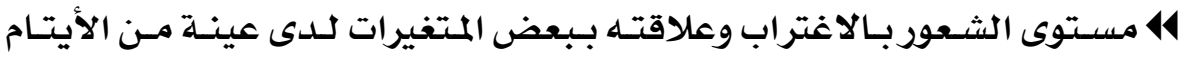
بالمرحلة المتوسطة المورئ.

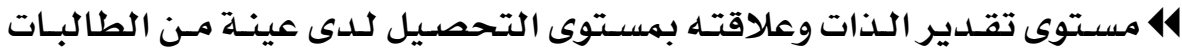

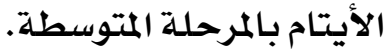

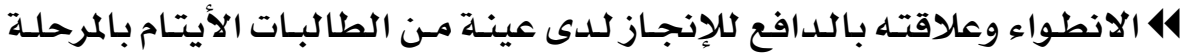

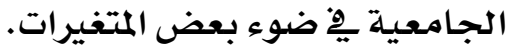

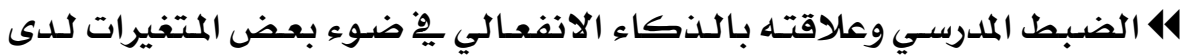
طالبات المرحلة الابتدائية.

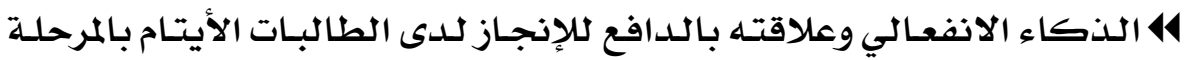
المتوسطة.

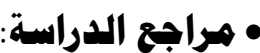

- أبو جادو، صالح. (.... r). علم النفس التربوي، عمان، دار المسيرة للنشروالتوزيع والطباعة.

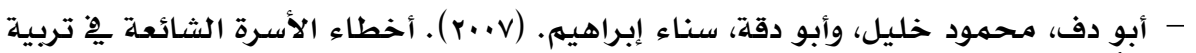

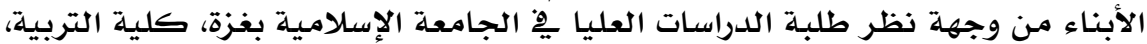

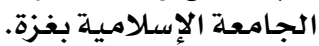

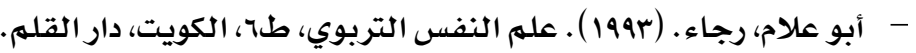

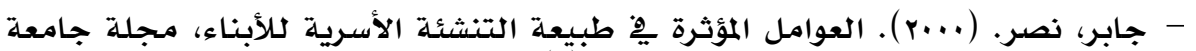

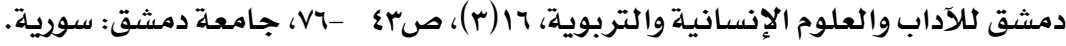

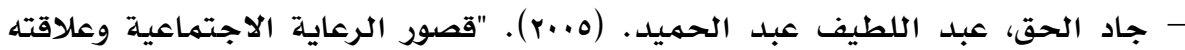

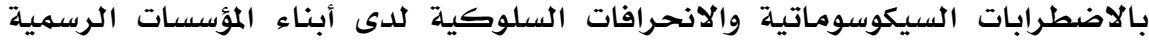

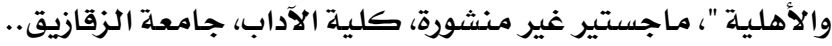

\section{\&YV}




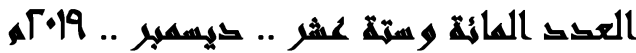

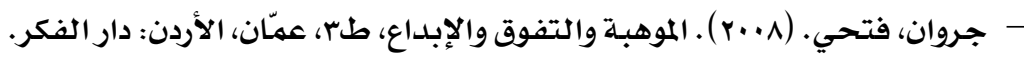

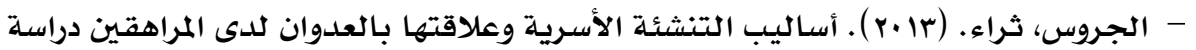

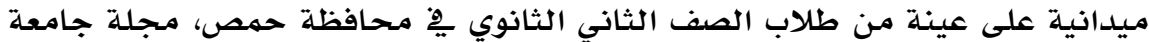

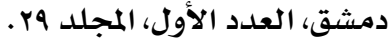

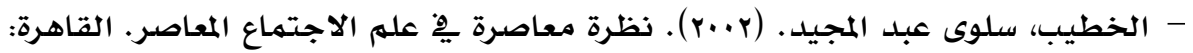
مطبعة النيل للطباعة والنشر والتوزيع.

- درويث، رمضان. (1991) . أساليب العاملة الوالدية كما يلدركها الابن الوحيد والابن

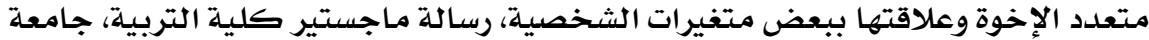
الأزهر.

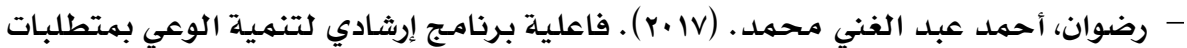

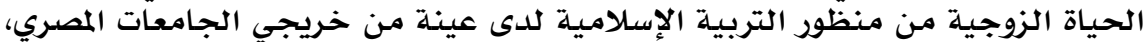

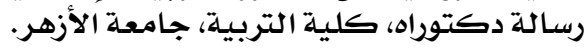

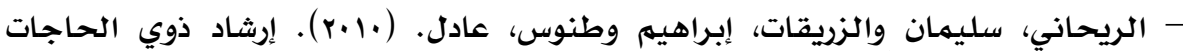

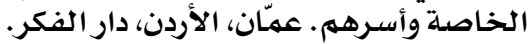

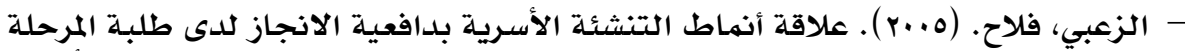

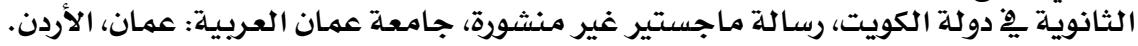

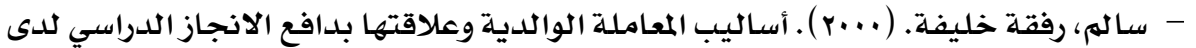

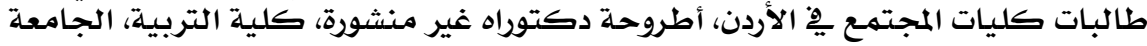
المستنصرية.

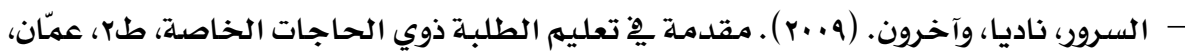
الأردن: دار الفكرو، نادوآخرو.

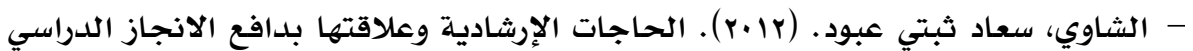

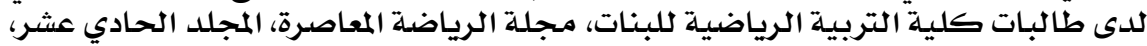
العدد السادس عشر.

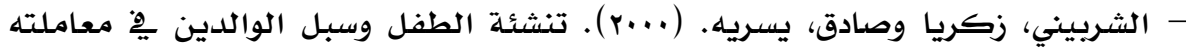

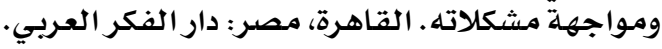

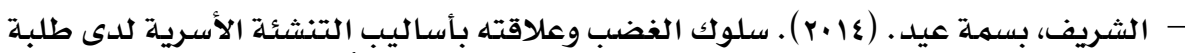

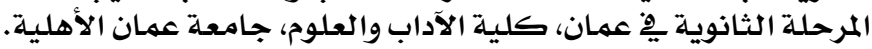

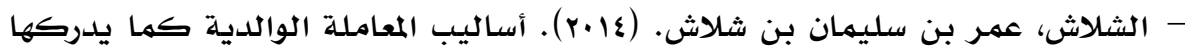

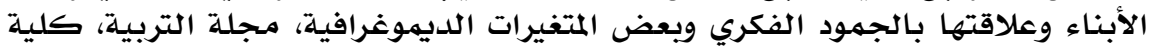

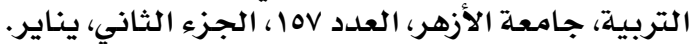

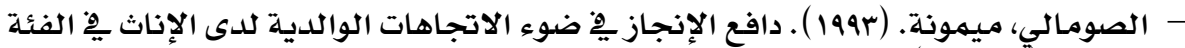

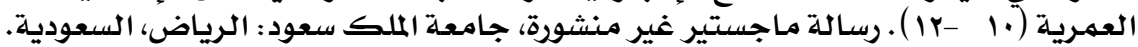

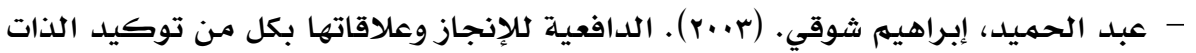

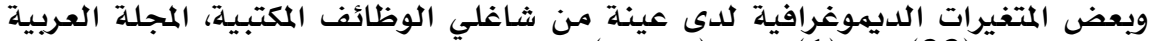

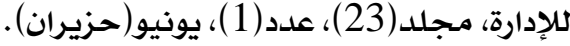




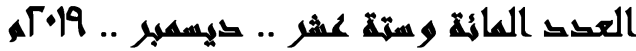

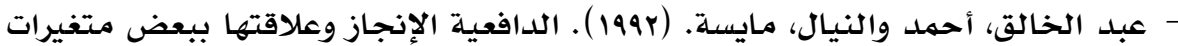

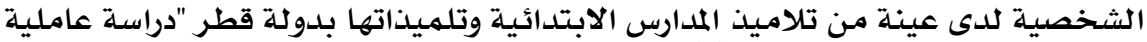

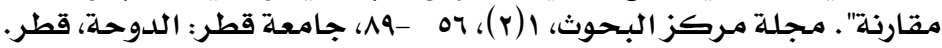

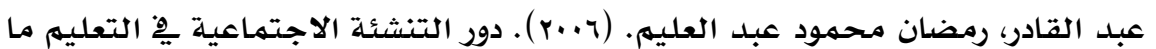

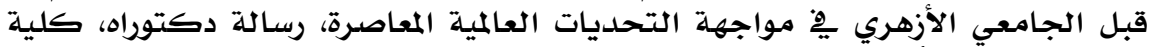
التربية، جامعة الأزهر.

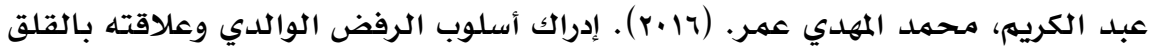

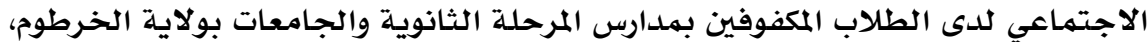
دراسات عربية يِّ التربية وعلهم النفس، العلدد الحادي والسبعون، مـارس، السعوديـة.

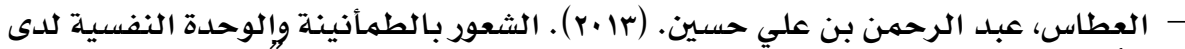

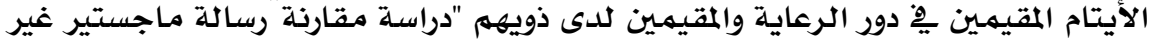

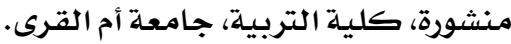

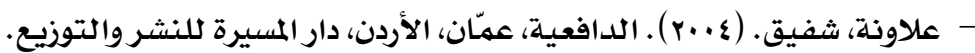

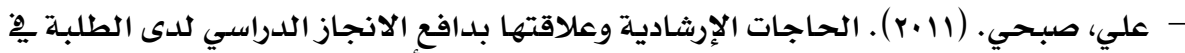

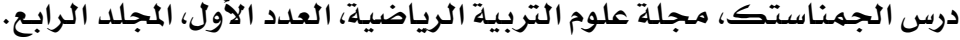
- العيسوي، عبد الرحمن. (Y.. (r). سيكولوجية التنشئة الاجتهاعية، الإسكندرية، دار الكتاب الجامعي.

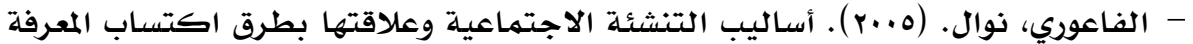

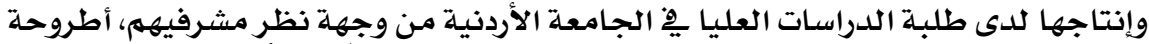
دكتوراه غير منشورة، جامعـة عمان العربية للدراسـات العليا : عمّان، الأردن.

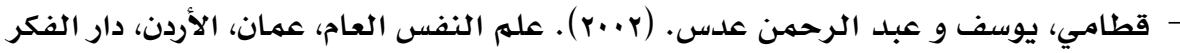
كلنشر.

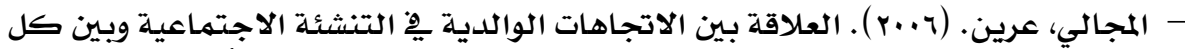

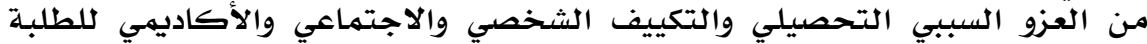

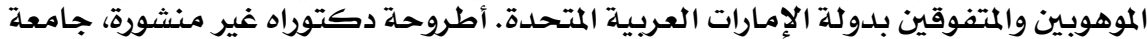

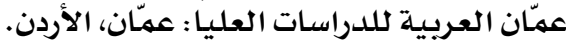

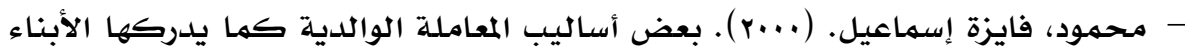

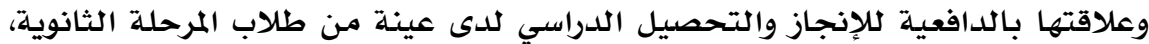

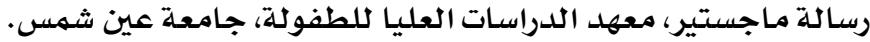

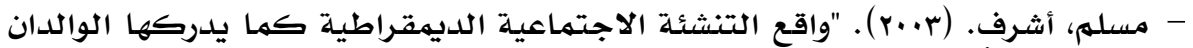

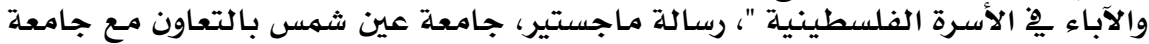
الأقصى.

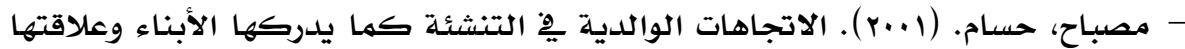

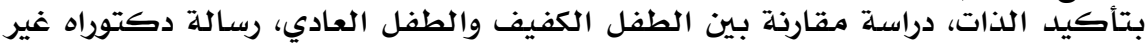

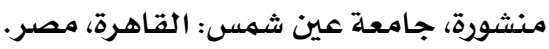

- الناقة، محمود كامل. (rا.r). تقرير عن المثاركة يف اليوم الوطني لليتيم Auteur: association lägranza pour la solidarite ledeveloppement et 


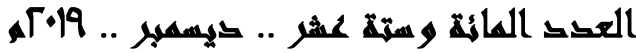

http://www.tanmia.ma/article-l'environnement imprim.php3?id_article $=10700$

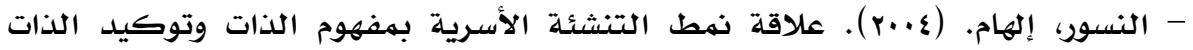

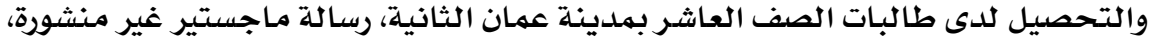

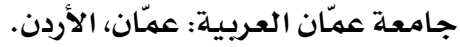

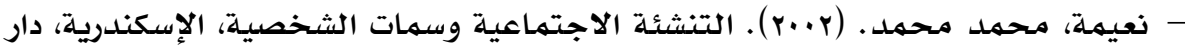

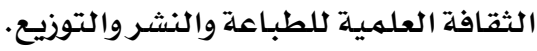

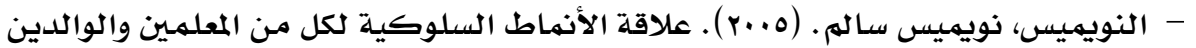

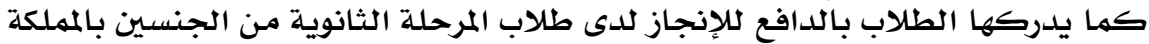

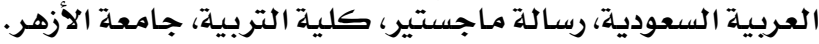

-Almajali, H.K. (2005). The influence of family upbringing styles and locus of control on the creative thinking of preparatory school learner in the United Arab Emirates. Unpublished Doctoral Theises, South Africa, Pretoria: University of South Africa.

-Azkestin \& Guven, G. (2013). Parenting styles: Parents, with 5-6 year old children. Journal of Educational and Instructional Studies in the World, 3(9): 446-463.

-Roces,C- \& Garcia, M- (2002): A Sructural equation mo-del of parental involvement, motivational and aptitudinal characteristics and academic achievment. The Journal of Experimental Education. vol. 70, No.(3) pp.257-287.

-Lehmann, R. L., (2002). Enhancing the valuing of and commitment to effortful achievement goal approach. Paper Pre pared For A E R A Annual Meeting.

-Lngoldsby B; Schvaneveldt, P.; Supple ‘A. \& Bush,K. (2004): The relationship between Parenting behaviors and ado le scent a chievement and Selfefficacy in chi le and Edcu-ador. Marriage and family Review ،35 (3-4): 139 - 159

-Lysenko, L.; Barker, E. \& Jaffee, s. (2013). Sex differences in the relationship between harsh discipline and conduct problems. Social Development, 22(1): 197-214.

-McMurtry, S. (2013). Parenting style differences in black American and White American young adults. Unpublished Dissertation, The University of Southern Mississippi.

-Miltiadou, M., \& Savenye, W. C. (2003). Applying Social cognitive Constructs of motivation to enhance student success in online distance education. Educational Technology Review, Vol. 11, No, (1), 1-20. 


\section{العكى المائة و ستمة عشر .. كيسهمبر .. 19.}

-Pelegrina, S. ; Linares, M. \& Casanova, p. (2002): Parenting styles and adolscents academic performance. Infancia y apren-dizaje, vol. 25, No.(2), pp. 147-168.

-Petri, H; and Govern, J (2004). Motivation: Theory, Research and Applications. Thomson - Wadsworth, Australia.Petri \& Govern, 2004.

-Pintrich, P. R., (2000). An achievement goal theory perspective on issues in motivation terminology, theory, and research. Contemporary Educational Psychology, 25, 92-104.

-Santrock, J. (2003). Psychology, McGraw Hill, Boston.

-Shih, S.S. (2005). Role Of Achievement Goals in Children's Learning in Taiwan. Journal of Educational Research, Vol 98, (5), 310-319.

-Sinclair, C.D. (2001). Dispositional goal orientations, Perceptions of the motivational climate and intrinsic motivation in secondary physical education: An interactionst approach. D. A. I, A. 62102, P.P. 509.

-Szymanski; Enda \& Parker, (1995).Rayen \& Deci, in Sarrazin et Trouilloud.(2006).Comment motiver les élèves a apprendre ?Les apports de la théorie de 1'auto-détermination.Paris: Dunod., p130.

-Tanaka, A; Takehara, T., \& Yamauchi, H. (2006). Achievement goals in a Presentation Task: Performance expectancy achievement goals, state anxiety and Task Performance. Learning \& Individual Differences, Vol 16 N.2, p.p. 93-99.

-White, S. A., Kavussanu, M., Tank, K. M., \& Wingate, J. M. (2004). Perceived parental beliefs about the causes of success in sport: relationship to athletes' achievement goals and personal beliefs. Scandinavian. Journal of Medicine \& Science in Sports Vol 14, (1). 57-66.

-Zwahr - Castro, J., (2000). A Structural equation model of achievement orientation effects on intrinsic motivation. D. A. I - B 6011, P. 5842.

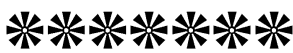


